\title{
Patterns of migration/mobility and HIV risk among female sex workers: Andhra Pradesh 2007-08
}

Niranjan Saggurti

Population Council

Ravi K. Verma

Hanimi Reddy Modugu

Saumya RamaRao

Population Council

Ajay Kumar Singh

See next page for additional authors

Follow this and additional works at: https://knowledgecommons.popcouncil.org/departments_sbsr-hiv

Part of the Demography, Population, and Ecology Commons, Family, Life Course, and Society Commons, International Public Health Commons, and the Migration Studies Commons How does access to this work benefit you? Let us know!

\section{Recommended Citation}

Saggurti, Niranjan, Ravi K. Verma, Hanimi Reddy Modugu, Saumya RamaRao, Ajay Kumar Singh, Vaishali Sharma Mahendra, and Anrudh K. Jain. 2008. "Patterns of migration/mobility and HIV risk among female sex workers: Andhra Pradesh 2007-08." New Delhi: Population Council. 


\section{Authors}

Niranjan Saggurti, Ravi K. Verma, Hanimi Reddy Modugu, Saumya RamaRao, Ajay Kumar Singh, Vaishali Sharma Mahendra, and Anrudh K. Jain 


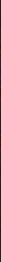

\section{PATTERNS OF \\ MIGRATION/MOBILITY \\ AND HIV RISK AMONG \\ FEMALE SEX WORKERS}

\section{Andhra Pradesh 2007-08}

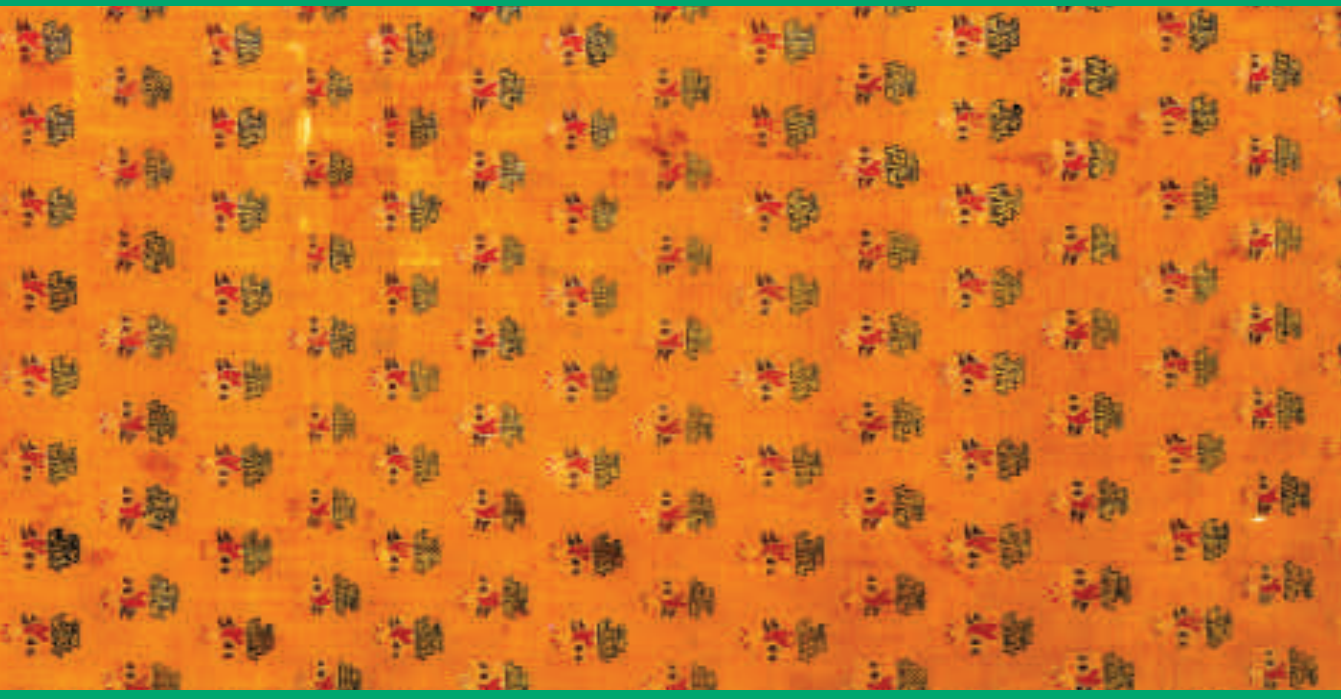

(P) Population Council 
The migration/mobility of female sex workers in search of more clients and more money has been recognized as a challenge in HIV prevention interventions in India. Little is known, however, about the patterns of migration/mobility of female sex workers in India, the facilitators and drivers of their mobility, and the implications of such mobility for the HIV pandemic. This lack of understanding has been an impediment in planning effective HIVprevention programmes for these vulnerable populations.

A research study designed to increase understanding of the patterns and factors related to migration and mobility of at-risk populations of sex workers and male migrant workers and to examine the links of migration and mobility with HIV risk was conducted in four states of India experiencing high HIV prevalence, namely Andhra Pradesh, Karnataka, Tamil Nadu, and Maharashtra. This report presents the findings from the female sex workers study on volume and patterns of mobility and their linkages with HIV risk. The field work among female sex workers in Andhra Pradesh was implemented by TNS India Private Limited and the Population Council in New Delhi.

For additional information about the study, please contact:

Dr. Saggurti Niranjan HIV and AIDS Program

Population Council India Habitat Center Lodi Road

New Delhi 110003.

Telephone: 011- 24651314

Fax: 011 - 24645060

e-mail: nsaggurti@popcouncil.org website: www.popcouncil.org
For additional copies of this report, please contact:

South and East Asia Regional Office Zone 5A, India Habitat Centre

Lodi Road

New Delhi 110003

Tel: +91 11 24642901/02

Fax: +91 1124642903

Email: vthomas@popcouncil.org website: www.popcouncil.org 


\section{(1) Population Council}

The Population Council seeks to improve the well-being and reproductive health of current and future generations around the world. The Council's biomedical, public health, and social scientists identify and evaluate responses to the most important population, health, and development issues. Work is focused on three programme areas: HIV and AIDS; Poverty, Gender, and Youth; and Reproductive Health.

\section{(C) 2008 The Population Council, Inc.}

This document may be reproduced in whole or part without permission of the Population Council, provided full source citation is given and reproduction is not for commercial purposes. 


\section{CONTRIBUTORS}

Niranjan Saggurti ${ }^{1}$

Ravi K. Verma ${ }^{2}$

Hanimi Reddy ${ }^{3}$

Saumya RamaRao ${ }^{4}$

Ajay K. Singh ${ }^{2}$

Vaishali Sharma Mahendra ${ }^{1}$

Anrudh Jain ${ }^{4}$

${ }^{1}$ Population Council, New Delhi, India

${ }^{2}$ International Center for Research on Women (ICRW), New Delhi, India

${ }^{3}$ TNS India Private Limited, New Delhi, India

${ }^{4}$ Population Council, New York, USA 


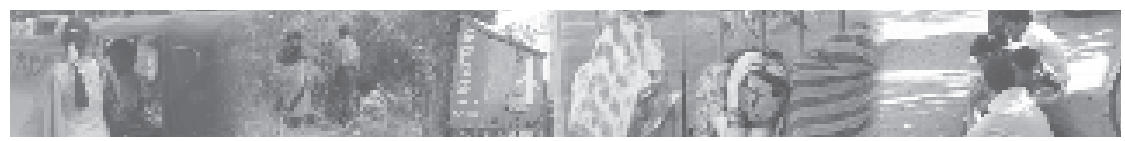

\section{FOREWORD}

In past years, considerable research has been undertaken on the role of female sex workers (FSWs) in the transmission of HIV infection. FSWs have been seen as a major 'source' of infection. Consequently, they have been extensively targeted to prevent its spread, There is, however, a gap in our understanding of the dynamics of sex work, sex workers' patterns of mobility and the relationship of such mobility with risk to HIV infection and gender-based violence.

During November, 2006 - November, 2007, the Population Council undertook a study to examine the patterns of mobility of FSWs and to study its links with HIV risk. The goal was to provide research-based evidence to inform the formulation of policies and to improve the implementation of programs. The study was conducted in 22 districts in four high HIV prevalence states namely Maharashtra, Karnataka, Tamil Nadu and Andhra Pradesh. It was undertaken in collaboration with the Karnataka Health Promotion Trust, the TNS India Private Limited and the GFK-MODE Private Limited.

Ethnographic and survey research methods were employed to collect data on FSWs' patterns and routes of mobility, and the condom use behaviors of over 5500 mobile female sex workers. Support provided by Avahan, Avahan's partner NGOs, the National AIDS Control Organisation, State AIDS Control Societies, other international and national organizations, and most importantly by the study participants themselves, was invaluable in undertaking this study.

The study shows that on average, mobile FSWs moved to four different locations for sex work in the two years prior to the survey. Sixty percent of the FSWs sampled for the survey reported that they had moved to atleast two different locations and that they had moved to atleast one location outside the district in the one in which they lived. There was greater mobility of sex workers in Andhra Pradesh and Karnataka than in Maharashtra and Tamil Nadu. In Andhra Pradesh and Maharashtra, greater mobility showed associations with a consistent decrease in condom use; increased exposure to sexually transmitted infections; and increased perceived risk of HIV. It is likely that since FSWs move to maximize trade opportunities, they use less discretion in using condoms when they are mobile. In Karnataka and Tamil Nadu, however, mobility was not associated with condom use. 


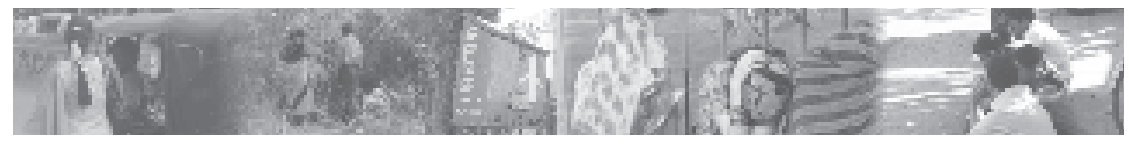

In places where FSWs had the opportunity to get more clients and where transaction time was short for example during Jataras (Pilgrimages), consistent condom use declined sharply in all for states where the study was conducted. About three-fourths of the mobile FSWs who visited places of jatara for sex work did not use condoms consistently. Thus, their vulnerability and risk to infection was enhanced in these situations. These findings indicate the need to design interventions that can be effectively implemented in places of Jatara and other such places.

Over three-fourths of the mobile FSWs, in the study were 19 to 34 years of age. Most were illiterate; many were in debt; and the majority belonged to lower castes such as Dommara, Madigra, Harijana, Devadasi, Kalavanthulu and Lambani. Most of these women were either vidowed, divorced or separated. More then two-fourths worked as domestic servants, vendors, agricultural laborers or construction laborers. The study showed that a large majority ofthe mobile FSWs suffered gender-based violence. Mobile FSWs who faced violence, were in debt, and/or were widowed, separated or divorced were less likely to use condoms. These results underscore the importance of designing program interventions for these specially disadvantaged, vulnerable subpopulations of FSWs.

The study mapped specific districts where mobile FSWs were conconcentrated. Clearly, those districts need special attention. Social support systems in these districts should be strengthened. Strategies should be designed to bring mobile FSWs within the ambit of the program. In addition, district-specific interventions should be designed and implemented to address the needs of these highly vulnerable sub-populations of FSWs.

FSWs have been traditionally categorized by place of work -- in brothels, roadsides, highways, dhabas, homes, railway stations and bus stands, and interventions are targeted to these pre-defined categories of sex workers. Our study, however, shows that mobile FSWs solicit clients in multiple places. And although hotels and lodges are most commonly used, they have sex with their clients, in a number of different places. These findings suggest the need to target interventions at places where significant numbers of FSWs can be reached. 


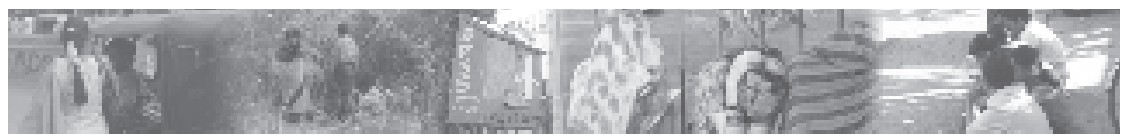

This pioneering research study provides important evidence that should be used at both the national and state levels for the design and implementation of program strategies for the prevention of HIV infection among FSWs and their clients. This information should be used by the national and state-level AIDS control organizations to inform the design of policies and the implementation of government programs. These research findings are also relevant for the large numbers of NGOs and others engaged in programs targeting FSWs and their clients. Thus, there are a number of stakeholders who could utilize the findings of this wide-scale research study for the prevention and control of HIV and AIDS.

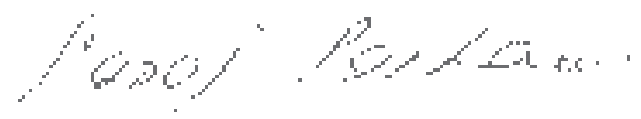

Dr. Saroj Pachauri MD, PhD.

Regional Director

South and East Asia

Population Council 


\section{Table of Contents}

Acknowledgements

Executive Summary 1

I. BACKGROUND AND OBJECTIVES 5

II. STUDY DESIGN AND METHODS 7

2.1 Identification of study areas

2.2 Characteristics of study areas

2.3 Quantitative survey

2.4 Sample size and sampling design

2.5 Degree of mobility

III. VOLUME AND PATTERNS OF MOBILITY

$3.1 \quad$ Volume of mobility

3.2 Patterns of mobility

IV. PROFILE OF MOBILE FEMALE SEX WORKERS

4.1 Socio-economic and demographic profile

4.2 Sources of income

4.3 Debt

4.4 Reasons for entry into sex work

4.5 Life style characteristics

4.6 Autonomy

4.7 Physical violence

4.8 Exposure to mass media and NGOs

V. HIV RISK AMONG MOBILE FEMALE SEX WORKERS

$5.1 \quad$ Type of partners

$5.2 \quad$ Consistent condom use with type of partners

5.3 Consistent condom use with type of partners by district

5.4 Self-reported STI symptoms

5.5 Perception of HIV risk

5.6 Ability to use condoms and actual condom use

5.7 Socio-economic insecurity and HIV

5.8 Mobility and HIV risk

VI. IMPLICATIONS FOR HIV PREVENTION PROGRAMMES ACCORDING TO PLACE OF SOLICITATION AND SEX

6.1 Places of solicitation and places of sex

6.2 Strategies to reach mobile female sex workers in HIV prevention programmes 


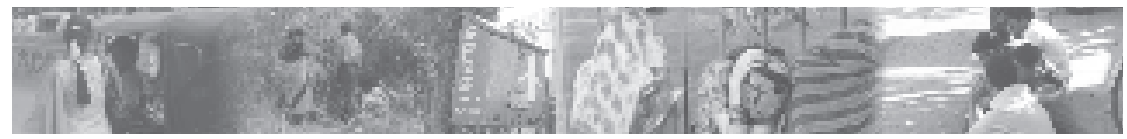

\section{List of Figures/Maps}

Map 1. Study Districts in Andhra Pradesh

Figure 1. Mobility of female sex workers by numbers of moves

Figure 2. Mobility of female sex workers by district

Figure 3. Percent of mobile female sex workers by age group

Figure 4. Volume of mobility by age and by place of contact

Map 2. Mobility routes of female sex workers currently in Hyderabad urban district

Map 3. Mobility routes of female sex workers currently in Krishna district

Map 4. Mobility routes of female sex workers currently in Guntur district

Map 5. Mobility routes of female sex workers currently in East Godavari district

Map 6. Mobility routes of female sex workers currently in Kurnool district

Figure 5. Seasonal migration of mobile female sex workers in Krishna district

Figure 6. Marital status of mobile female sex workers by district

Figure 7. Mobile female sex workers by source of income

Figure 8. Percent of mobile female sex workers having debt of various amounts

Figure 9. Reasons for entry into sex work

Figure 10. Percent of mobile female sex workers who reported use of alcohol in the month prior to survey

Figure 11. Percent of mobile female sex workers who reported having a cell phone

Figure 12. Percent of mobile female sex workers who experienced physical violence at least once in the past year

Figure 13. Percent of mobile female sex workers who reported watching television in the past month

Figure 14. Percent of mobile female sex workers who reported having sex with types of partners in the week prior to the survey 


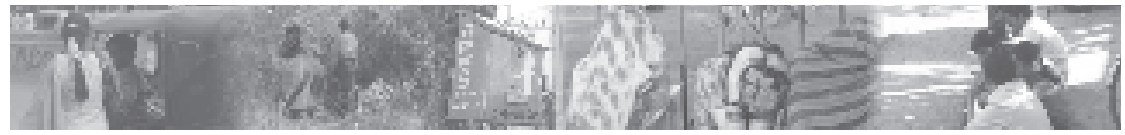

Figure 15. Percent of mobile female sex workers who reported consistent condom use by type of clients

Figure 16. Percent of mobile female sex workers who reported consistent condom use by type of client/partner by district

Figure 17. Percent of mobile female sex workers who reported STI symptoms, and who continued sex while having STIs

Figure 18. Percent of mobile female sex workers who reported consistent condom use with different partners by marital status

Figure 19. Percent of mobile female sex workers who reported condom use with different clients by degree of mobility

Figure 20. Percent of mobile female sex workers who reported places of solicitation for clients

Figure 21. Percent of mobile female sex workers who reported places where they have sex with clients

Figure 22. Percent of mobile female sex workers who reported places where they either solicit clients or have sex

Figure 23. Anticipated HIV programme coverage of mobile female sex workers, if programme is implemented in following places

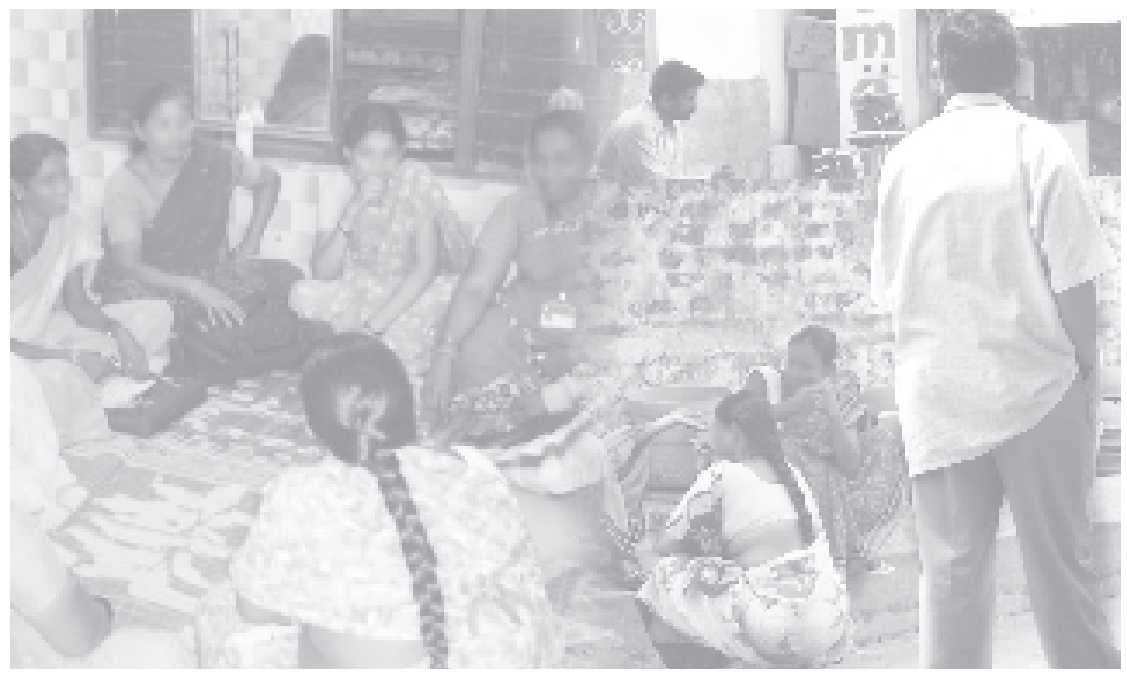




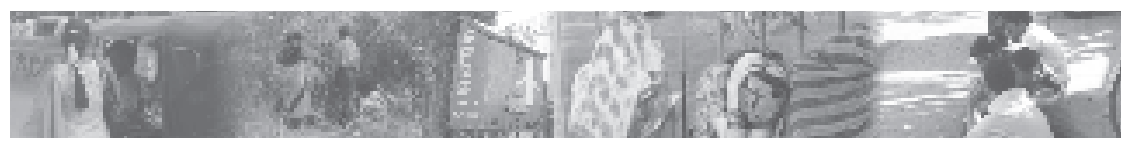

\section{ACKNOWLADGRMINIS}

The study on Migration/Mobility and HIV

Risk among Female Sex Workers was successfully completed during 2007-08. The efforts of a number of individuals who were involved in the study are acknowledged.

First of all, we are grateful to the Bill \& Melinda Gates Foundation for its support for the study through Avahan, its India AIDS Initiative. We are particularly thankful to Mr. Ashok Alexander, Dr. Gina Dallabetta, Dr. Aparajita Bhalla, Mr. Hari Menon, and Ms. Jayanti Rajagopalan, from the Avahan, it's India AIDS initiative of the Bill \& Melinda Gates Foundation for their active support and involvement at all stages of the project. However, the views expressed herein are those of the authors and do not necessarily reflect the official policy or position of the Bill \& Melinda Gates Foundation and Avahan.

We would like to acknowledge the support of the members of the Technical Advisory Committee (TAC) for their overall guidance in the smooth conduct of the study. The contributions of the members: Dr. Prem Saxena, Dr. P. M. Kulkarni, Dr. Tarun K. Roy, Dr. R. R. Gangakhedkar, Dr. Rohini Pande, Dr. Gurumurthy Rangaiyan, Dr. Arvind Pandey, Dr. Rajatashuvra Adhikary, Dr. Shiva S. Halli, Dr. Tobi Saidel, and Dr. Shalini Bharat were helpful both through their direct involvement in TAC meetings and through interactions with individual members during the various stages of the project. Special thanks are due to Dr. Saroj Pachauri for chairing the Technical Advisory Committee and for guiding us at each stage of the project.

We acknowledge the contribution and support of the research team at the International Center for Research on Women (ICRW) for their review of and feedback on the study report.

We thank all of the experts who participated in a series of workshops that were organized to prepare qualitative research tools; undertake training of the research teams; plan qualitative data analysis; and prepare questionnaires, the sample design, and the tabulation plan for the report.

We are grateful to our consultants Dr. Pertti J. Pelto, Senior Anthropologist, Ms. Lakshmi Ramachandar, and Mr. Zaheer Ahmad Khan for their assistance. 


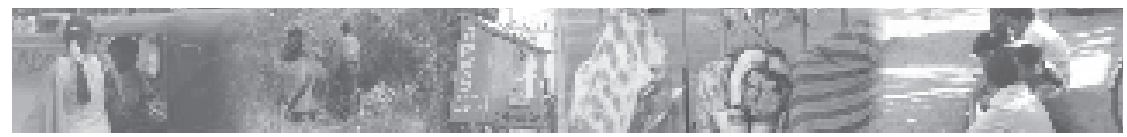

Special thanks to Mr. V. L. Thomas, Executive Assistant at the Population Council, for his administrative support throughout the study and his expert assistance in creating the tables and graphs and for formatting the report.

We convey our special thanks to Dr. Ajay K. Khera, Mr. Aslam Naved, and Ms. Lakshmi Murthy from the National AIDS Control Organization (NACO), Mr. Ashok Kumar, Project Director from the Andhra Pradesh State AIDS Control Society (APSACS), the authorities and programme staff of the Hindustan Latex Family Planning Promotion Trust (HLFPPT), Technical Support Unit (TSU), India HIV/AIDS Alliance, Population Services International (PSI), CARE India, for their help in facilitating data collection and interpretation.

We acknowledge the contribution of Dr. U.V. Somayajulu, Dr. H. Sridevi, Mr. Seshagiri Rao, Mr. Pavan Kumar for their interest and hard work in implementation of the study. We also thank all the research investigators individually for their efforts in gathering data.

Most important, we are especially grateful to the participants in this study who have, without hesitation, given their time and narrated their experiences and views regarding their mobility and vulnerability to HIV risk.

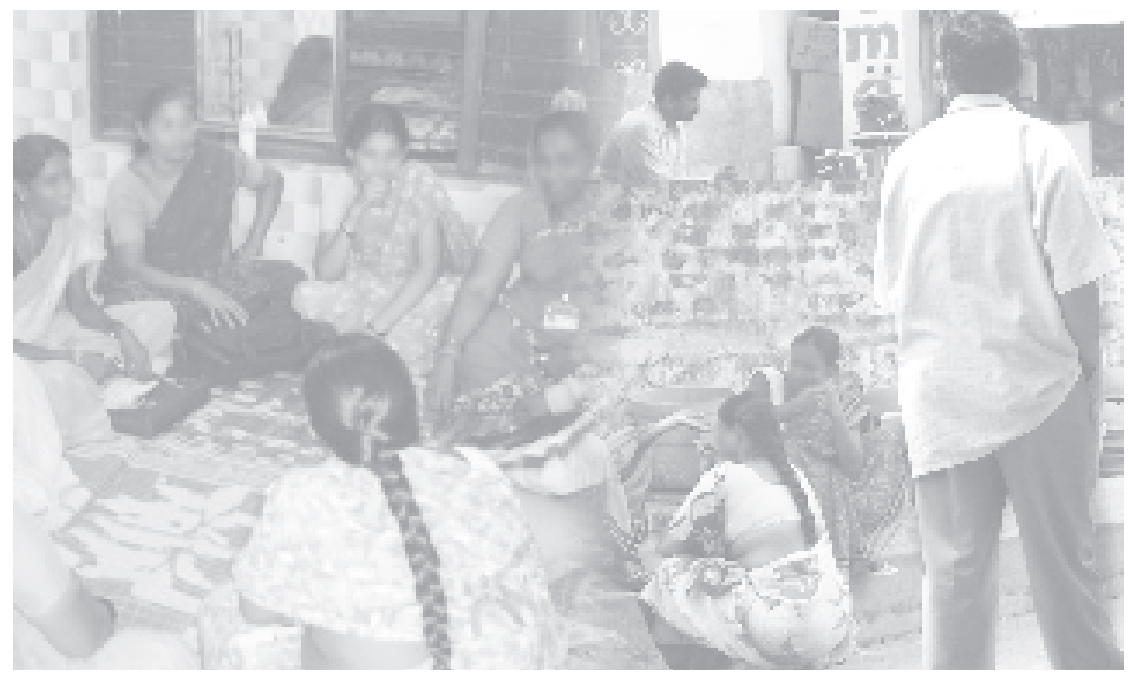




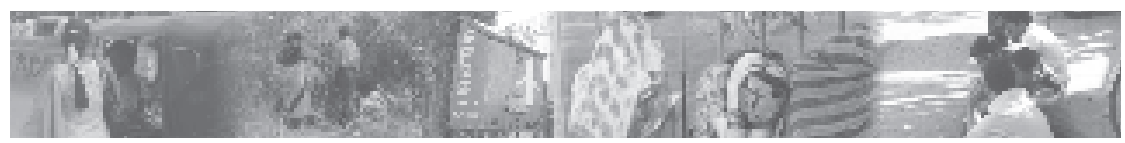

EXECUTIVE SUMMARY
High HIV prevalence among both the adult population and mobile female sex workers in Andhra Pradesh has serious implications for the spread of the HIV epidemic. At present, we know very little about the patterns of movement of various at-risk populations and the nature and extent of interaction among

them. An understanding of why some forms of mobility are related to increased HIV transmission is necessary in order to design intervention programmes to reduce risk behaviour of mobile populations, particularly for those who are at a high risk of infection, including sex workers.

The present study was undertaken to answer some of the questions on mobility and migration of female sex workers in Andhra Pradesh as they relate to the HIV epidemic. Specifically the study was undertaken with the following objectives:

- To assess the volume and patterns of mobility of female sex workers.

- To describe the characteristics of mobile female sex workers.

- To examine the determinants of HIV risk among female sex workers, with particular emphasis on mobility-related characteristics.

The cross-sectional study involved collection of qualitative and quantitative data to identify and characterize destination points and interviews with sex workers to examine mobility patterns and associated vulnerabilities to HIV. Five major destination points selected for the study were East Godavari, Guntur, Hyderabad, Krishna, and Kurnool. These sites were characterized using a variety of ethnographic methods, including key informant interviews, in-depth interviews, and mobility maps drawn by female sex workers. The district-level descriptions helped to identify small and large sex worker sites, including brothels and places of solicitation such as roads, highways, bus stands, railway stations, and market areas. A total of 2,247 sex workers were screened in the survey, of which 1,536 were eligible given that they were aged 18 years and older and had moved to at least one place in the last year. 


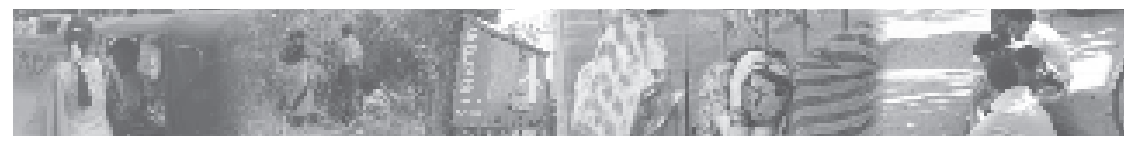

Eighty percent of female sex workers are in the age group of 25-39 years, 45 percent are illiterate, and the mean years of education among literate mobile female sex workers is six years. A little more than half of the sex workers in Andhra were divorced/widowed/separated. In most instances, it was the husband who had left the woman as he was involved in an extramarital relationship. There were also some women who had left their husband mainly because of violence and the husband's extramarital relationships. About 40 percent of sex workers earn money through a combination of sex work and sexrelated work such as commissions from referring clients and renting room for sex. Among the rest, in addition to sex work they earn their income from other occupational sources such as daily wage work, petty business, selling flowers or vegetables, paan shop, contract work, ironing, and drama and dance groups.

When the female sex workers were asked about their reasons for entering sex work, the majority (82 percent) mentioned 'economic conditions'. Their poor economic situation was often the result of being left destitute by the death of parents or husband and after divorce/separation or husband's ill-health. More than one-third of sex workers reported they entered sex work because of 'debt' in their place of origin. Between 11 and 18 percent of females in different districts entered this profession by their own choice, while 1-5 percent in different districts entered sex work by force.

A large proportion (88 percent) of sex workers had moved at least twice in the last two years. On average, female sex workers made four moves in the past two years for sex work purposes. Mobility is highest among sex workers aged 25 years or older. More than one-third of female sex workers from all the districts had visited Jatara locations in the last 12 months and the majority went to Jatara locations in groups.

The association between degree of mobility and the indicators of HIV risk was also examined. The percentage of mobile female sex workers reporting consistent condom use ranged from 52 percent to 72 percent. A high proportion of mobile female sex workers (67 percent to 79 percent) reported that they had at least one of the eight STI symptoms at least once in the past six months. A little more than one-fourth of the mobile female sex workers continued to have sex even after having STI symptoms. One-third of mobile female sex workers from Andhra Pradesh had experienced physical violence (beating/hitting /thrown out of the house) in the last year. A major source of physical violence 


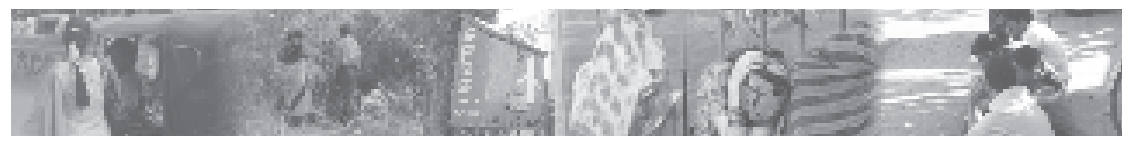

was women's clients. Among those who experienced physical violence, consistent condom use is lower and reporting of STI symptoms and selfperceived risk of HIV infection are higher. Between 17 percent and 30 percent of mobile female sex workers did not use condoms at the time they experienced sexual violence.

Analyses of condom use by type of client indicate that 84 percent of mobile female sex workers used condoms consistently with occasional clients, while the percentage declines for regular clients (72 percent) and for non-paying partners (46 percent). Consistent condom use is significantly lower among mobile female sex workers who also earn income from other occupations than among those who are completely dependent on sex work. This suggests a need for strengthening programmes for those mobile female sex workers who earn income from other occupations.

A significantly lower proportion of mobile female sex workers used condoms consistently with clients when they visited/stayed in 5+ places (59 percent) in the last two years as compared to those who visited/stayed in just 2 places (74 percent). Consistent condom use with occasional clients also declined as the number of places sex workers stayed/visited increased. Similarly, consistent condom use is lower among those sex workers who visited Jatara locations alone for sex work. About one-third of sex workers who visited Jatara locations have not used condoms consistently in those locations. In summary, female sex workers' risk for acquiring HIV as measured by inconsistent condom use, reported STI symptoms, and high self-perception of HIV risk increases with their degree of mobility, irrespective of their place of contact with clients.

To target such highly mobile female sex workers in intervention programmes, a comprehensive understanding of their places of solicitation and sex is needed. Mobile female sex workers solicit clients at multiple places, such as road side areas, railway stations, bus stands, market areas, hotels or lodges, and own homes. A significant proportion of mobile female sex workers reported that they solicit clients over the phone. Similarly, mobile female sex workers have sex in multiple places with clients, including rented rooms, hotels, lodges, own home, clients' home, and road side. 


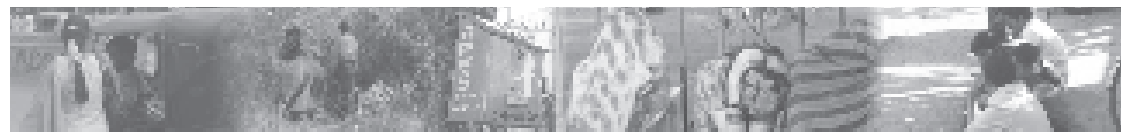

Female sex workers who move frequently to different places and who visit other areas for a short time are at greater risk of HIV, and special efforts are needed in HIV prevention programmes to address the needs of such sex workers. Mobile female sex workers visit to Jatara locations, who face violence, and who are currently in debt and widowed/separated are the most vulnerable and need special attention in HIV prevention programmes.

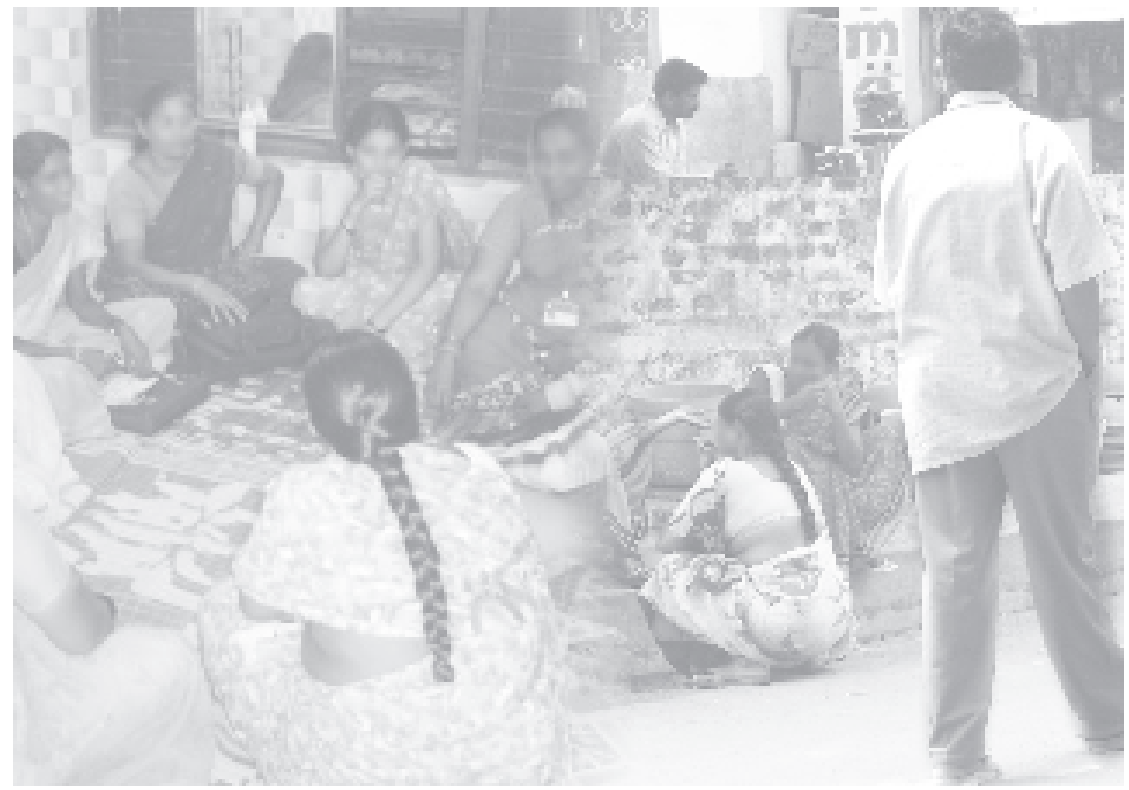




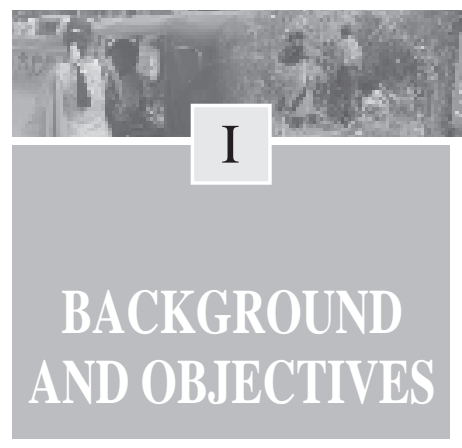

According to the National Family Health Survey round three (NFHS-3) Andhra Pradesh is one of the non-hilly states in India that recorded the high HIV prevalence among adults in the general population $(0.75$ percent for women, 1.22 percent for men, and 0.97 percent overall), whereas the prevalence among female sex workers in selected districts of the state ranged from 8 to 26 percent. High HIV prevalence among both the adult population and female sex workers in Andhra Pradesh has serious implications for the spread of the epidemic. Andhra Pradesh is also believed to have a high level of sex worker trafficking despite being the only state in India with an anti-trafficking policy ${ }^{1}$ Andhra Pradesh accounts approximately 15 percent of the sex workers who operate in more than twelve states and territories across the country, 80 percent in Goa, 45 percent in Delhi and 28 percent in Mumbai ${ }^{2}$-and the state accounts for the majority of females aged 12-35 in the red light districts in Delhi, Mumbai, Kolkata, and Goa ${ }^{3}$.

The India AIDS Initiative, the Avahan Programme supported by the Bill and Melinda Gates Foundation, has placed special emphasis on female sex workers to check the spread of the HIV/AIDS epidemic. At present, however, we know very little about the patterns of movement of various at-risk populations and the nature and extent of interaction among them. An understanding of why some forms of mobility are related to increased HIV transmission is necessary in order to design intervention programmes to reduce risk behaviour of mobile populations, particularly for those who are at a high risk of infection, including sex workers.

\footnotetext{
${ }^{1}$ Dirghangi, Amrita, "The Political, Social and Health Implications of trafficking of Women and Children in India", Justice and Peace Studies, May 2005.

${ }^{2}$ Jafri, Syed Amin, "Andhra Tops in Trafficking in Females," Based on Survey

Conducted by Prajwala, Shattered Innocence, September 19, 2002.

${ }^{3}$ Menon, Meena, "Women in India's Trafficking Belt," TWN Third World Network.
} 


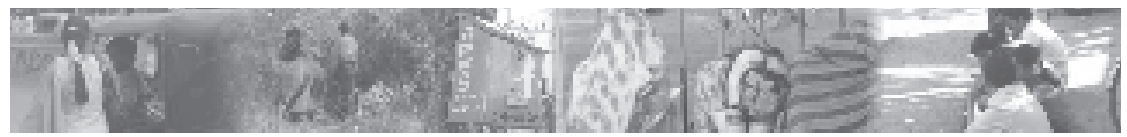

The present study was undertaken by the Population Council to answer some of the questions on mobility and migration of female sex workers in Andhra Pradesh as they relate to the HIV epidemic. Some of the key questions that the present study has addressed are: What is the volume of female sex workers in any given area that are mobile? What are their various destinations and where do they originate from? What is the frequency and seasonality of this mobility/migration? What are the routes of mobility/migration and duration of stay in each place? What is the nature and volume of sex work through this route? Is there a connection between their place of origin and their choice of a particular destination? What are the individual, community, and structural factors that determine their movements and mobility? And how does mobility influence HIV vulnerability and risk?

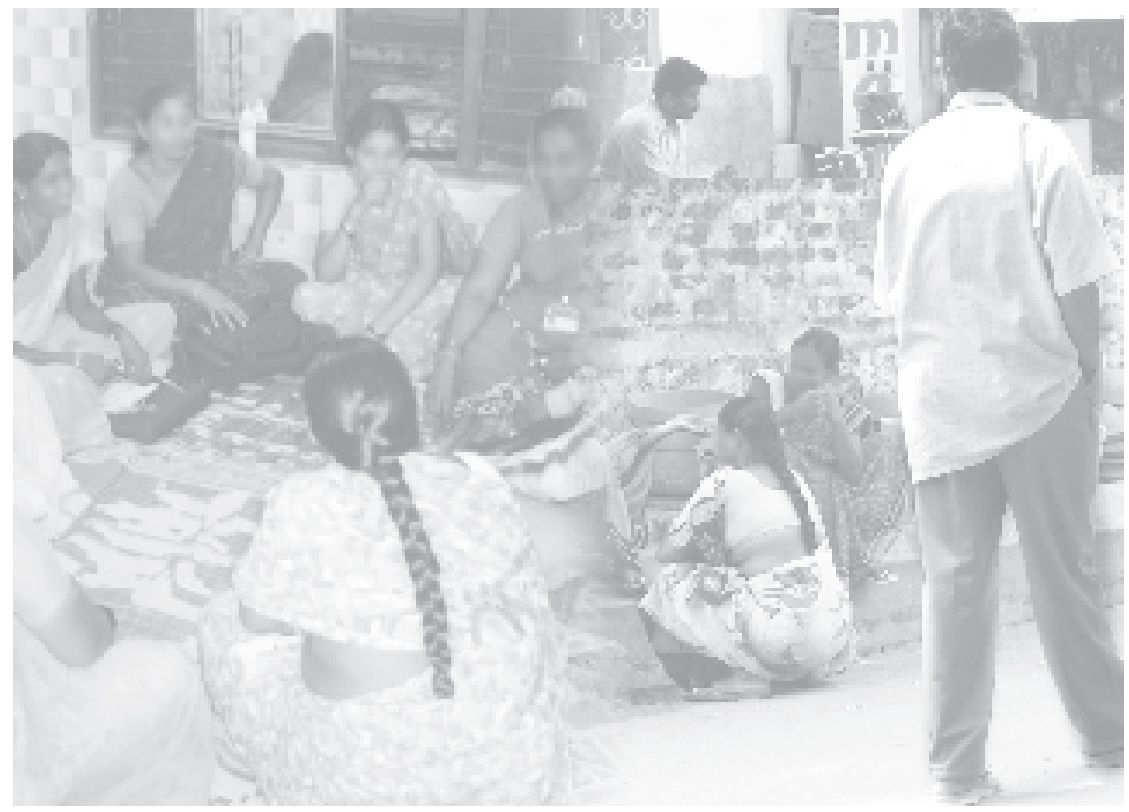




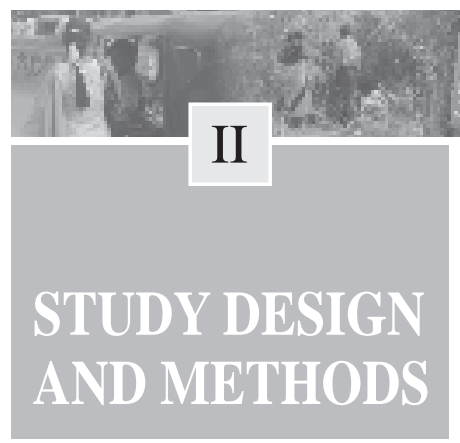

The cross-sectional study design involved the following major steps and engaged both qualitative and quantitative methods as outlined below:

1 Identification of major destination points, including intermediate destination points of concentrations of female sex workers

2 Characterisation of destination points, including intermediate destination points using qualitative research methods; and

3 Gathering of quantitative data at the destination, including intermediate destination points.

The field work was carried out during November 2006 through July 2007. Major destination points (also referred to as 'study areas' in the report) were identified and characterized using primarily qualitative data followed by quantitative survey.

\subsection{Identification of study areas}

Major destination and intermediate points were identified using mapping data on female sex workers and by relying on key informant interviews from state and district health and AIDS programme officials in Andhra Pradesh and Avahan programme personnel and partners. The top five major destination points of female sex workers selected were East Godavari, Krishna, Guntur, Hyderabad, and Kurnool. They were initially referred to as destinations points because of the large concentration of female sex workers in these areas. From the mobility patterns of female sex workers, however, and from the key informant interviews it became apparent that the selected destination points constituted part of the migration route and therefore served as both 'destinations' and 'intermediate destinations' for the mobile female sex workers at different points in time. In this report therefore these points are referred to as destinations or intermediate destinations as appropriate. 


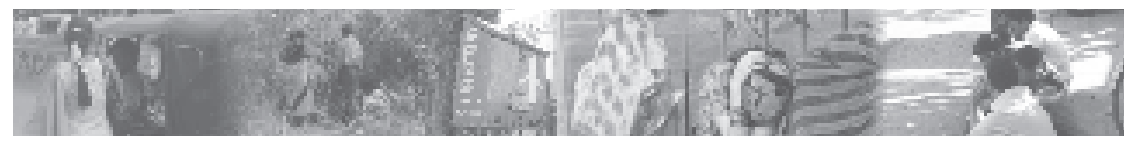

\section{Map 1 : Study Districts in Andhra Pradesh}

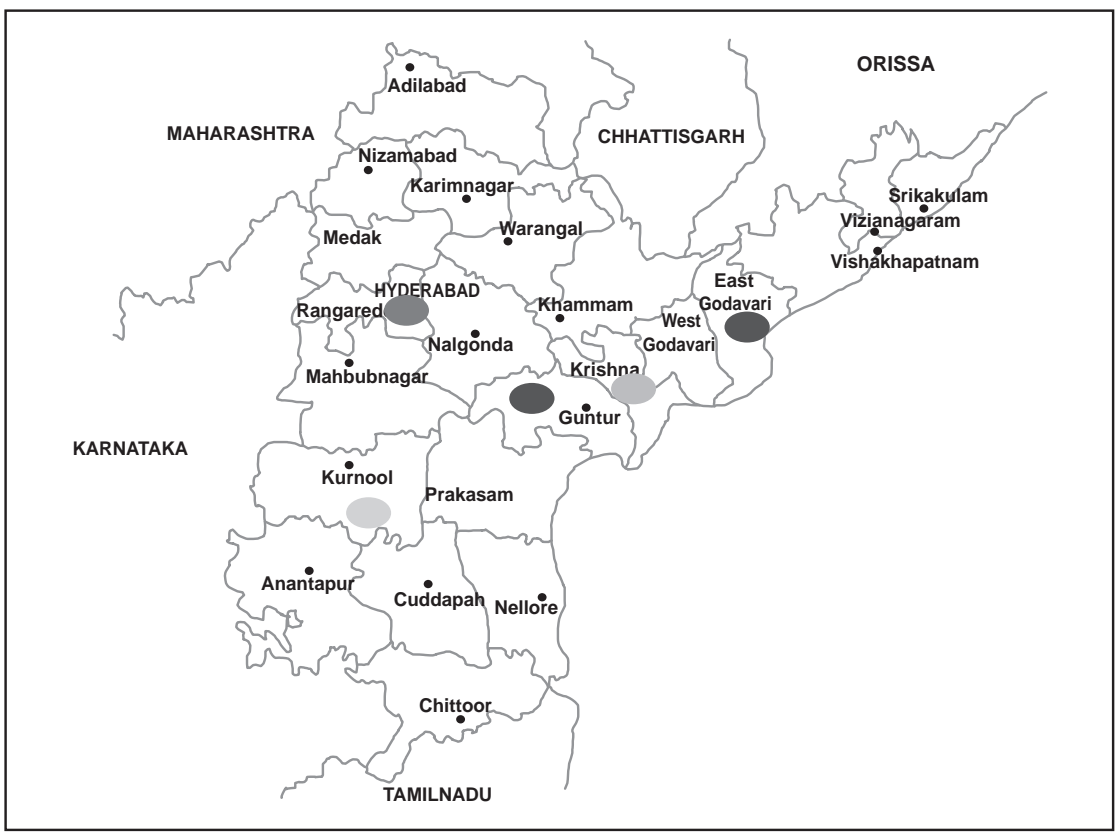

It is perhaps not a coincidence that selected destination points of female sex workers also happen to be major hubs of economic activities in Andhra Pradesh. For example, East Godavari is well known for exporting of kaolin and fire clay minerals; Vijayawada in Krishna district has a rail and road transport centre serving the entire country; Guntur is a key agricultural production and export centre; and Hyderabad, the capital of the state, has some of the most expansive information technology and infrastructure-related activities in the country.

The field research started with a description of selected districts. The purpose was to map sites within each district where female sex workers operated, estimate the number working at each site, the types of female sex workers (brothel, street, highway, home), the estimated proportion who are mobile and their places of origin, presence of male migrant workers at the site, existence of HIV programmes, proximity to highways, and the local economy of the site. 


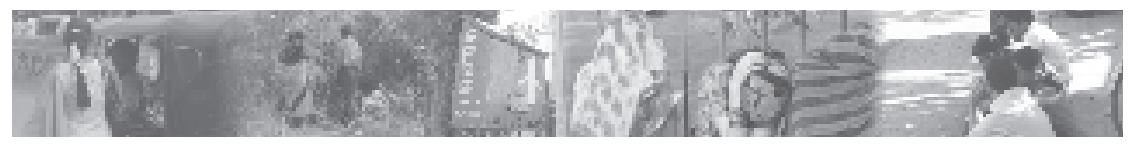

Discussions were held with district-level administrators, NGO heads, chief district medical officers, doctors from STI clinics, police officials, and heads of professional associations. In addition, at each site interviews were conducted with individuals knowledgeable about the sex work industry such as dalaals (brokers), paan shop wallas, rickshaw pullers, auto drivers, lodge owners and staff, workers in cinema theatres, brothel owners, female sex worker peer leaders, and NGO staff.

The district-level descriptions helped to identify 126 small and large sex worker sites and included brothel areas and soliciting places such as roads, highways, bus stands, railway stations, and market areas. These lists of sites were used to select primary sampling units (PSUs) with each PSU covering an estimated 500 female sex workers. PSUs were formed by combining small areas or by segmenting the large areas such that each PSU has approximately 500 female sex workers. Fifty-six PSUs were formed, of which 15 were selected randomly for the sampling frame.

\subsection{Characterization of study areas}

Study areas were then characterized with the help of qualitative data using ethnographic methods, including key informant interviews, in-depth interviews, and mobility maps drawn by female sex workers. The purpose of the characterization was twofold: 1) to identify individual, community, and structural factors which determine the mobility of female sex workers and also influence their risk and vulnerabilities; and 2) to inform the selection of primary sampling units for the quantitative survey. A total of 310 interviews (142 key informant interviews and 168 in-depth interviews) were carried out in the selected five study areas. All interviews were conducted with purposive selection of respondents following informed consent procedures.

The qualitative interviews were carried out in three stages. In the first stage, interviews were held with local key informants including female sex workers to map physical locations for solicitation of clients and to develop a profile of mobile female sex workers and their mobility patterns. In the second stage, indepth interviews were conducted with selected female sex workers to generate individual mobility maps; and interviews were held with groups of sex workers to describe group dynamics and group mobility.

The qualitative data was gathered by a team of 12 experienced and specially trained investigators ( 7 females, 5 males). The information from key 


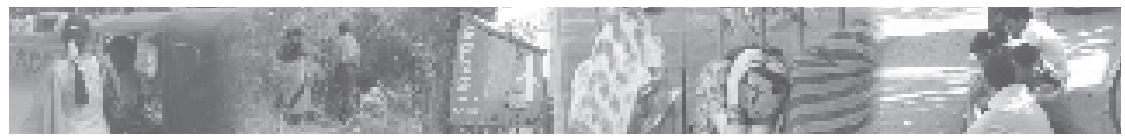

informants, in-depth interviews, and mobility maps were collected in Telugu (state language for Andhra Pradesh). These interviews were translated into English and analysed with the help of Atlas.ti, a computer-based text-search programme.

\subsection{Quantitative survey}

The purpose of the quantitative survey was to provide an estimate on the prevalence of mobility among female sex workers and to identify the relationship between mobility-related factors and HIV risk behaviour. For the purposes of the survey a female sex worker was defined as "mobile" and included in the study if she

a) Had been in a sex work for at least one year

b) Had visited two or more places for the purpose of sex work excluding the current location in the past two years; and

c) One of those moves/visits was made across the district.

The study was confined to female sex workers of age 18 years and above.

\subsection{Sample size and Sampling design}

Power calculations based on $30 \%$ non-consistent condom use among female sex workers indicated a sample of 200 mobile sex workers interviews was sufficiently powerful for determining non-consistent condom use and associated risk factors including degree of mobility. Assuming half of the randomly selected female sex workers mobile, in each district, between 300 and 400 female sex workers were targeted in the survey.

A total of 2,247 sex workers were screened in the survey, of which 1,536 were eligible satisfying the inclusion criteria described above. Thus, 68 percent of all the female sex workers interviewed were mobile in Andhra Pradesh.

In each PSU within each district, the study adopted two types of sampling procedures for selecting brothel-based and non-brothel-based sex workers because of the differences in how sex work is practiced: two-stage systematic sampling and time location sampling procedures. 


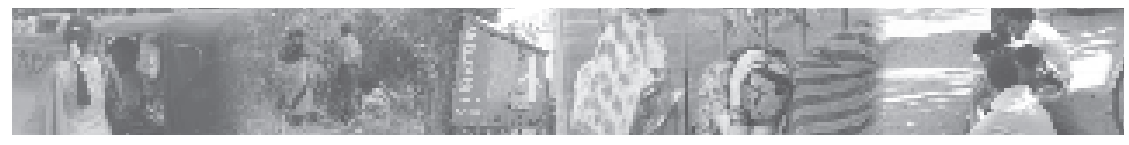

For selection of sex workers in brothel-based areas, a two-stage systematic sampling procedure was used. Firstly, the lanes/small pockets/areas within each larger brothel site were listed. Using the probability proportional to size procedure, the number of brothel houses to be selected in each large brothel area was pre-determined. After fixing the number of sex workers to be interviewed from each selected lane, the sub-lanes or small areas were selected systematically from the lists as first-stage sampling. In the second-stage sampling, brothel houses were systematically selected with the first house being randomly selected and subsequent houses selected based on a calculated interval. One sex worker from each selected brothel house was interviewed using a screening tool.

For selection of sex workers in non-brothel-based areas, a time location sampling procedure was used. The social maps prepared during qualitative research formed the basis for the selection of these sex workers. From the social maps of each area, locations of smaller sites were listed. After listing of the sites from social maps, the key informants and NGO staff were contacted again to identify the peak days and times for the sex workers' visit to the sites. Thus for each area, a list was prepared which detailed times when sex workers would be available. Time slots were fixed for the interviewers to visit the site. Interviewers then went to each of those sites and waited for sex workers. Sex workers who came to the site at the defined times were selected for interview using a screening tool.

Screening interviews collected information on sex workers' age, place of contact, district where the interview was conducted, number of places they ever visited for sex work, number of places they visited in the last two years for sex work, and number of districts they visited in the last two years. This information helped to identify the mobile female sex workers according to the study criteria and estimate the volume of mobility among representative sex workers at the district level.

The survey instrument administered to eligible sex workers included: socioeconomic and demographic profile, living conditions, media exposure, life style, support services, migration/mobility pattern and sex work history, Jatara (religious carnival)/event-related mobility for sex work, seasonal mobility, connectivity with place of origin, client profile, experience of violence, availability and access to condoms and ability to use them, condom use in current and previous places, sexually transmitted infections, knowledge and risk perception related to HIV/AIDS. 


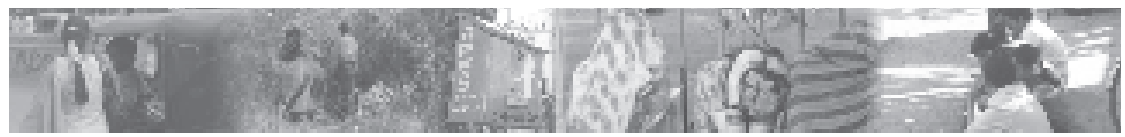

Quantitative surveys in all study areas were carried out with the help of personal digital assistants (PDAs) by ten trained and experienced interviewers ( 8 females, 2 males). Interviewers were specially trained in the ethical conduct of interviews on sensitive issues and with marginalized populations. Informed consent was obtained from the respondents and personal information was stored in safe places without identifiers. Data quality was ensured through a supervisory structure that provided regular feedback in the field and also ensured data cleaning in the office and, if needed, a revisit to the field. Data processing operations carried out for survey data included loading of the data onto a laptop on a daily basis, up-loading of weekly collected data to the Population Council data base, data quality checks, feedback to the field team, cleaning, and tabulation. Statistical Package for Social Sciences (SPSS) was used for data consistency checks and analysis.

\section{$2.5 \quad$ Degree of mobility}

We constructed an index to classify female sex workers on a continuum of mobility ranging from least to most mobile. The indicators of mobility used in the study are: total number of places sex worker visited/stayed in the last two years (2 places, 3-4 places, 5+ places); the number of districts visited/stayed in the last two years (1-2 districts, $3+$ districts); sex worker visits to Jatara locations (No, Yes - went alone, Yes - went in group).

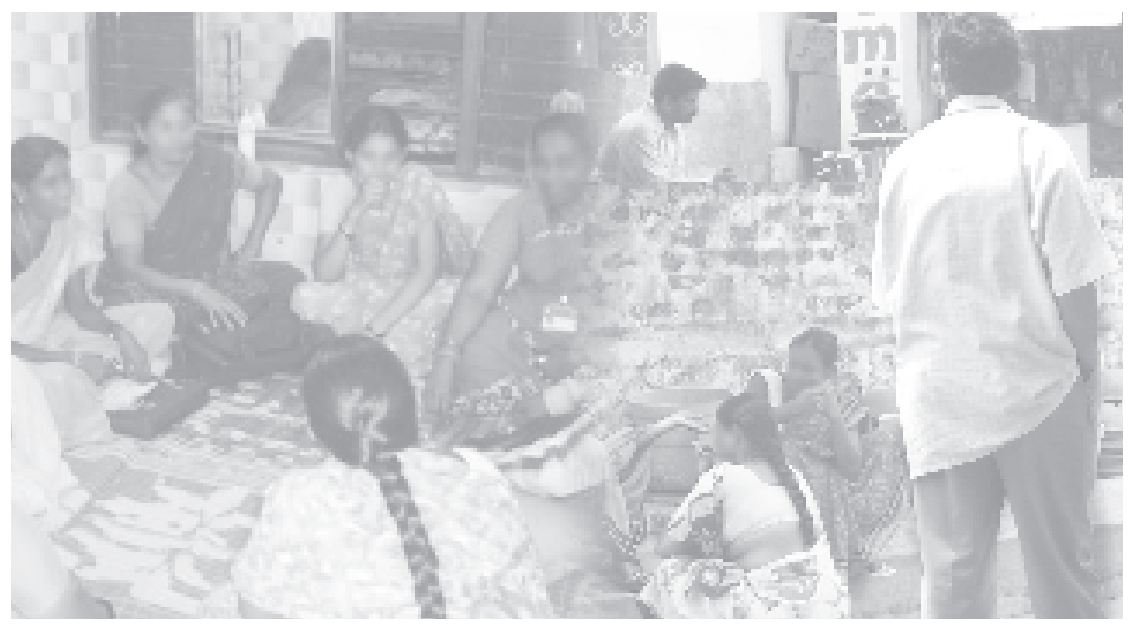




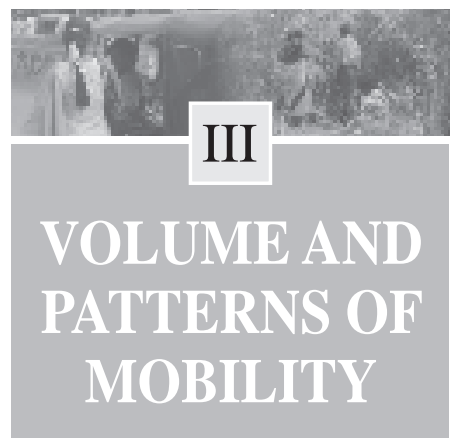

\subsection{Volume of mobility}

The data indicate that 93 percent of sex workers interviewed had moved at least once for sex work in the last two years, and 88 percent had moved at least twice. More than two-thirds of the female sex workers ( 71 percent) had moved at least once across the district.

Figure 1. Mobility of female sex workers by number of moves

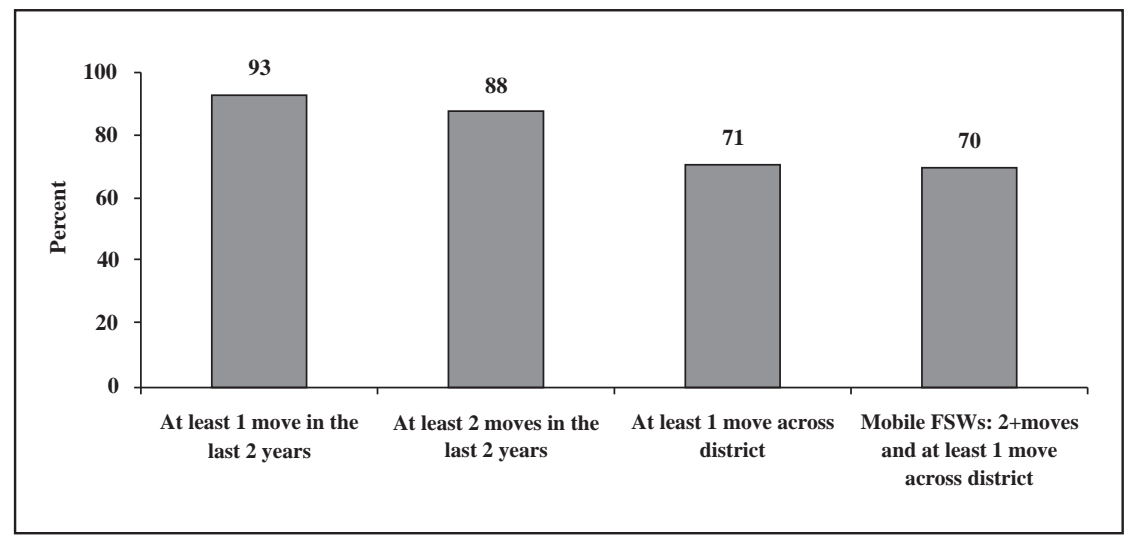

On average, female sex workers made four moves in the past two years for sexwork purposes, and on average 2.7 of these moves were made across the district (see Table 1). 


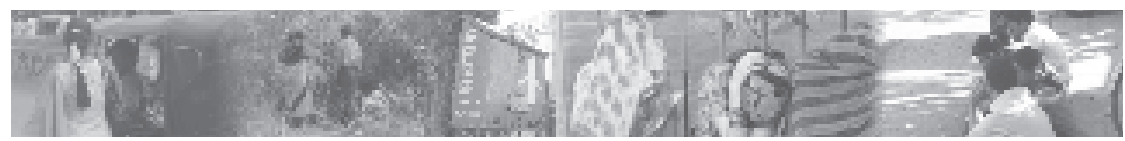

Figure 2 : Mobility of female sex workers by district

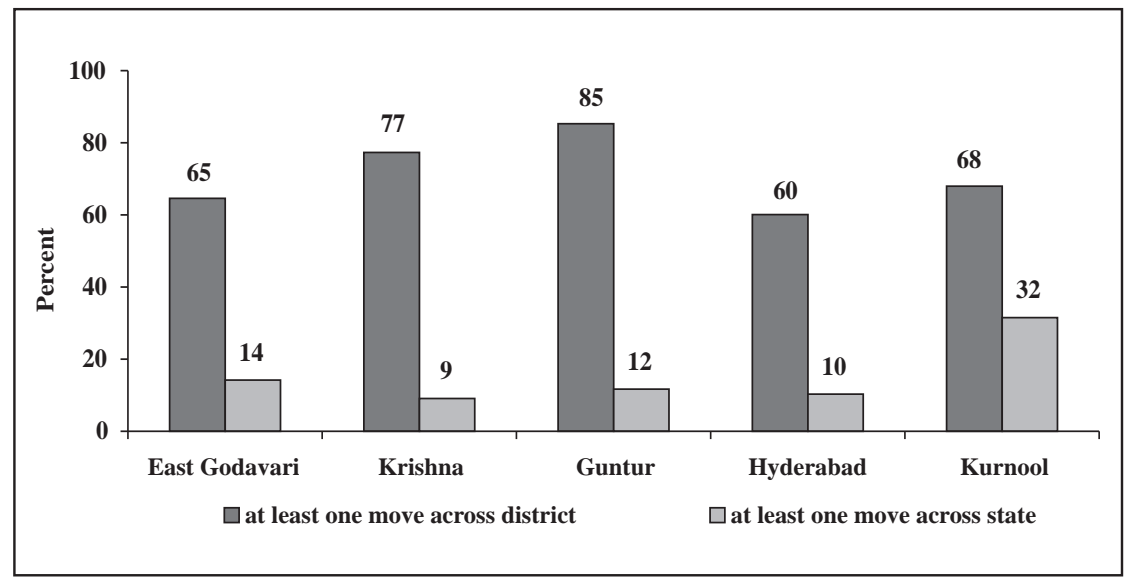

There was inter-district variation in the extent of mobility among female sex workers. Least mobility was noted among sex workers currently in Hyderabad (60 percent) compared to those in Guntur (85 percent). The lower level of mobility in Hyderabad is perhaps expected as Hyderabad being the largest city in the state, provides more opportunities and outlets for sex work than other smaller towns and cities in Andhra Pradesh. Therefore most female sex workers in Hyderabad may not move outside the city as frequently as those from other places for the purpose of sex work.

Mobility by age indicates that sex workers across all age groups are mobile. However, mobility is highest among sex workers aged 25 years or more (see Table 1). 


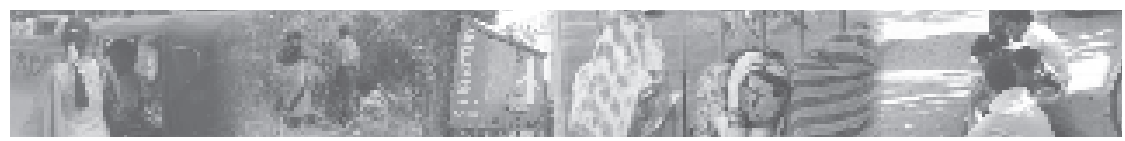

Figure 3 : Percent of mobile female sex workers by age group

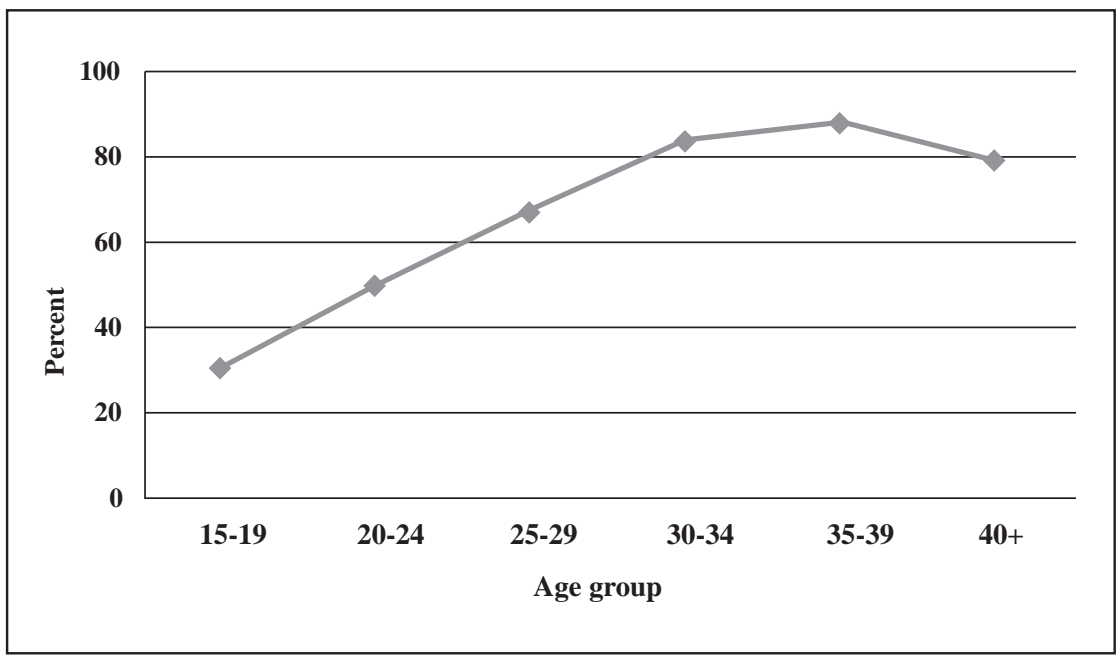

Overall, there is no link between mobility of sex workers and the location where they were contacted. More than two-thirds of sex workers, irrespective of their places of contact, have moved to two or more places in the last two years (see Table 2).

In-depth interviews with sex workers also indicated that sex workers are mobile irrespective of the typologies (based on places where they were contacted). This is contrary to our hypothesis that brothel-based sex workers are likely to be more mobile than street or highway-based sex workers, with home-based sex workers being the least mobile. It was also assumed that, as sex workers in brothel areas may be younger and operating under a structured contract system, they would be most likely to be sent to brothels in other towns for sex work. However, the study findings indicate no difference in mobility patterns of the sex workers, which may be due the following reasons: 1) typologies are artificial and there is a lot of overlap in the places where sex workers operate; 2 ) some of this mobility is part of a contractual system under 


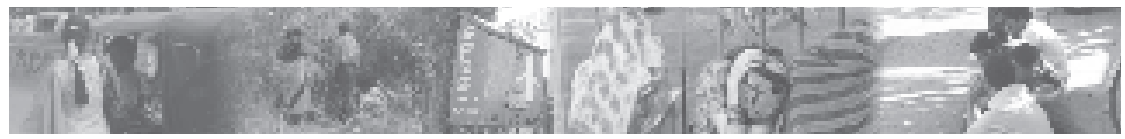

which sex workers move to different places in order to maximize the clientele; 3 ) some of the women who work as agricultural and construction labourers and as dancers in dance troupes and engage in sex work to earn an additional income do not fit into any of the typologies that were described. Some of the quotes to describe these issues are:

"I usually get my clients from petrol bunks, bus stand, theatre, river area, and cattle market. I regularly go to the cattle market on Wednesdays to solicit customers. Most of the people come there from nearby villages and there are more chances of getting customers." (28 years of age, divorced, home based, Kurnool)

"I do daily wage labour work at construction sites. I start at home in the morning at 8:00 a.m. and I come back at 6:00 p.m. If we want work and more money we participate in sex with the mistri (contractor). We also have sex with other workers at the site." (26 years of age, married, typology not clear, Hyderabad)

Some of the sex workers may have a more structured system facilitating their move such as brothel-based sex workers who work through their brothelmadams. Home-based and street-based sex workers mentioned that they have their own 'contacts' such as brothel-madams and colleagues/co-workers who help them get 'contracts' in other towns.

"I work as a daily wage labour and also do sex work. I got a contact from a broker a year after I started doing this sex work. With his help, I have been to lot of places for contract sex work. In the last four years, I have been to Goa about 7 times. I stay there for a month to two months. I went to Mangalagiri, for a one month contract. There were nearly 10-15 brothel houses there and some do sex work in their houses itself. I only go during the summer when my children have school vacations because I have to take care of my children during their school period." (27 years of age, widowed, typology not clear, Hyderabad)

"I have gone to different places. I go and stay in lodges in these places and work for one to two weeks. I recently went to Vizag, and there I stayed for two weeks. I used to go with my friends who used to work with me. They knew everything, and they were superiors to me. I have been to the places like Uppada, Rajahmundry, Tuni, Kakinada, Kathipudi, and Annavaram. Out of all these locations, I go regularly to Kakinada." (26 years of age, single, street based, East Godavari) 


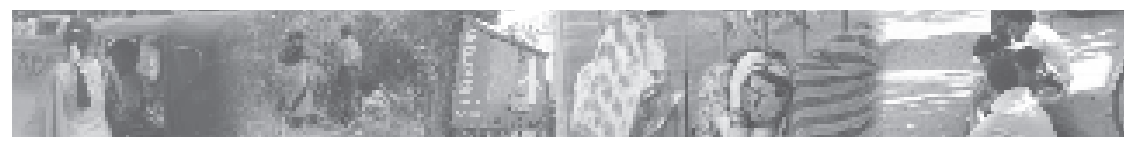

The traditional sex workers, who say they belong to a community known as 'Kalavanthula', mention that they do sex work in their homes and do not go out of their homes or towns on any contract. At the same time they also gave details about the places they have travelled to for sex work.

"Sex workers from our community do not go out for sex work. I have gone out only with three people. So far I have been to Vizag, Vijaywada, and Amalapuram. In Vijayawada, my client, a businessman, took me to his own home for a sex. One of my clients called me for his birthday to Amalapuram. I also have gone to a client's house at Vizag." (27 years of age, single, home based, East Godavari)

In the districts of Krishna and Guntur, female sex workers who were contacted at brothel sites, homes, and highways are reported to be more mobile. Sex workers aged 25 years and over are more mobile across all the districts.

It is also evident that the volume of mobility is higher among those aged 25 years and over, irrespective of their place of contact (see Figure 4).

\section{Figure 4 : Volume of mobility by age and place of contact}

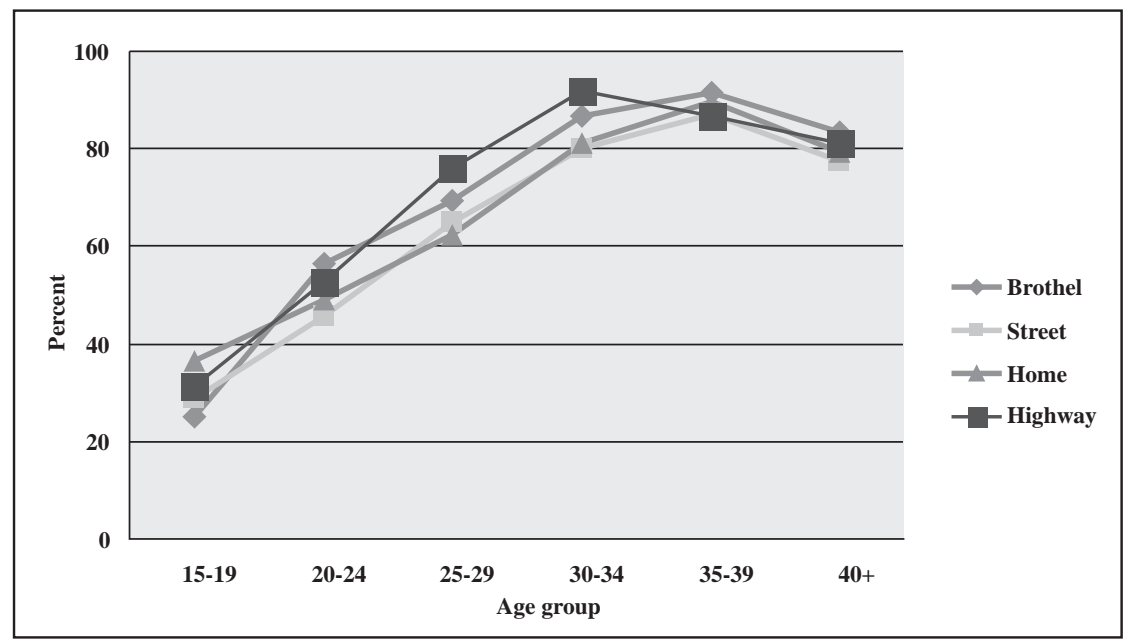

Source : Screening questionnaire 


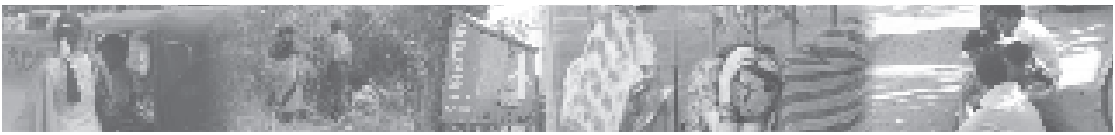

\subsection{Patterns of mobility}

Responses of mobile female sex workers $(n=1,536)$ who participated in the survey provided data to delineate the patterns of mobility. Data on the current place and previous two places are presented visually in the maps. The thickness of the line represents the volume of sex worker mobility, and arrows indicate the direction of mobility. There are four thickness of line weight, indicating (from heaviest to lightest) that over 40 percent of female sex workers travel between the route; between 30 and 39 percent; between 20 and 29 percent; and between 10 and 19 percent. Below 10 percent is not presented on the map as it does not constitute a major route of mobility. The dotted line indicates interstate movements, and the black line indicates inter-district movements within the state.

\section{Map 2 : Mobility routes of female sex workers currently in Hyderabad urban district}

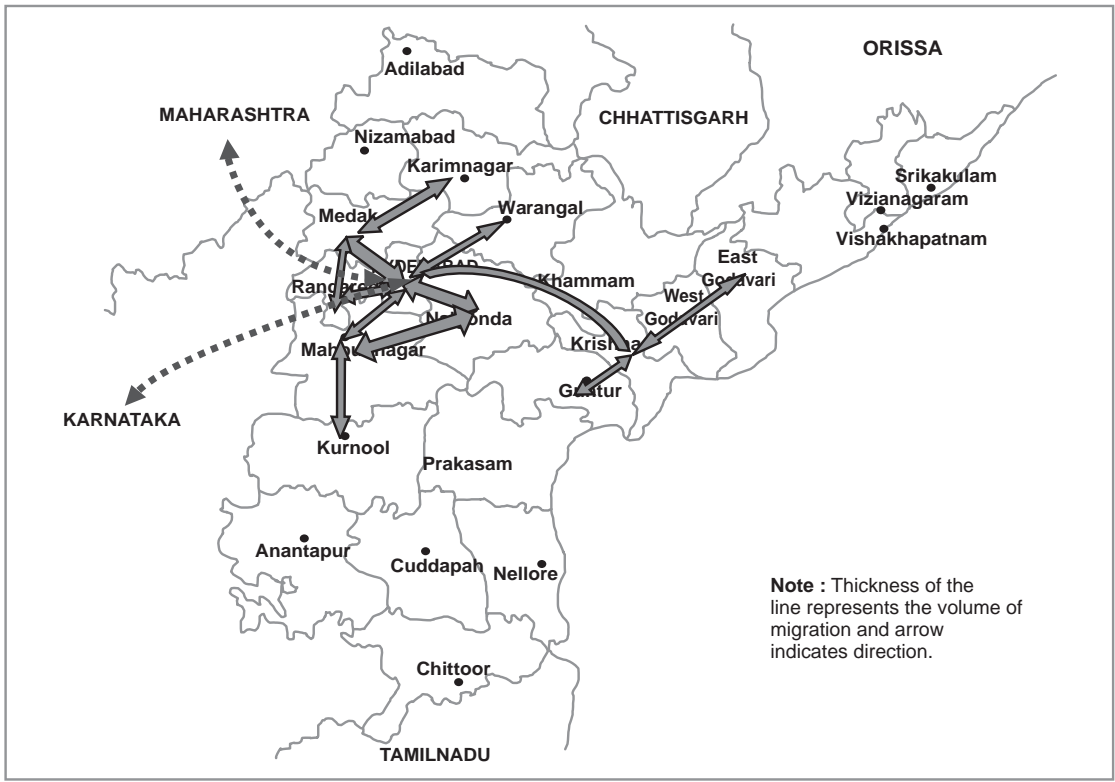

Source : Survey of Mobile FSWs $(\mathrm{n}=117)$ 


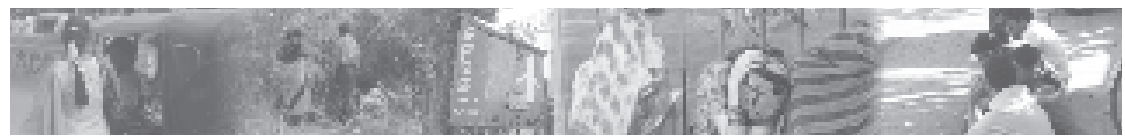

Map 2 indicates that mobile female sex workers who are currently in Hyderabad either came from or had visited other districts within Andhra Pradesh. Large volumes of mobile female sex workers who are currently in Hyderabad visited the districts of Nalgonda, Medak, Karimnagar, Kurnool, and Chittoor. The map also suggests that sex workers move between Hyderabad and coastal districts of Krishna, Guntur, and East Godavari. In addition, the sex workers in Hyderabad visited the states of Maharashtra and Karnataka. The major destination districts for mobile female sex workers in other states are: Mumbai, Pune, and Nashik in Maharashtra; Bellary, Dharwad, and Gulbarga in Karnataka.

\section{Map 3 : Mobility routes of female sex workers currently in Krishna district}

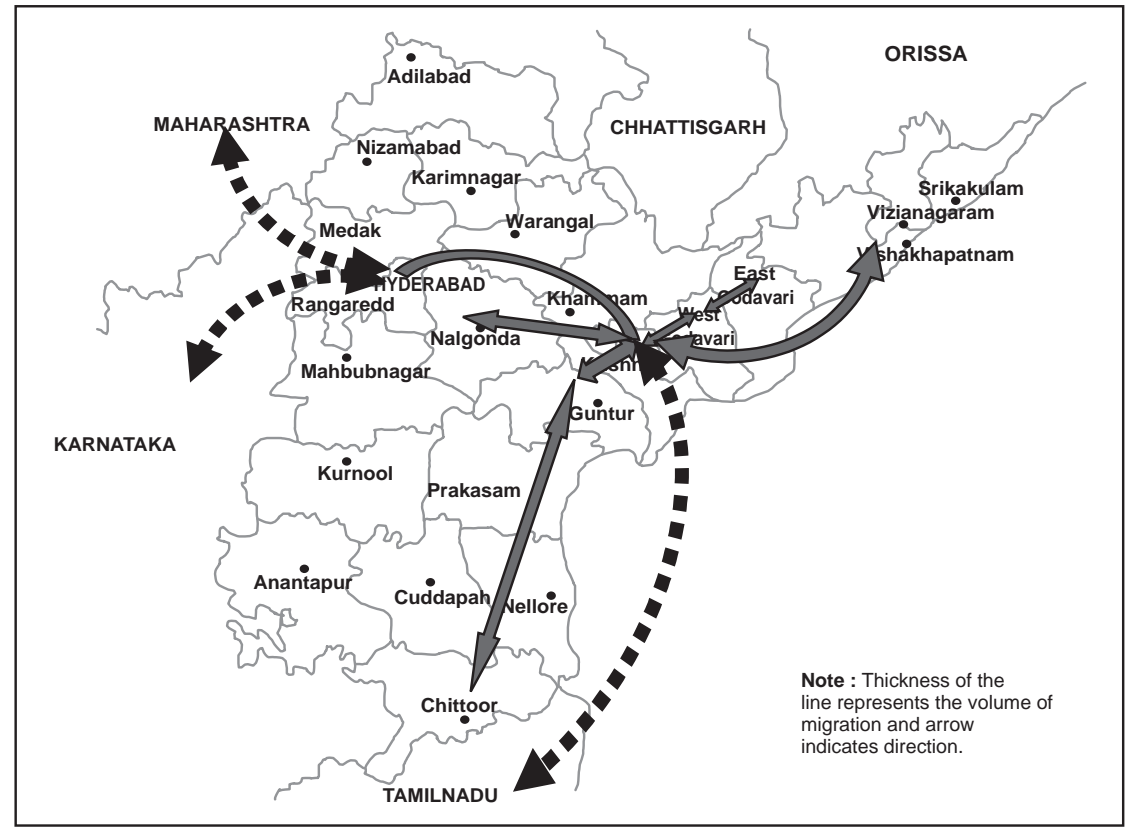

Source : Survey of Mobile FSWs $(n=264)$ 


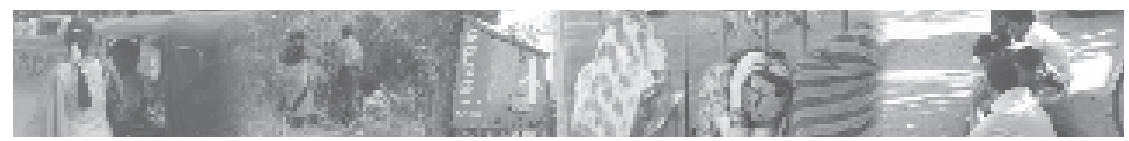

Map 3 shows the pattern of movement for mobile female sex workers currently in Krishna district, and indicates that there is a huge volume of mobility between Krishna and Guntur. The other destinations are: Nalgonda, Chittoor, East Godavari, West Godavari, Visakhapatnam, and Hyderabad. Mobile female sex workers from Krishna district travel to the states of Maharashtra and Karnataka through Hyderabad. There is a strong connectivity of sex workers between Krishna district in Andhra Pradesh and Chennai in Tamil Nadu.

\section{Map 4 : Mobility routes of female sex workers currently in Guntur district}

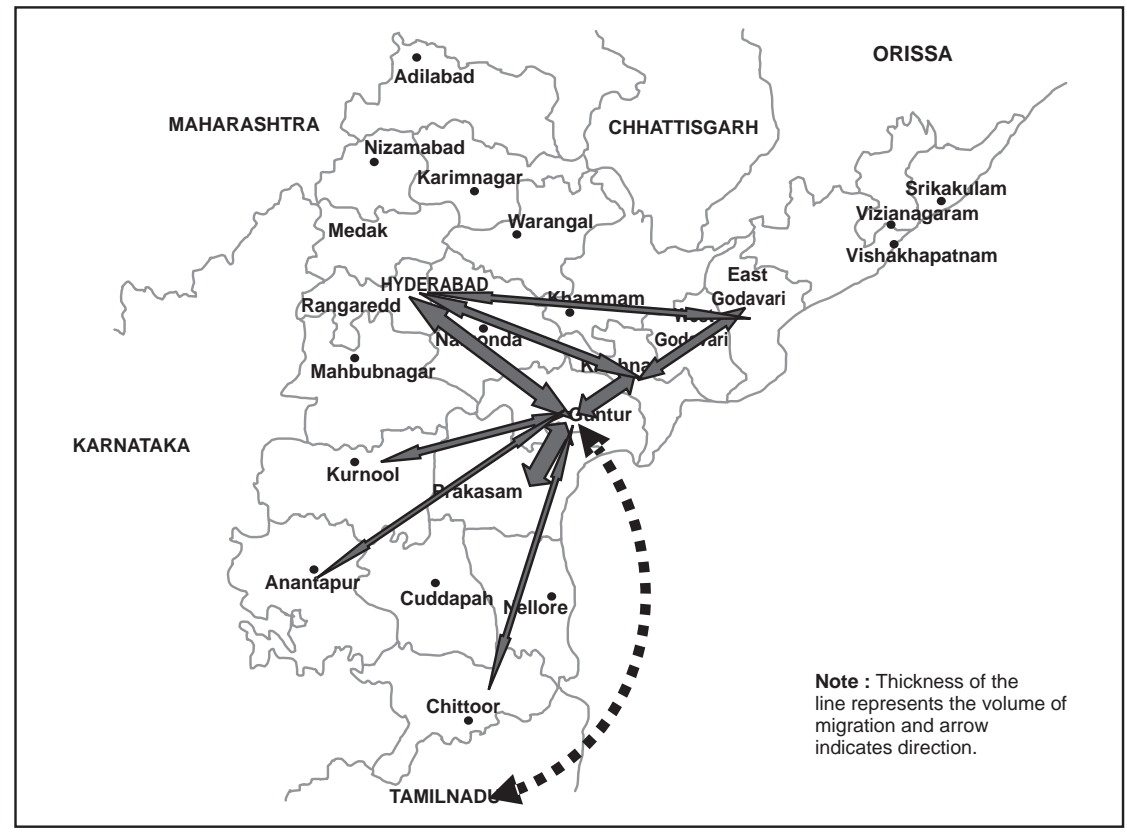

Source: Survey of Mobile FSWs $(n=399)$

Almost 80 percent of mobile female sex workers in Guntur mentioned visits to the districts of Krishna, East Godavari, Prakasam, Nalgonda, Hyderabad, and Chittoor in the last two years. The national highway No. 5 passing through the districts of Prakasam and Guntur facilitates the sex workers' movement between the districts (see Map 4). 


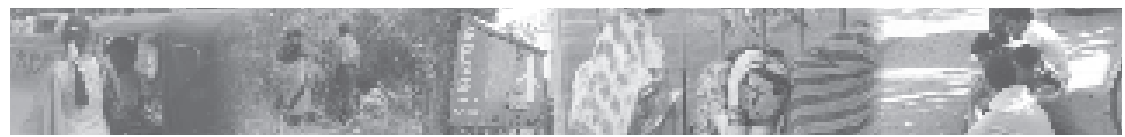

\section{Map 5 : Mobility routes of female sex workers currently in East Godavari district}

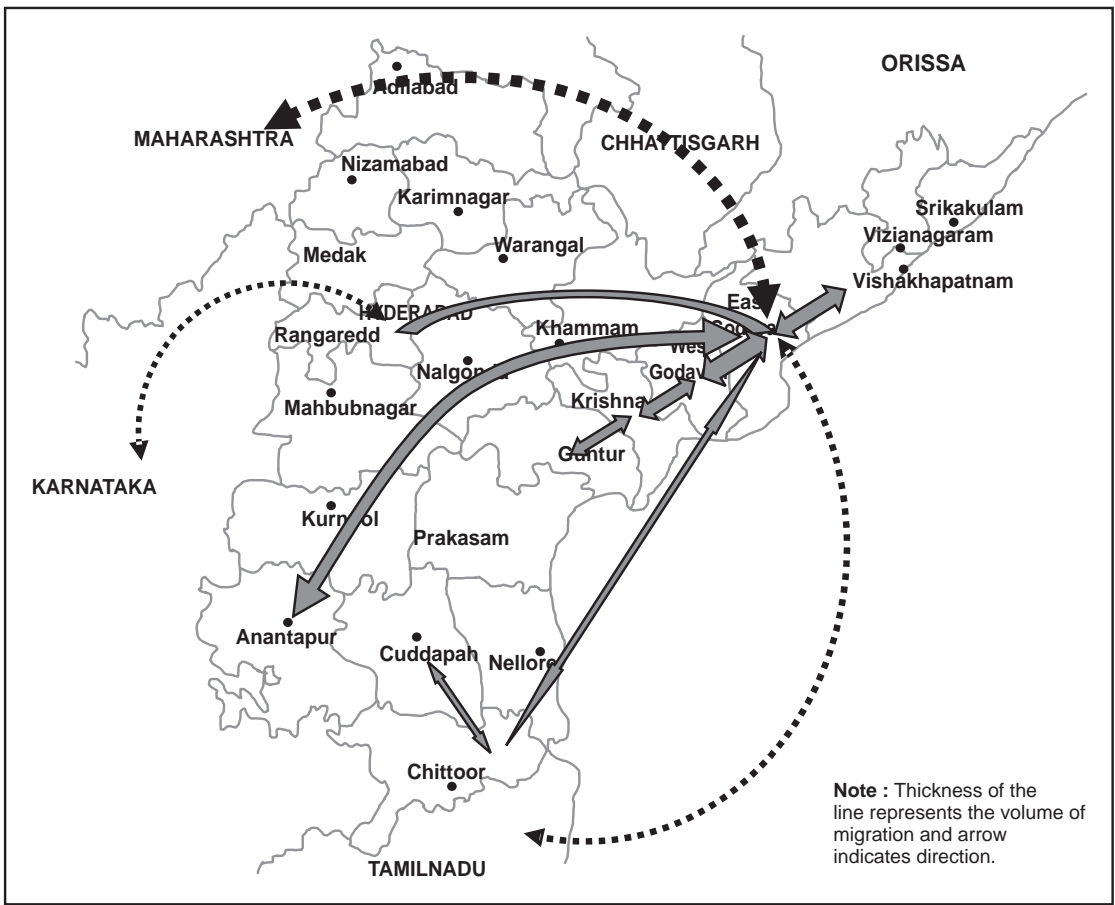

Source : Survey of Mobile FSWs $(n=419)$

Map 5 gives the mobility pattern of female sex workers currently in East Godavari district. The figure suggests a strong connectivity between the coastal districts of Andhra Pradesh and Hyderabad, and between in East Godavari and Ananthapur district. The districts that female sex workers in East Godavari visited are: West Godavari, Visakhapatnam, Krishna, Hyderabad, Ananthapur, and Chittoor. A strong connectivity is noted. Districts in other states that mobile female sex workers visited include Mumbai, Thane in Maharashtra, and Chennai in Tamil Nadu. 


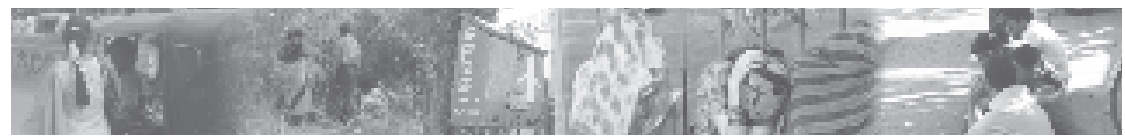

\section{Map 6 : Mobility routes of female sex workers currently in Kurnool district}

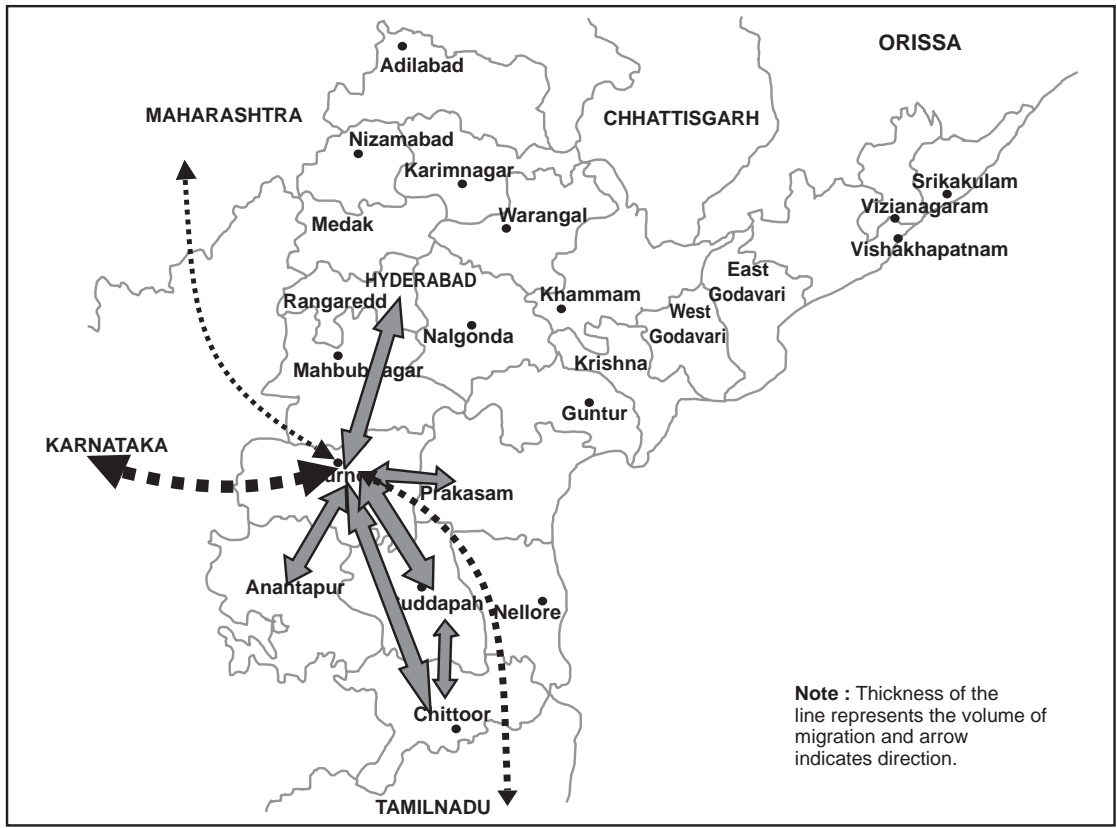

Source : Survey of mobile FSWs $(n=284)$

Map 6 suggests that the mobility pattern of female sex workers in Kurnool district is different from pattern in other study districts. The majority of mobile female sex workers in Kurnool travel to districts in Karnataka. Within Andhra Pradesh, they visited the districts of Ananthapur, Cuddapah, Chittoor, Prakasam, and Hyderabad. A strong connectivity is also evident in the coastal corridor of Andhra Pradesh. One-third of mobile female sex workers visited districts in Karnataka, Maharashtra, and Tamil Nadu in the past two years.

Other features that characterize the mobility patterns of female sex workers relate to religious carnivals (popularly known as 'Jatara') and agricultural seasons whereby single migrant men are drawn in groups to agricultural fields. 


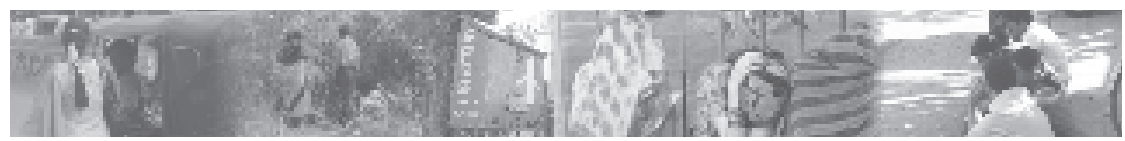

Andhra Pradesh has a number of religious carnivals (Jataras) in which thousands of people assemble for a short period at a specific location. These carnivals/Jataras provide a setting where female sex workers find a ready market for their services. More than one-third of female sex workers from all the districts had visited Jatara locations in the last 12 months, and the majority went to such locations in groups (see Table 3), as doing so provides protection while they are travelling.

The research team has identified 18 types of religious Jatara locations across the state that range from 2 days of Mahankalamma Jatara in Kurnool district to Maridamma Jatara in Peddapuram in East Godavari that lasts for 3 months (see Table 3a).

Figure 5 shows the movement of mobile female sex workers to the town of Nuzvid in Krishna district of Andhra Pradesh during the mango cultivation season in AprilMay. During this season for plucking, marketing, grading, and exporting mangos, numerous male workers move to this town and neighbouring villages. The figure indicates other locations from which mobile female sex workers travel in order to join the men and engage in sex work.

Figure 5 : Seasonal migration of mobile female sex workers in Krishna District

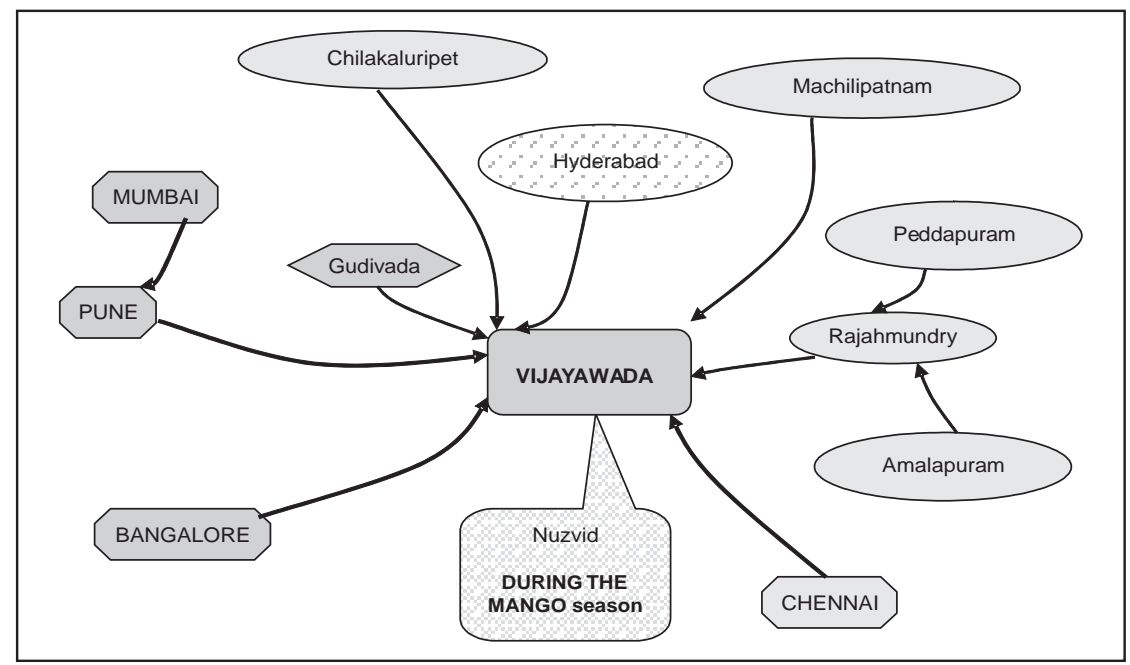




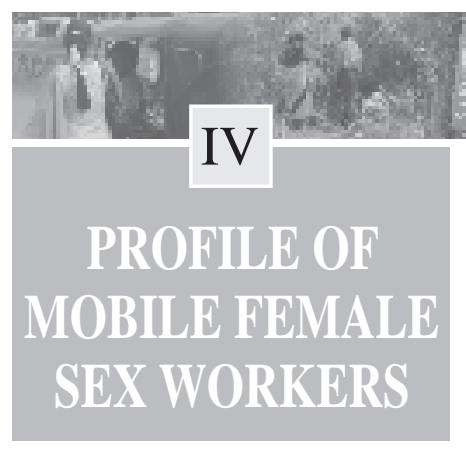

\subsection{Socio-economic and demographic profile}

Eighty percent of female sex workers who were interviewed for the detailed survey in Andhra Pradesh are in the age-group of 25-39 years (see Table 4). Forty five percent of mobile sex workers are illiterate. The mean education among literate mobile female sex workers is six years.

Slightly more than half of the sex workers in Andhra Pradesh were divorced/widowed/separated. This proportion is quite high in East Godavari (71 percent). In most instances, it was the husband who had left the woman as he was involved in an extramarital relationship. Some women had left their husbands mainly because of violence and husband's extramarital relationships. The proportion of unmarried mobile sex workers was low in all the districts (see Figure 6).

\section{Figure 6 : Marital status of mobile female sex workers by district}

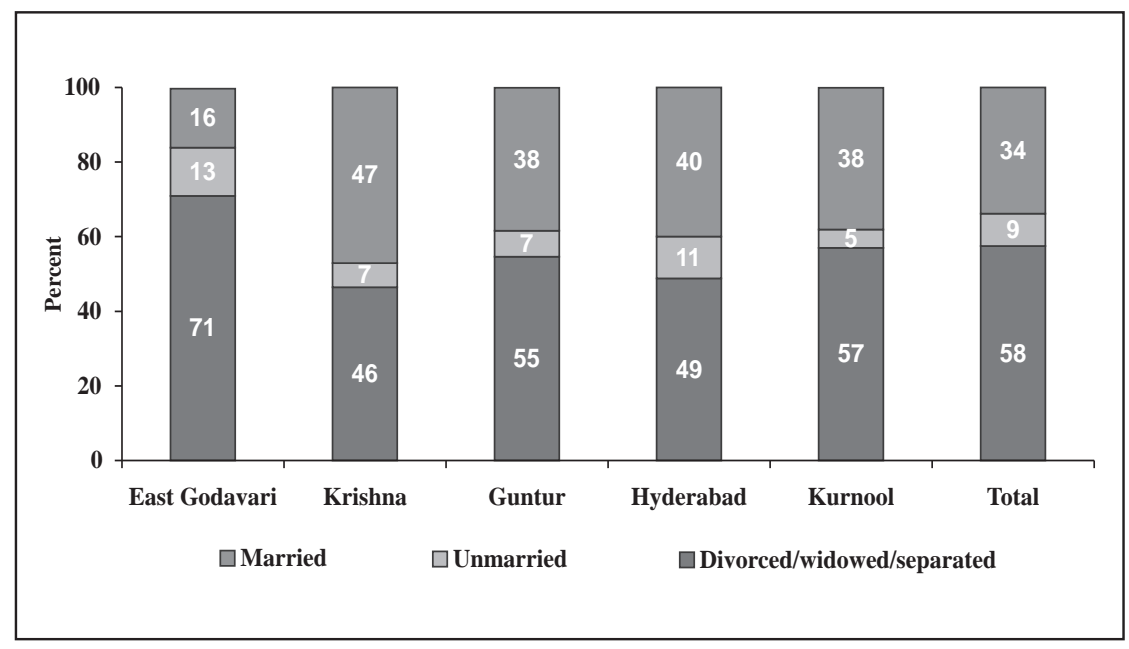




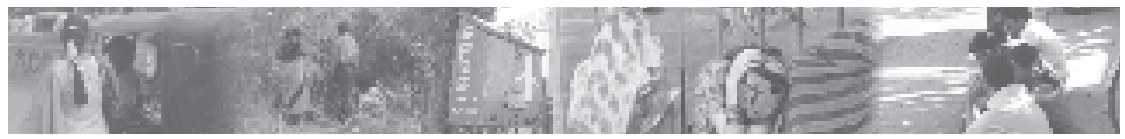

"Once I came to know that my husband had an affair with a girl, my mind started troubling me. I had seen both together in our house only. After she went away I asked him 'if you are interested you marry that girl, I will go away' then he requested me to not make an issue and went out. I thought he will stop going to that girl after that. But he didn't so with my friends' help I came away to Hyderabad."(27 years of age, separated from husband, street based, contacted in cinema theatre, Hyderabad)

"My husband used to beat me regularly. He didn't have a job and used to force me to give him money that I would earn from my work for his drinking. At one time my child was sick and there was no money for food or medicines as my husband had taken all the money for his drinking. So I decided to leave and came away with my child" (Age unknown, separated from husband, street based, East Godavari)

A few sex workers also mentioned that their husbands left them after they learned about their wives' involvement in sex work.

"My husband goes on contract and comes home every 3 months. During his absence one of his friends used to come to our home regularly. One day I was forced to participate in sex with him. My husband came to know about the affair. One day he took me to one house and left me there. Subsequently I came to know that it is a brothel house." (26 years of age, separated from husband, street based, Hyderabad)

"After marriage I used to work as a cook but it did not give us enough money. I started doing sex work as I earned more money. When my husband came to know he did not like it and left me." (35 years of age, separated from husband, home based, Guntur)

In a couple of cases, female sex workers reported that they left their husbands because they were 'unable to do sex work with husband in the house.'

"My husband found out that I was doing sex work and would fight with me. As I was earning more money, I decided to leave him and come away from home because I cannot earn money through sex work with his presence." (35 years of age, separated from husband, home based, Krishna)

\subsection{Sources of income}

Around 40 percents of sex workers earn money through a combination of sex work and sex-related work (Figure 7) such as commissions from referring 


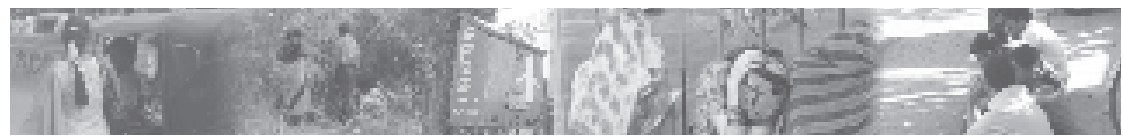

clients and renting rooms for sex. For the rest, in addition to sex work, the women earn income from other occupational sources such as daily wage work, petty business, selling flowers or vegetables, paan shop, contract work, ironing, drama and dance group. This pattern is slightly different in East Godavari district where for more than half of the sex workers, the only source of income is sex work or sex-related work.

Figure 7 : Mobile female sex workers by source of income

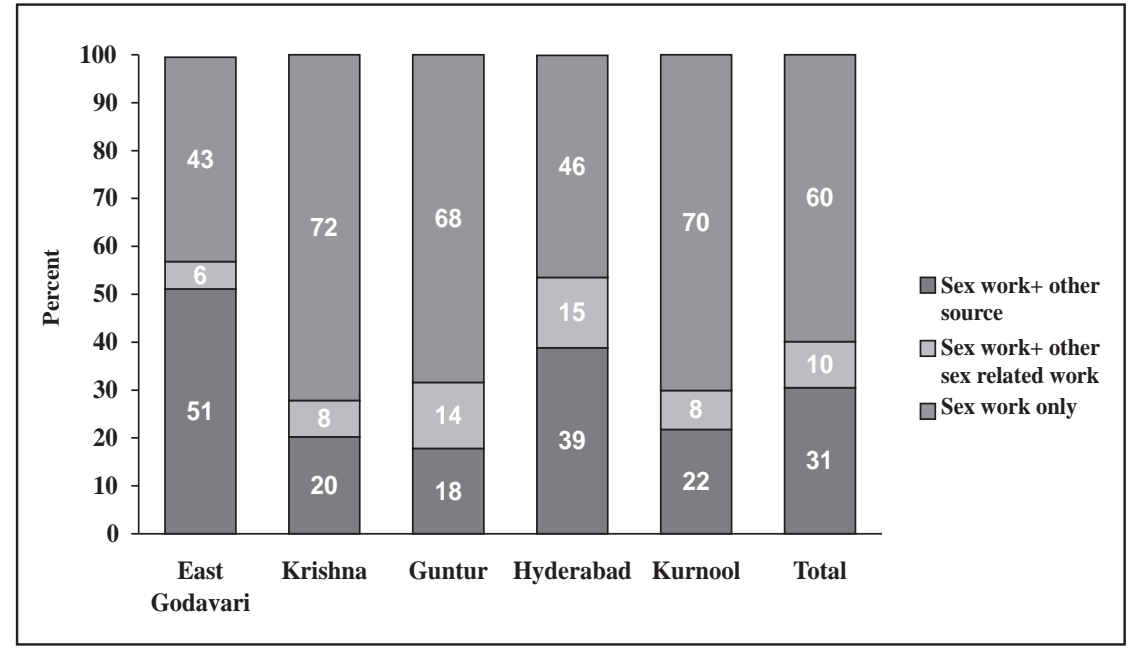

\subsection{Debt}

About 70 percent of mobile female sex workers in Andhra Pradesh owe some money to others, and the amount ranges from 10 rupees to 100,000 rupees. Around 40 percent of sex workers have a debt of 1,000 rupees or more (see Figure 8). 


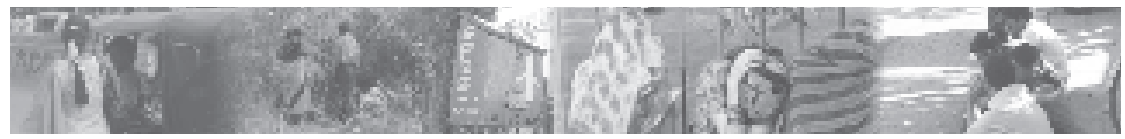

Figure 8 : Percent of mobile female sex workers having debt of various amounts

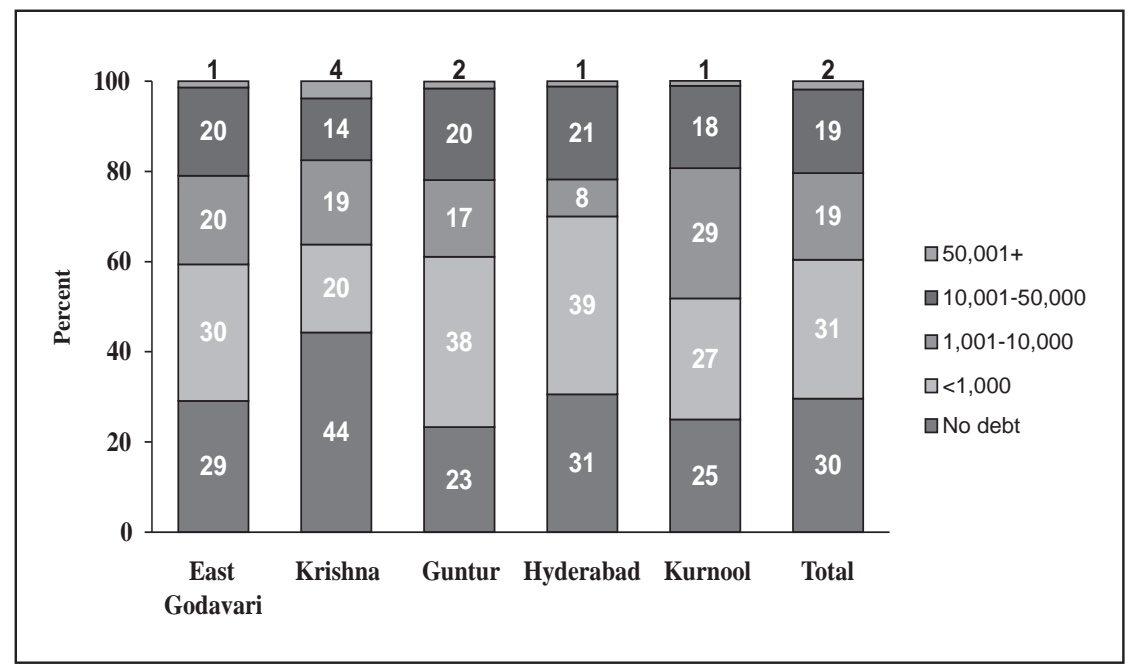

Smaller, comparatively fewer proportions of sex workers who earn money only from sex work have debt than those sex workers who also earn money from other occupations such as agriculture, selling vegetables, flowers, and petty business. There are district-level variations in the amount that they owe to others. Higher proportions of sex workers in Kurnool (75 percent overall; 48 percent have debt more than 1,000 rupees) and East Godavari (71 percent overall; 41 percent have debt more than 1,000 rupees) are in debt compared to sex workers in other districts (see Table 4).

The findings from qualitative research also suggest that most of the female sex workers in Andhra Pradesh were in debt for a variety of reasons, including meeting the expenses for their health or social needs. 


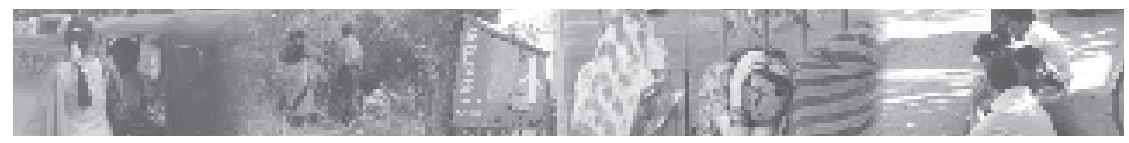

\subsection{Reasons for entry into sex work}

When the female sex workers were asked about their reasons for entering sex work, the majority ( 82 percent) of them mentioned 'economic conditions with or without debt'; 38 percent of mobile female sex workers reported that they entered sex work because they were in debt. This proportion is consistent across all the districts (see Figure 9 and Table 5).

\section{Figure 9 : Reasons for entry into sex work}

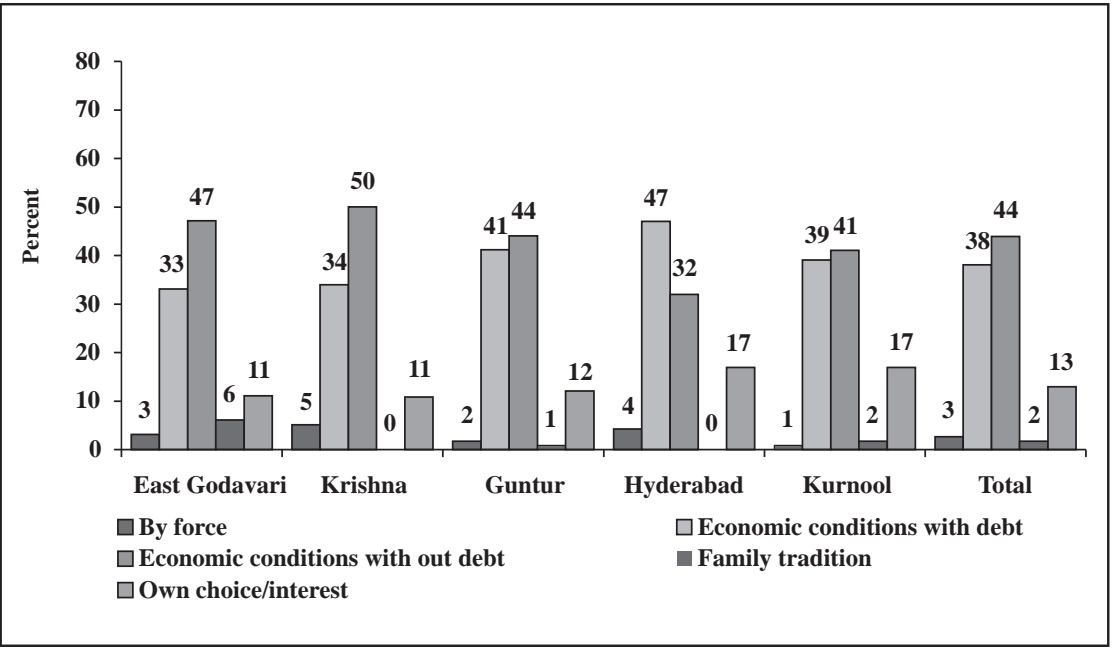

More than one-third of sex workers reported they entered sex work because of 'debt' in their place of origin. Between 11 and 18 percent of females in different districts entered this profession by their own choice, while 1 to 5 percent in different districts were brought into this profession by force (Table 5).

In qualitative interviews, female sex workers confirmed the study findings, with the majority citing poor economic conditions as the reason for entering sex work. This poor economic situation was often the result of being left destitute either by the death of parents or husband, after divorce/separation, or husband's ill-health. 


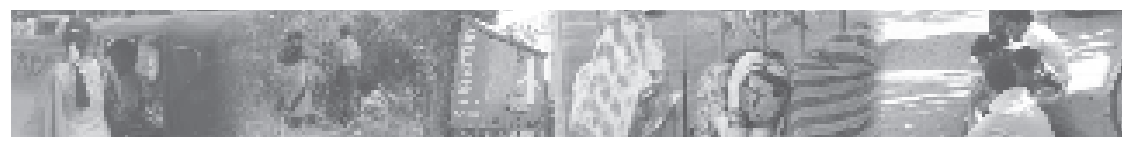

"Economic difficulty is the only reason for entering into this field. My father dies and my mother was ill, so she couldn't work. The wage, which I was earning as a daily labourer, was Rs.50/- per day, which was not sufficient for our daily needs. That is the reason why I came into this field. I have been in this field for the past 8 yrs." (22 years of age, separated from husband, street based, Krishna)

"My husband was drunk all the time. He wouldn't give any money for the family, but he had another woman whom he used to give all his money. In order to feed my two children I had to start this work." (Age not known, separated from husband, street based, contacted at railway station, Guntur)

"The reason for entering this kind of work is economic difficulties. My husband works in a gas company for a meagre salary of Rs.1,000/-. But not only that, my husband has all the bad habits like drinking alcohol, eating gutkha, and etc. Even in sex, he would torture me physically and mentally. Thus I started facing all sorts of difficulties and I was unable to make both ends meet. I have been in this work for the past 6 to 7 years. I came into this field purely due to economic conditions." (31 years of age, currently married, street based, Krishna)

Some of the women also mentioned that they entered sex work in order to pay off family debts or loans taken by family members.

"I, myself, joined this work. My husband had a good job, but then he got into financial problems. We had a chit fund company, but we ended up losing 40 lakhs in the business. We had to sell all our property to clear the loss. We had to sell our property and leave the country for some time to pay back the money. We were able to pay off most of the debt but some still remained. So, I decided to have sex with one of the persons whom we owed money to, because he said that he would clear the remaining debt. When we finally paid off the debt, my husband found out about the arrangement, so he decided to leave me. Later, he divorced me. After that there was no other option for me so I started this work. Now I am earning and living alone, my son is studying in Hyderabad and I send him money monthly." (35 years old, divorced, street based, Krishna)

"My father had lots of debt. He couldn't clear them and took poison and died. My mother was able to clear up some of the debt but not all. She later got TB and died. The money lender then came after me and told me that if I sleep with him for a month, he will clear the remaining debt. No one in my family came forward to help me so I had to go sleep with him. This is how I started sex work six years ago." (25 years of age, unmarried, street based, Hyderabad) 


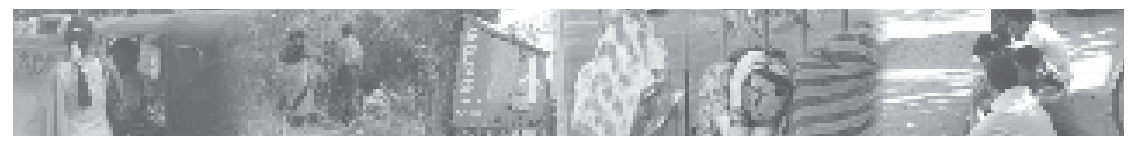

"My mother took loan to celebrate my marriage. After her death I was forced to clear the amount by raising loans from private persons. To clear the loan I decided get into sex work." (28years of age, separated, brothel based, Guntur)

Another sex worker described how she was forced into sex work by her stepfather and uncle.

"... both of them forced me to do this sex work and earn money. When I told them that I won't do it, they put me in a dark room and had sex with me. That torture I could not forget till this day. Then they forcibly pulled me into this profession by selling me for an amount of Rs.3,000/-." (22 years of age, unmarried, street based, Guntur)

In some of the narratives, female sex workers used terms such as 'cheated' or 'forced' or 'lured' when discussing how they entered sex work. But in some cases these terms do not match with the description provided.

"I ran away from home with the man I loved. We lived together for a year without any problems. Later on there were some difficulties because of financial matters and he left me. One of my friends used to work as a sex worker in the area and through her I started sex work. I must have been around 19 years old then." (28 years of age, unmarried, street based, Krishna)

Most of the sex workers who cited their poor financial situation as the reason for starting sex work mentioned that their entry into sex work was facilitated by a person who was aware of their condition, as they had discussed their problem with them.

"My husband died due to kidney failure. I then started working in a garment shop and earned Rs.1,000 per month. The money which I earned was not sufficient for my daughter's education and running of the house. So I asked one regular customer who comes to shop regularly to recommend any jobs where I can earn more. She told me about the sex work and gave me an idea that I can earn 1,000 rupees per day. My position was not good, so I agreed for that. I put my daughter in a hostel and went to Gudivada and stayed in a brothel house. I stayed there for one month and earned 20,000 rupees and continued this work. After that I also stayed in Hyderabad for one year, Rajahmundry for another year, and Peddapuram for 6 months. I have been staying now in Mumbai for about 6 years. I come to Vuyyuru once in every two months and stay for about a month." (35 years of age, widowed, brothel based, Krishna) 


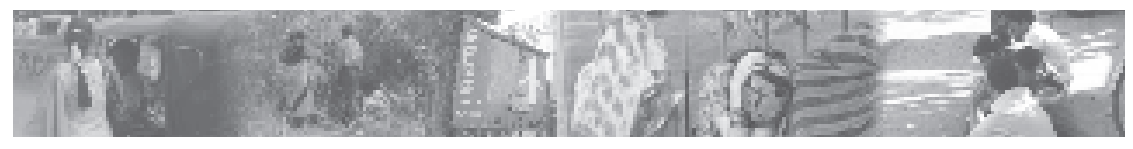

\subsection{Life style characteristics}

As many as four out of five mobile female sex workers used alcohol in the past month prior to the survey. The proportion of female sex workers using alcohol is highest in the district of Hyderabad (95 percent), followed by East Godavari (90 percent) (see Figure 10). Consistently, two-thirds of female sex workers across all the districts used tobacco products (Table 6). Around one percent of female sex workers in Hyderabad and Kurnool used drugs in the past month.

\section{Figure 10 : Percent of mobile female sex workers who reported use of alcohol in the month prior to survey}

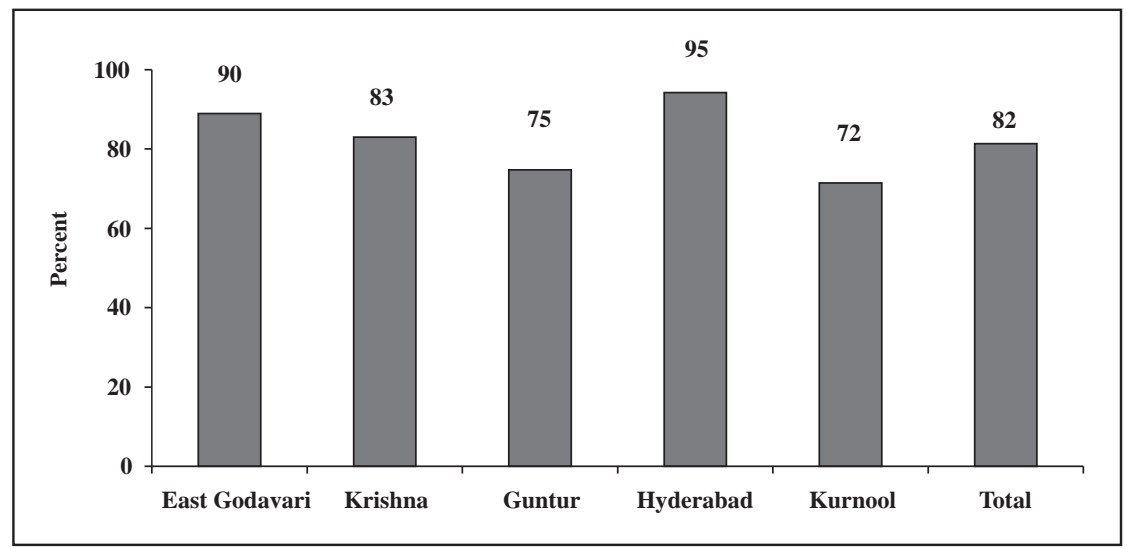

\subsection{Autonomy}

A little more than one-third of mobile female sex workers in Andhra Pradesh have separate bank/post office account, though these percentages varied greatly by district (see Table 7). As many as 60 percent of mobile female sex workers in Hyderabad district have a bank/post office account, compared with 30 percent in East Godavari. It is also evident from the data that the vast majority of sex workers in all study districts are allowed to set aside money for themselves. One-third of mobile female sex workers in Andhra Pradesh had a cell phone. The proportion of female sex workers having a cell phone is highest in Hyderabad (72 percent) (see Figure 11). 


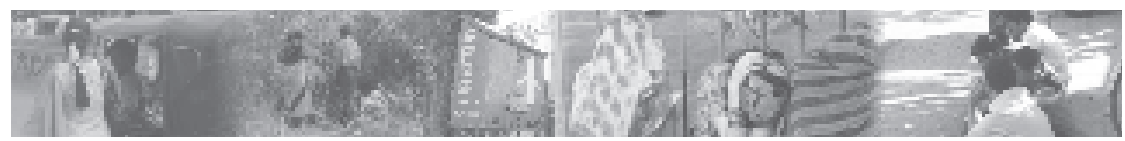

Figure 11 : Percent of mobile female sex workers who reported having a cell phone

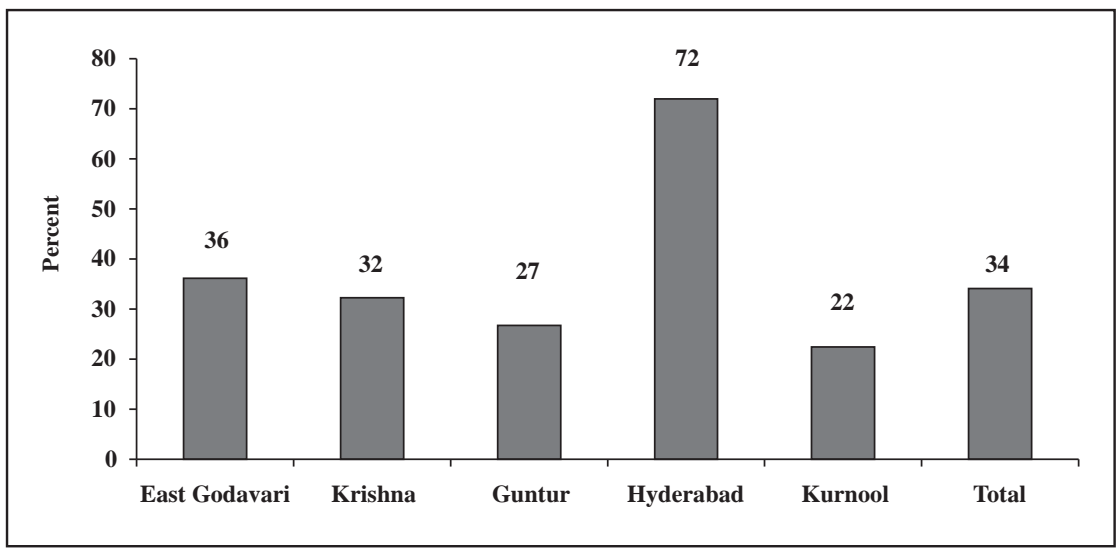

\subsection{Physical violence}

One-third of mobile female sex workers from Andhra Pradesh had experienced physical violence (beating/hitting /thrown out of the house) in the past year.

There were district-level variations in the reporting of physical violence (see

Figure 12). A significantly higher proportion of mobile female sex workers in Hyderabad reported physical violence than in the rest of study districts. A major source of physical violence was from the women's clients. A substantial proportion of mobile female sex workers in East Godavari (31 percent), Krishna (23 percent), and Guntur (22 percent) reported violence by police (see Table 8). 


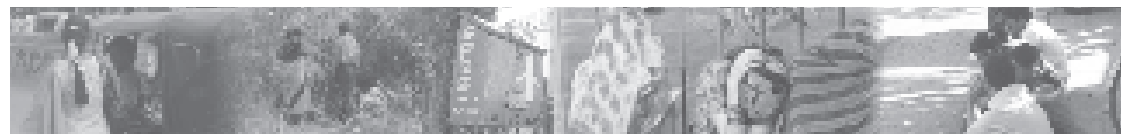

Figure 12 : Percent of mobile female sex workers who experienced physical violence at least once in the past year

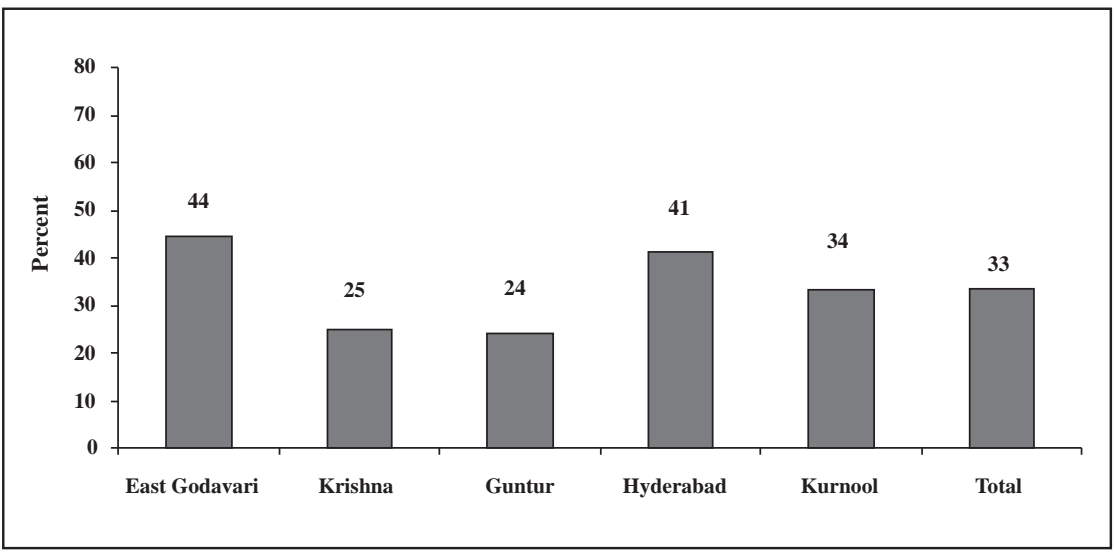

Report from the qualitative survey also describe how female sex workers face physical and emotional violence from different people with whom they are associated in their profession, including police, clients, managers of brothel homes, brokers, and others.

"Once I was caught by police at 12:30 a.m. (after $2^{\text {nd }}$ show cinema); police took me to station and demanded sex. After that another two police people have come and forced to participate in sex." (28 years of age, unmarried, street based, Krishna)

"I have to participate in sex as per his (client) instructions, otherwise he threatens to kill me. One time, after having sex with my client, his friends came over to the place where we just had sex and they demanded to have sex with me. I tried to run away but they stopped me and had sex forcefully." (45 years of age, separated from husband, brothel based, East Godavari)

\subsection{Exposure to mass media and NGOs}

The female sex workers in the survey were asked questions about their exposure to mass media such as newspapers or magazines, radio, television, or cinema. The results indicate that almost every sex worker has watched television or a movie in the past month (see Figure 13 and Table 9). 


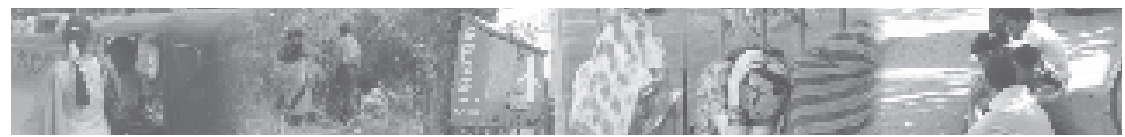

About one-third of mobile female sex workers listened to the radio and onefourth read a newspaper /magazine in the past month. The proportion who listen to the radio ranged between 13 percent in East Godavari and 77 percent in Hyderabad.

\section{Figure 13 : Percent of mobile female sex workers who reported watching television in the past month}

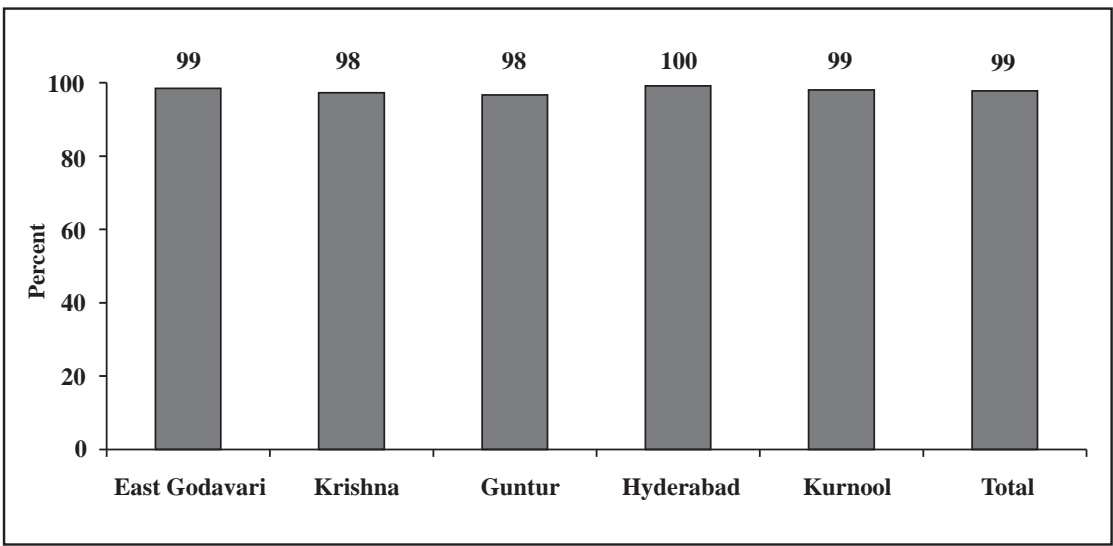

It is evident from the qualitative survey that female sex workers benefit from NGOs and that NGOs are playing a key role in educating them and supplying them with condoms. NGOs and outreach workers are playing an important role in sensitizing them about STI/HIV and even providing referral or treatment to the STI/HIV symptomatic cases.

"Sangha Mitra Service Society regularly supplies condoms to us. Outreach workers of the society teach us about prevention of STIs in campaigns and meetings. With the help of one outreach workers I myself got tested for STI." (26 years of age, widowed, street based, Krishna)

"We get regular feedback on how to prevent HIV and a condom usage." (3I years of age, currently married, street based, Krishna) 


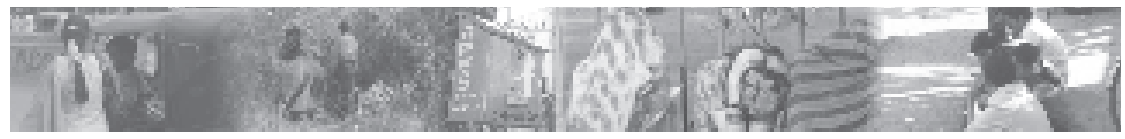

"Initially I was very much reluctant to go to these meetings conducted by Grama siri, but after learning about HIV, I go to meetings regularly. NGO people explained to me about using condom to prevent STI/HIV infection, even though sometimes we are forced to participate in sex without condom." (Age unknown, separated from husband, home based, Guntur)

"I was suffering from 'white discharge' and 'itching on my vagina' for the last 2 years. A peer educator from Kothapeta mahila mandali took me to doctor, gave me medicines for two and half months and advised me to use condoms when having sex without fail. Now I am cured."

(35 years of age, divorced, brothel based, Guntur).

"With the SPES (Sriparameswari service society) NGO worker I go for blood test every 3 months and get treatment from STI clinic. NGO people are very helpful." (35 years of age, separated from husband, street based, Kurnool)

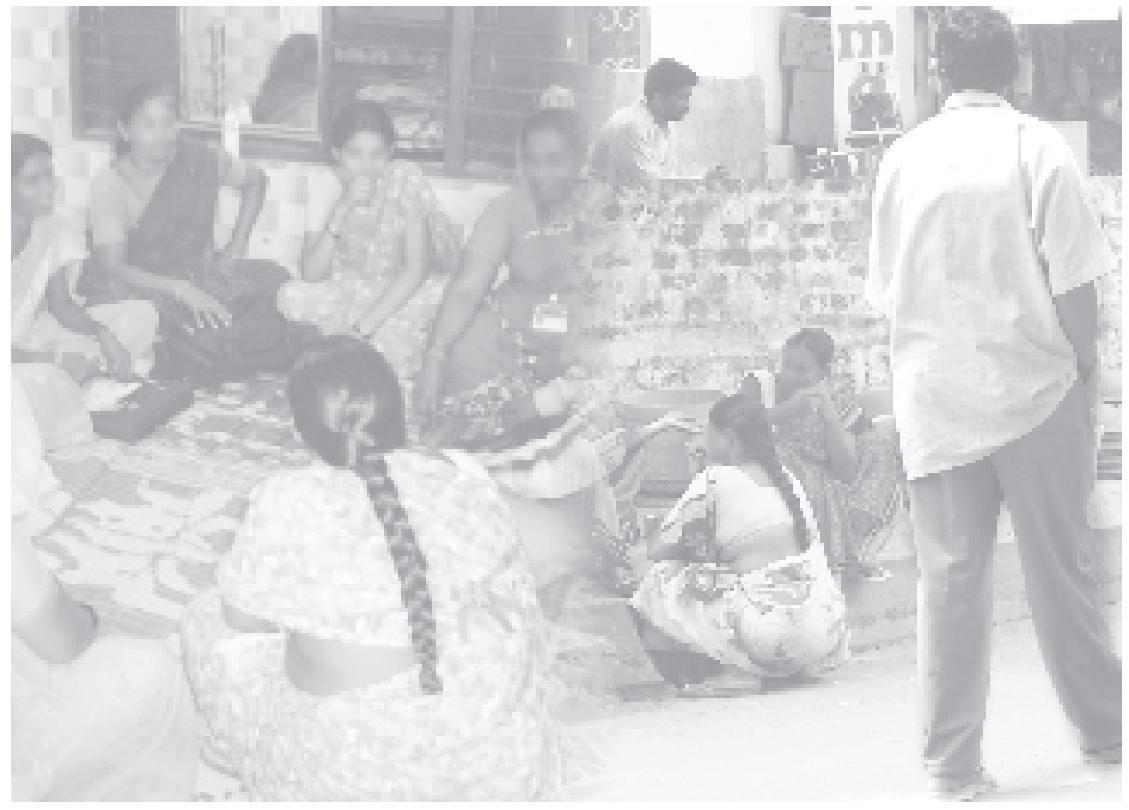




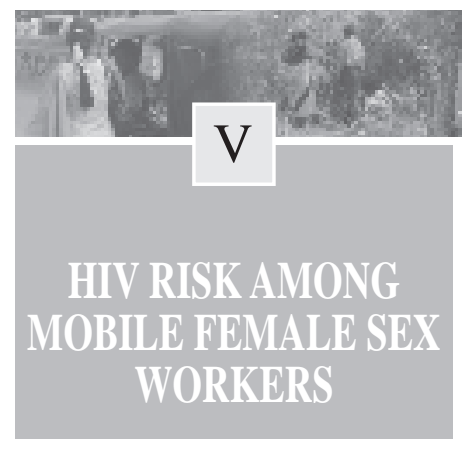

Mobile female sex workers' risk for acquiring HIV infection was measured using the indicators of consistent condom use with: occasional clients, regular clients and nonpaying partner; experience of STI symptoms in the past six months; continuing to have sex while having STI symptoms; sexual violence and condom use during such an incident; and self-perception of risk for HIV. These indicators were cross-tabulated with condom negotiation variables, socio-demographic and economic characteristics, alcohol use, and violence and mobility characteristics. The association between degree of mobility and the indicators of HIV risk are examined in this chapter.

\subsection{Type of partners}

In the survey, mobile female sex workers were asked to specify the number of partners with whom they had sex in the week prior to the survey. Ninety nine percent of the mobile female sex workers interviewed reported having sex with occasional or regular clients, while less than half reported sex with a nonpaying partner in the week prior to the survey (see Figure 14).

Figure 14 : Percent of mobile female sex workers who reported having sex with types of partners in the week prior to the survey

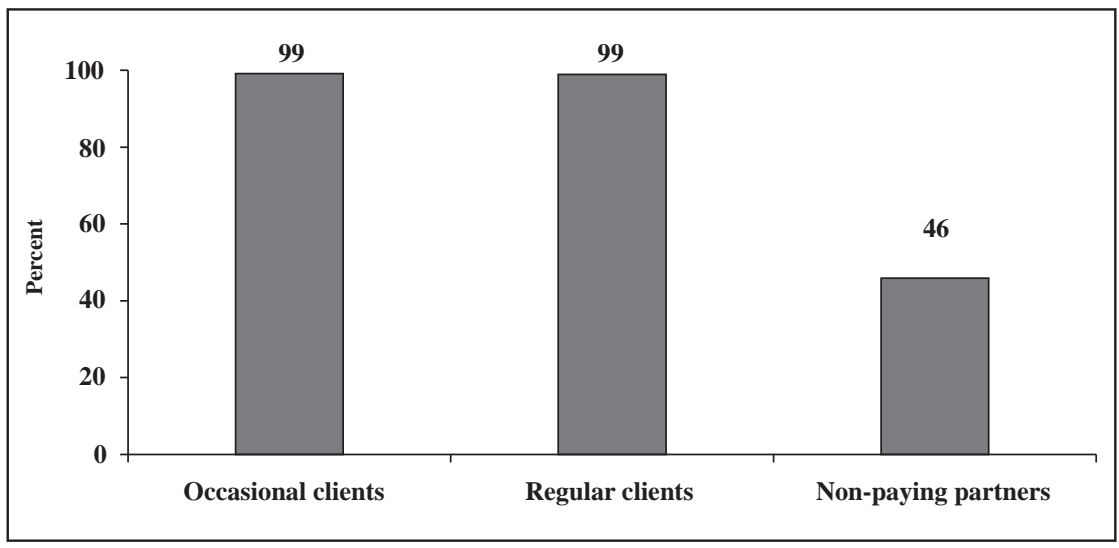




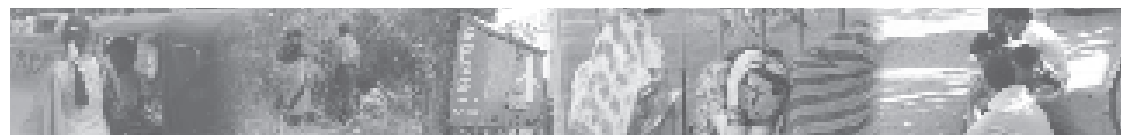

\subsection{Consistent condom use with type of partners}

Mobile female sex workers were asked whether they had used condoms every time that they had sex with different types of clients in the last week. If a sex worker consistently used condoms with all her clients (by type), this is considered consistent condom use. Analyses of consistent condom use by type of client indicate that 84 percent of mobile female sex workers used condoms consistently with occasional clients; the corresponding percentages declined with regular clients (72 percent) and with nonpaying partners (46 percent) (see Figure 15).

Figure 15 : Percent of mobile female sex workers who reported consistent condom use by type of clients

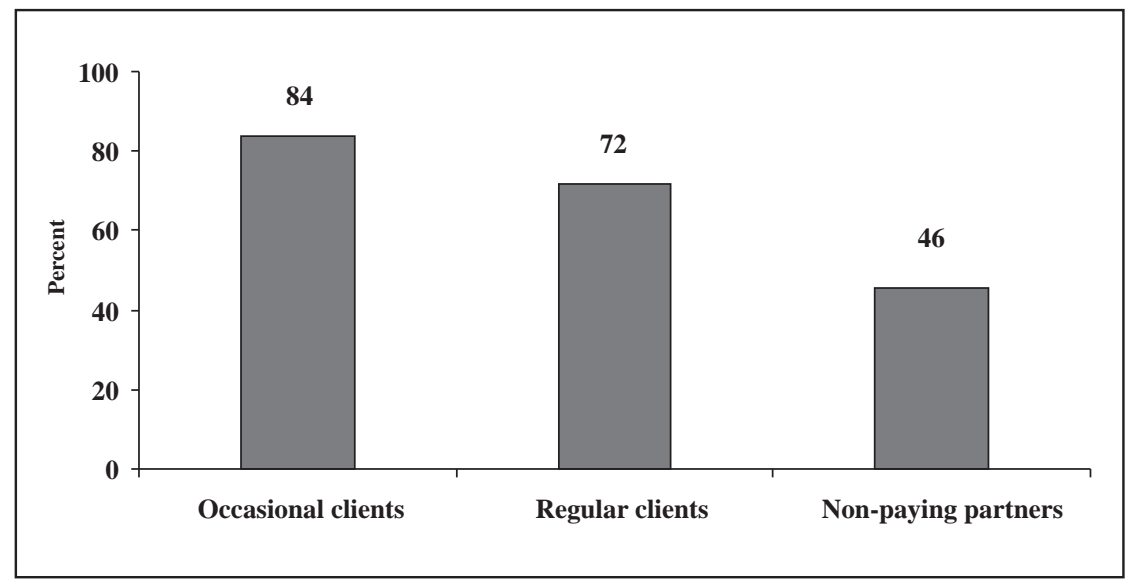

\subsection{Consistent condom use with type of partners by district}

The percentage of mobile female sex workers consistently using condoms with any partners ranged from 52 percent in East Godavari to 72 percent in Krishna and Guntur. 


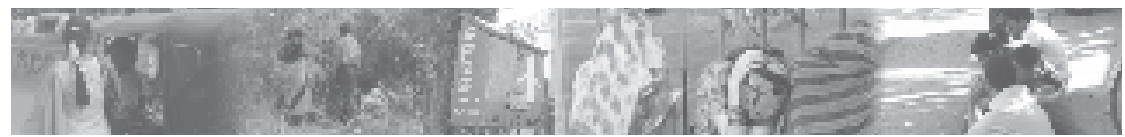

\section{Figure 16 : Percent of mobile female sex workers who reported consistent condom use by type of client/partner by district}

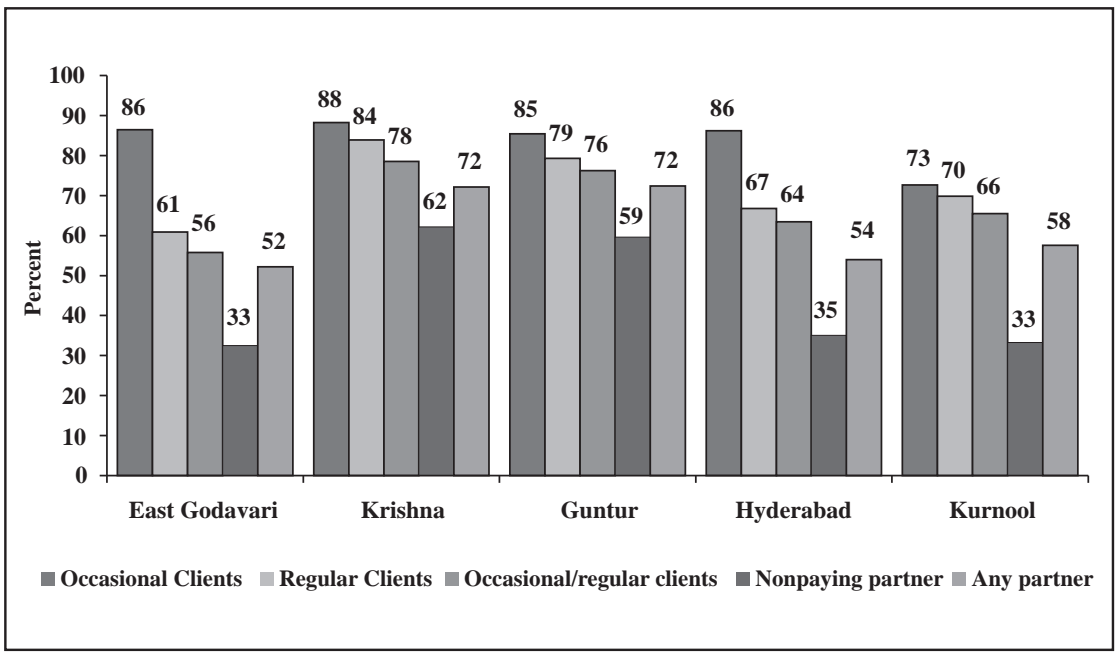

Note: Consistent condom use with any partner was computed taking the weighted average of the clients (occasional and regular clients, nonpaying partner) that she had sex with in the last week.

There are district-level variations in consistent condom use. A higher proportion of sex workers in Krishna and Guntur are using condoms consistently than the sex workers in other study districts. Consistent condom use specifically with regular clients and nonpaying partners is low in the districts of East Godavari and Kurnool (see Table 10).

\section{$5.4 \quad$ Self-reported STI symptoms}

A high proportion of mobile female sex workers (67 percent to 79 percent) reported that they had at least one of the eight STI symptoms at least once in the past six months. More than one-fourth of the mobile female sex workers continued to have sex after reporting STI symptoms (see Figure 17). 


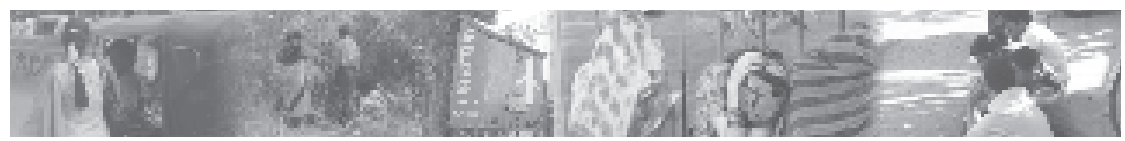

Figure 17 : Percent of mobile female sex workers who reported STI symptoms, and who continued sex while having STIs

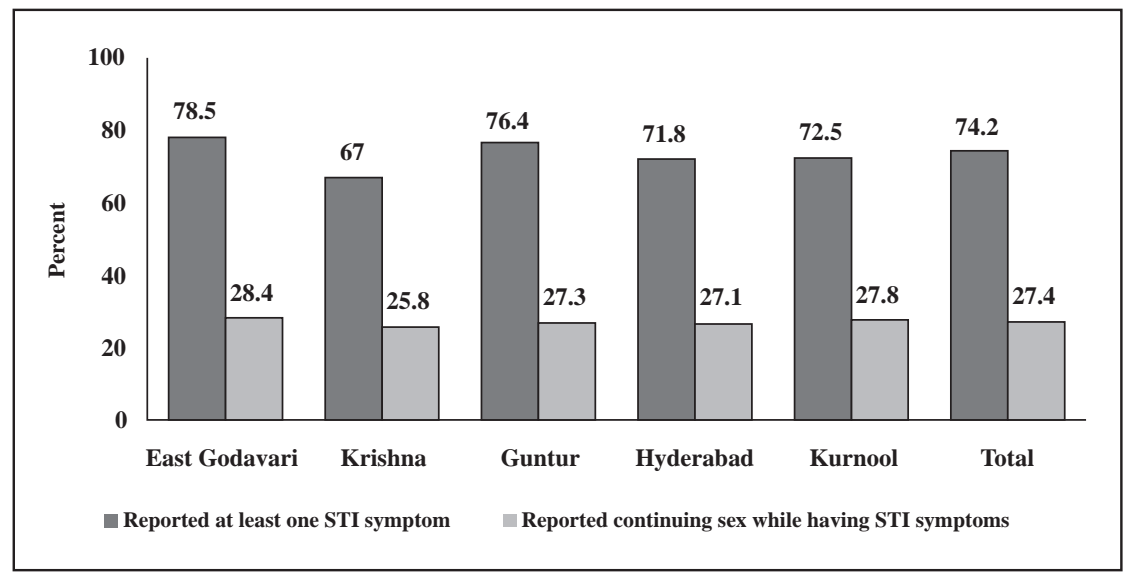

Note: Percentage of sex workers who had at least one of the following symptoms in the last 6 months: excessive vaginal discharge, foul smelling discharge, ulcers /sores in genital area, swelling in groin area, pain during intercourse, itching in genital area, pain in lower abdomen, frequent/sometimes painful urination.

\subsection{Perception of HIV risk}

More than half of the mobile female sex workers reported perceiving either high or moderate risk of getting HIV infection (see Table 10). Almost all of the female sex workers interviewed in the survey reported having been tested for HIV, of whom only one-third went for testing voluntarily.

\subsection{Ability to use condoms and actual condom use}

Condom negotiation is low in most of the study districts of Andhra Pradesh. One-third of the mobile female sex workers reported non-use of condoms due to lack of availability. Among the study districts, the proportion of such respondents ranged from 27 percent in Guntur to 39 percent in Hyderabad. A similar percentage of mobile female sex workers reported non-use of condoms 


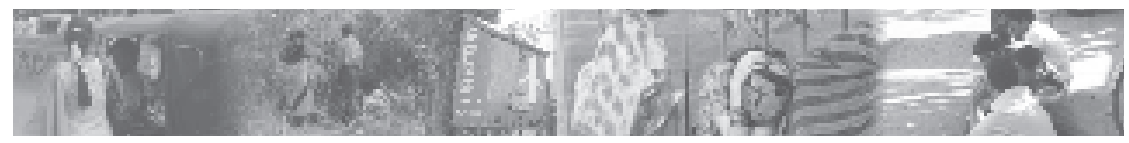

because of clients' refusal. In Kurnool, 44 percent of female sex workers reported such a situation. Only 60 percent of the female sex workers could convince their clients to use a condom if the clients were against it (see Table $11)$.

The qualitative research also indicated that female sex workers, even though they are aware of the importance of using condoms, especially with unknown clients, are still unable to use them for various reasons, including the lack of negotiating power with the client.

"I know my clients well. I don't use condoms with such people. Mostly the upper class males won't like to have sex with condoms. So I take more money from them and have sex without condoms." (38 years of age, widowed, home based, Kurnool)

"The clients are agricultural labourers, employers, drivers, policemen, students, hamalis, village elders, and etc., and they are from 20-50 years. They come from very far places. Most of them are migrant workers and they don't bring condoms. Here condoms are not available. I get condoms from Nandyala whenever I go. When I have them, I ask the clients to use them. But as the clients also refuse them, I am not so particular."(35 years of age, separated from husband, lodge based, Kurnool)

These findings suggest that some mobile female sex workers do not negotiate condom use with clients and some who do negotiate but not enough to result in actual condom use (see Table 12).

In their in-depth interviews, too, sex workers talked about their inability to negotiate safe sex with clients, and even if they try to negotiate, conditions often do not support the use of condoms with specific clients. For instance, a sex worker talked about her inability to negotiate safe sex with inebriated clients when she was working in other towns during her contract work:

"Both in Goa and Hyderabad, if the clients come to me drunk, I cannot say no to them and they won't listen to me properly to use condoms. So I don't use condoms in such instances." (38 years of age, separated from husband, street based, Hyderabad) 


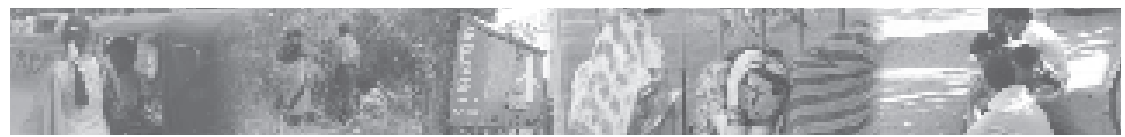

\subsection{Socio-economic insecurity and HIV}

Qualitative data also indicated connections between physical violence and female sex workers' inability to negotiate use of condoms.

"If I refuse sex without condoms, nobody will approach me and I will lose all the clients. So at times I will agree. They will show all kinds of attractions like more money, help outside the lodges, and provision of some house as property, and etc. If I still refuse, they will abuse me beat me." (40 years of age, separated from husband, street based, Kurnool)

"I took Rs. 2000/- from one of my clients to admit my child in school with the condition that I should entertain him without using condoms. I am forced to accept this due to grave necessity. To avoid this type of situation I took the amount for higher interest from my friend and cleared the debt to client." (27 years of age, separated from husband, street based, Kurnool)

Consistent condom use is lower among those mobile female sex workers who also earn income from other occupations (58 percent with any partners) than among those who are completely dependent on sex work (66 percent with any partners). This suggests a need for strengthening programmes for those mobile female sex workers who earn income from additional occupations.

Further, consistent condom use is low among those who are divorced/widowed/separated /deserted (see Figure 18 and Table 13). 


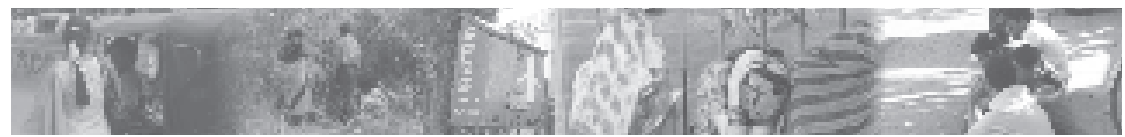

\section{Figure 18 : Percent of mobile female sex workers who reported consistent condom use with different partners by marital status}

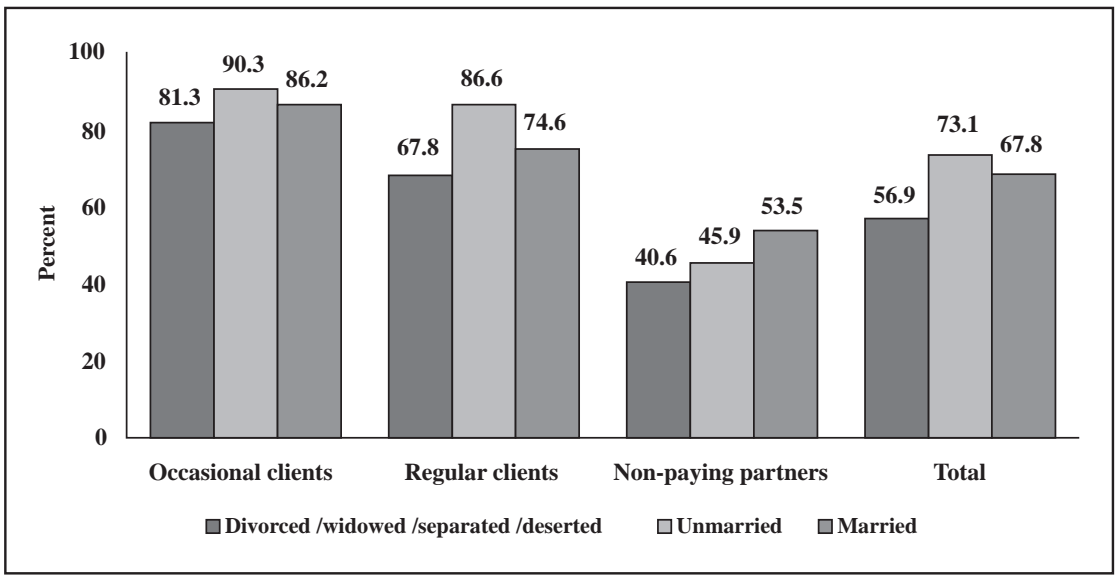

Many sex workers in the in-depth interviews reported forced sex and violence, and most often during such encounters the perpetrators of violence did not use a condom.

"When I was coming from second show I was caught by two rowdies who took me to the nearby dark place. They were already drunk; they also forced me to drink. Then after noticing seriousness of the situation I ran away. On the way police caught me and harassed me for sex. I was forced to have sex." (22 years of age, unmarried, street based, Guntur)

"In these areas some rowdies will also come; usually they are fishermen and others who come in boats. They never give money but ask us to participate in sex. If we refuse, they beat us and abuse us. They also snatch away the money from us. They ask to participate in sex for very long hours till they are satisfied. Sometimes a group of people come and take away our clothes and participate in sex one by one. They lick, bite and participate in sex. They participate in sex without condoms. If we resist they say they do not get satisfied with condom and without condom they feel satisfied. Thus they ask us to participate in sex for whole day." (30 years of age, separated from husband, street/beach based, East Godavari) 


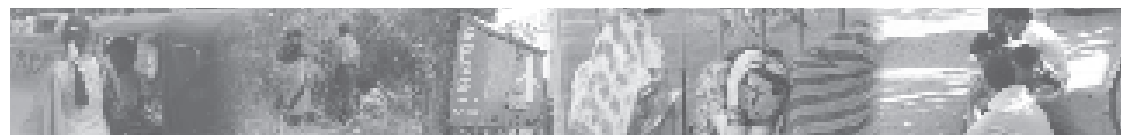

"One time a political person came to me and I refused have sex without a condom. So he promised so many things like: he will pay me more; if anytime police gives me trouble, he will use his influence to help me; he will give good clothes to me; he will use me as his keep; and assured seats in the hostels for my children. When I refused firmly, he beat me then raped me without a condom. But still I did not file a case against him as my profession is bad and I won't get support." (40 years of age, separated from husband, street based, Kurnool)

\subsection{Mobility and HIV risk}

Since this study collected data from all mobile female sex workers who made at least two visits in the last two years, at least one of which was outside the district of residence, the continuum of mobility measuring their degree of mobility was constructed as: those who visited only 2 places, those who visited 3-4 places, and those who visited 5 or more places. The results suggest that 8 percent of the mobile female sex workers visited two places, 52 percent visited 3-4 places, and 40 percent visited 5 or more places in the last two years (see Table 14).

A significantly lower proportion of mobile female sex workers used condoms consistently with clients when they visited/stayed in 5+ places (59 percent) in the last two years as compared to those who visited/stayed in just 2 places (74 percent) in the last two years (see Figure 19). Consistent condom use with occasional clients also declined as the number of places sex workers stays/visits increases. 


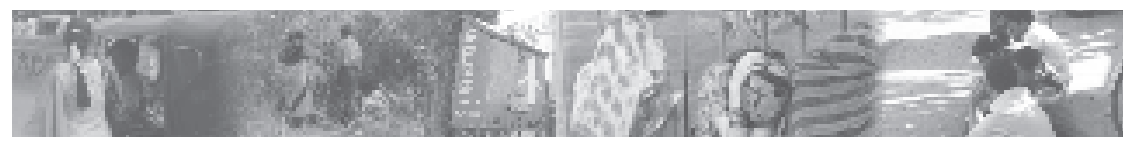

\section{Figure 19 : Percent of mobile female sex workers who reported condom use with different clients by degree of mobility}

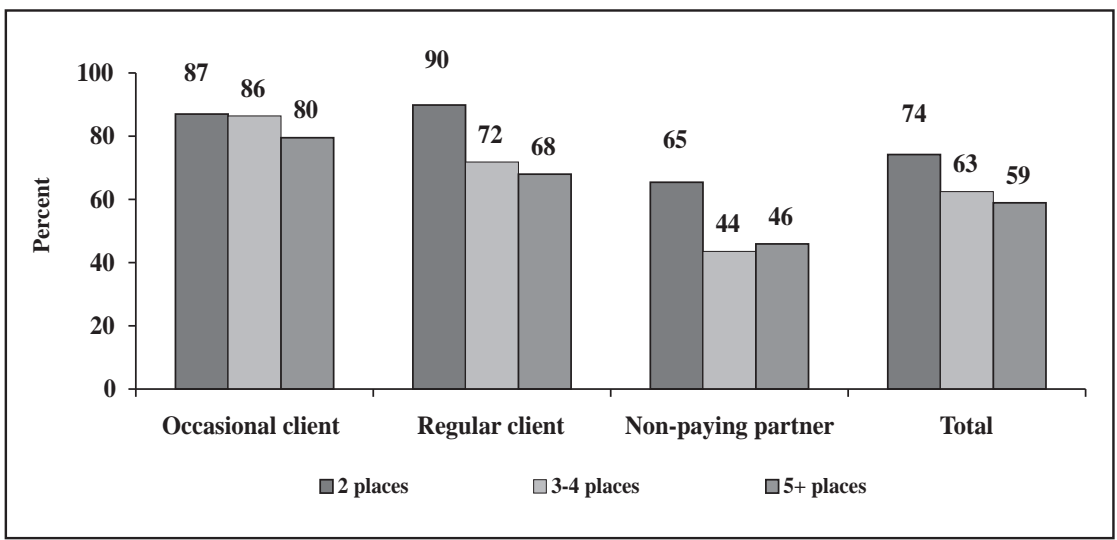

Similarly, consistent condom use is lower among those sex workers who visited Jatara locations alone for sex work. About one-third of the sex workers who visited Jatara locations have not used condoms consistently in those locations. Higher proportions of sex workers from Guntur and Krishna used condoms consistently with their clients in Jatara locations than did sex workers from other study districts.

Further, high proportions of mobile female sex workers who visited/stayed in 5 or more places in the last two years reported STI symptoms and also perceived high risk of acquiring HIV, compared to those who visited/stayed in just 2 places in the last two years (see Table 15). These findings indicate that HIV risk perception and low condom use increase with the increasing degree of mobility among female sex workers.

\footnotetext{
"When I initially entered the sex business, I did not use condoms. I also did not insisted that the clients use condoms. Nobody told me about the necessity of using condoms. One day, NGO staff met with me and explained the need of using condoms, and from that day I started insisting that my clients use condoms. Even so, some clients insist on having sex without using a condom, and they will say they will pay more money. Some occasions I get tempted so have sex without condoms." (25 years of age, unmarried, street based, Krishna)
} 


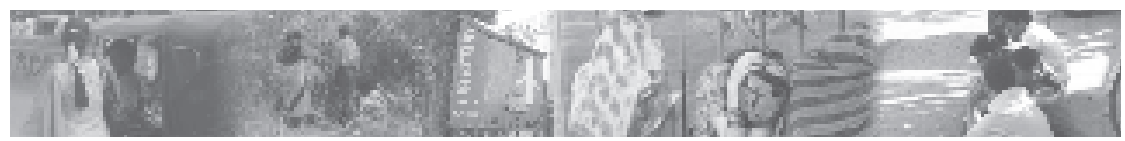

This woman explained her unsafe sex encounter with a client when she was away on contract work. She also discussed other situations when it is not possible to use condoms when she is on contract work away from her brothel and town.

"I went to Nalgonda to a brothel house on contract basis. One day a client insisted on having sex without a condom. Only when I said no, he agreed to have sex using a condom. Then he asked me get naked and started kissing on all parts of my body. After foreplay, he put a condom on his penis. Suddenly he removed condom and performed sex without it. As it was so sudden, I could not do anything. Some clients first approach directly to brothel owner and tell their intention of having sex without using a condom. In such cases also, we can't do anything. Some clients at Hyderabad come with drinks and insist on sex without using a condom. If I do not agree, he would bite my neck, or threaten to kill me. In such cases, even brothel owner can't help me. So I am forced to agree and have sex without a condom." (25 years of age, unmarried, street based, Krishna)

"While I am in Narsaraopet, I always insist on using a condom. But, when I go to brothel houses at Guntur and Vijayawada on contract basis, brothel owners insist to participate in sex with clients without using condoms." (30 years of age, separated from husband, brothel based, Guntur)

"Sometimes, I participate in sex without condoms, particularly in places where condoms are not available (during train rides). It is actually difficult to convince drunken clients to use condoms. This mostly happens to me while I am travelling to Chennai and Mumbai." (21 years of age, unmarried, street based, Krishna)

"I went to Dubai on contract basis and they treated me like a doll. I am forced to have sex with two or three drunken clients and they insisted on having sex in different angles. They have not used condoms. They behaved like animals." (30 years of age, currently married, home based, Krishna)

In summary, the results suggests that female sex workers' risk for acquiring HIV as measured by inconsistent condom use, having STI symptoms, and high self-perception of HIV risk increases with their increase degree of mobility, irrespective of their place of contact with clients (see Table 16). 
IMPLICANIONS HOR HIV PREVENIION PROGRAMILS ACCORDING TO PLACE OR SOLICITAMIONAND SAX
Female sex workers in Andhra Pradesh are highly mobile, and on average each sex worker had visited 2.7 districts in the last two years. To target such highly mobile female sex workers in HIV programmes, a comprehensive understanding of their places of solicitation and sex is needed. This

chapter provides a clearer understanding of the places where the sex workers solicit clients and where they have sex.

\subsection{Places of solicitation and places of sex}

Mobile female sex workers solicit clients at multiple places. The commonly reported places of solicitation are: road side areas, railway stations, bus stands, market areas, hotels or lodges, and own homes. A significant proportion of mobile female sex workers reported that they solicit clients over the phone (23 percent) and from rented rooms (21 percent) (see Figure 20 and Table 17).

Figure 20 : Percent of mobile female sex workers who reported places of solicitation for clients

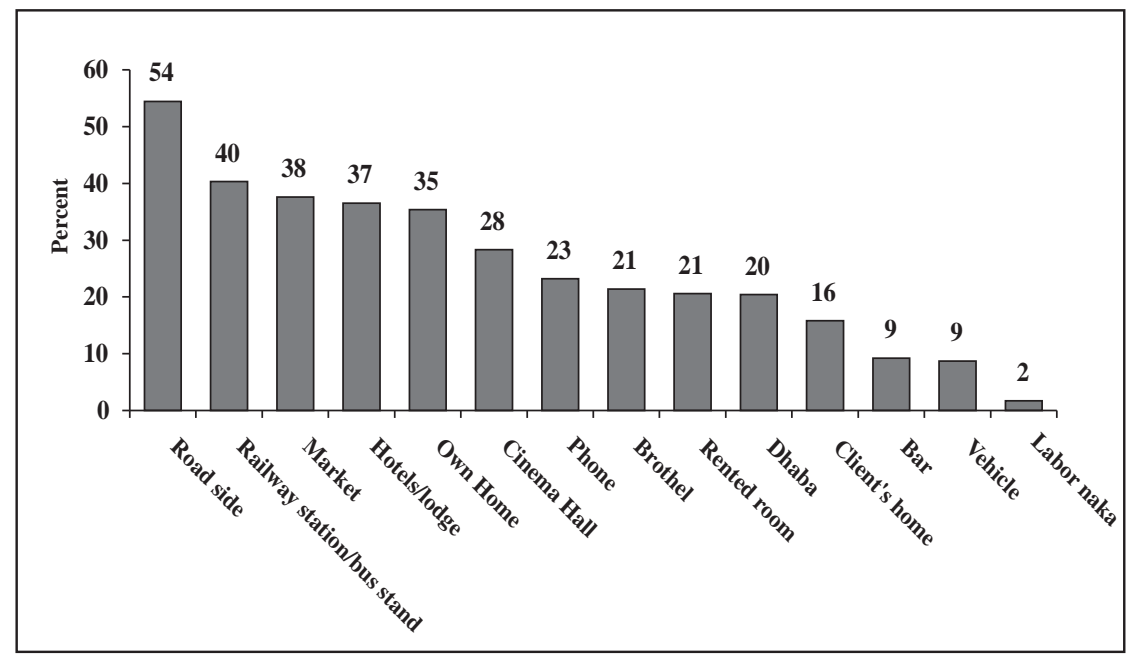




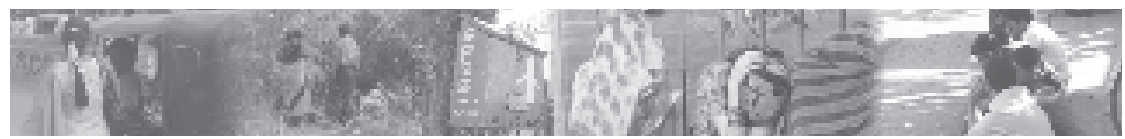

Similarly, mobile female sex workers have sex in multiple places with clients. Rented rooms, hotels, lodges, own home, clients' home, and road side are the common places where sex workers have sex with clients (see Figure 21).

Figure 21 : Percent of mobile female sex workers who reported places where they have sex with clients

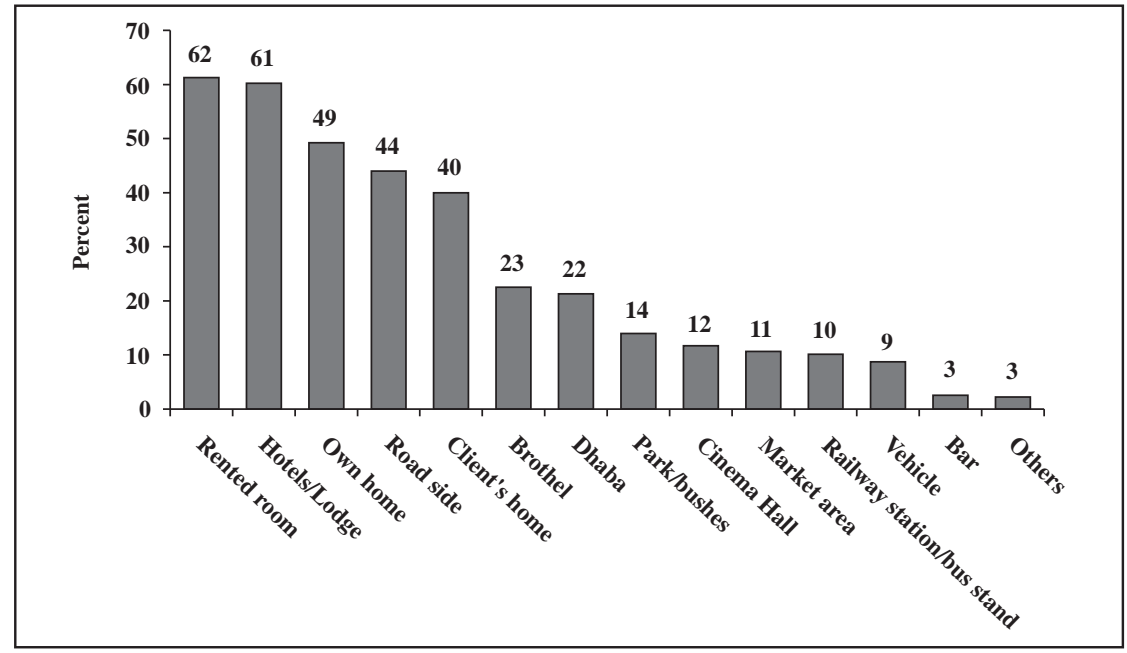

Because mobile female sex workers solicit clients and have sex in various locations, it is difficult to classify them according to any particular location. When we attempted to cross-tabulate the traditional ways of classifying sex workers ('place of contact' as noted by the interviewer) with the place of solicitation/sex (as informed by the sex worker), the results indicate that a significant proportion of female sex workers in Andhra Pradesh irrespective of where they were contacted by the interviewer solicit or have sex with clients in hotels (see Table 18). 


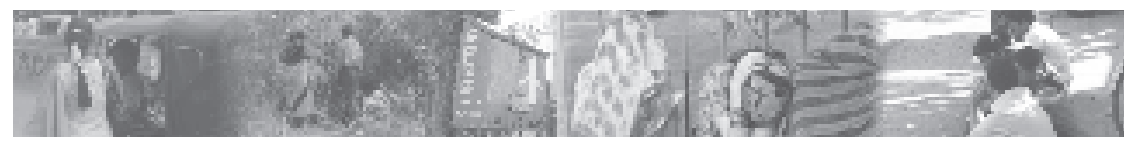

\subsection{Strategies to reach mobile female sex workers in HIV prevention programmes}

Using the top five places as reported by sex workers according to either places of solicitation or sex, an attempt has been made to provide alternative scenarios of optimally targeting female sex workers, so that the maximum number of women could be reached with minimum effort.

Figure 22 : Percent of mobile female sex workers who reported places where they either solicit clients or have sex

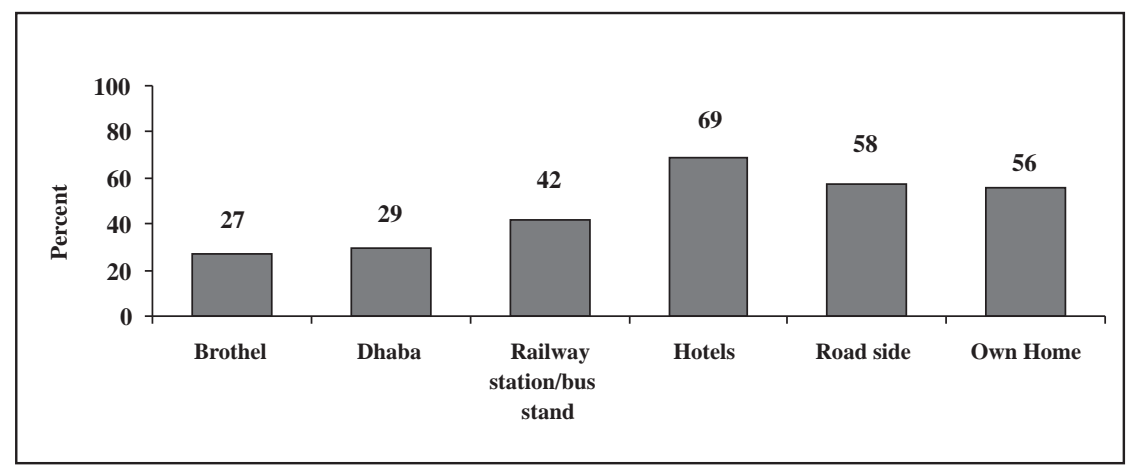

The results suggest that the large majority of mobile female sex workers in Andhra Pradesh either solicit clients or have sex with clients in hotels, road side, own homes, and railway stations/bus stands (see Figure 22). These are therefore the most feasible places for programme intervention. In Andhra Pradesh, brothels, dhaba (restaurants on highways), railway stations, and roadside areas are already the locations being reached by the programme to the greatest extent. 


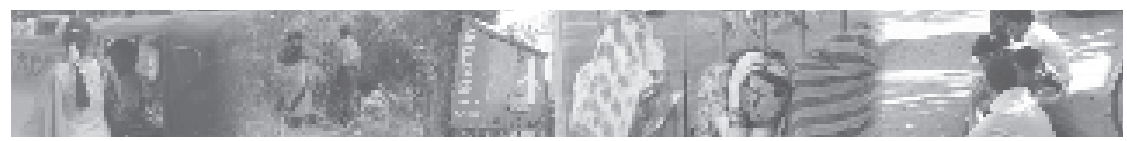

Figure 23 : Anticipated HIV programme coverage of mobile sex workers, if programme is implemented in the following places

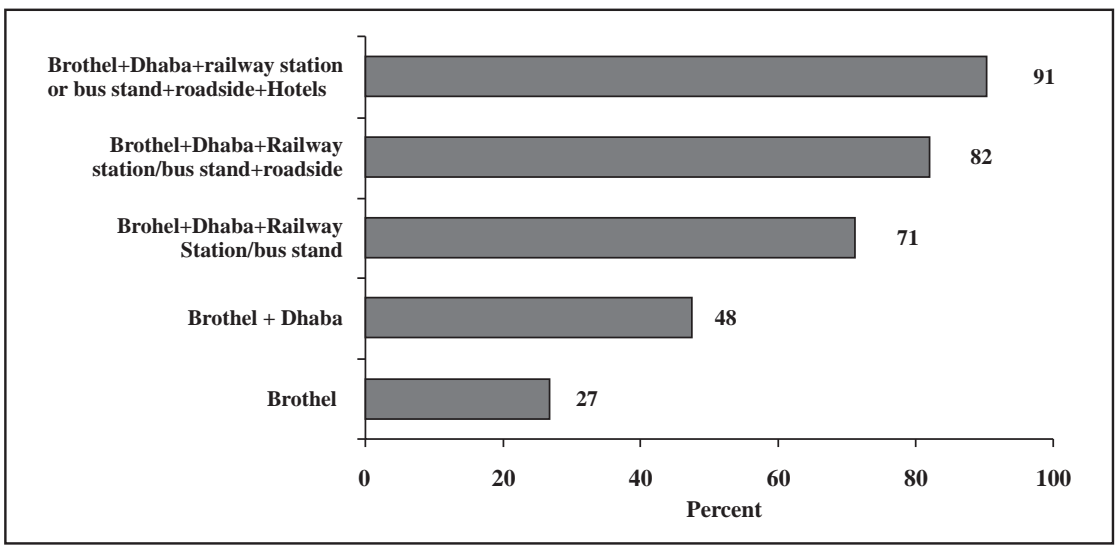

If hotels are included as a place of intervention in sex-worker-targeted programmes (see Figure 23 and Table 19), then it is likely that more than 90 percent of the mobile female sex workers will be covered under the programme. Inclusion of hotels in interventions would significantly increase the coverage of mobile female sex workers in the districts of Hyderabad and East Godavari.

The following reasons provide a rationale for programmes to focus on mobile female sex workers in hotels:

- $\quad$ Seventy percent of sex workers who did not use condoms consistently reported that they either solicit or have sex with clients in hotels. Only 22 percent of sex workers who did not consistently use condoms reported soliciting clients or having sex with clients in brothels. The corresponding percentages for other categories are: roadside (60 percent), railway stations (47 percent), and own home (49 percent).

- Consistent condom use among mobile female sex workers who either solicit or have sex with clients in hotels and/or roadside is far lower than for any other mode of solicitation. 


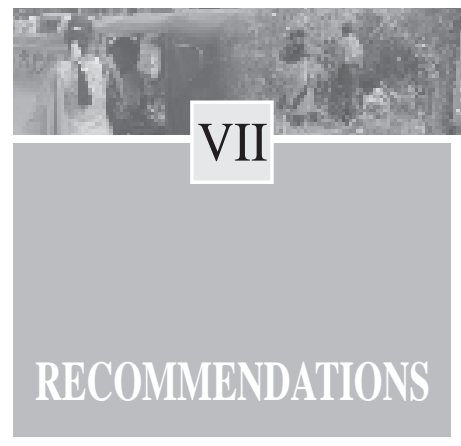

Female sex workers in Andhra Pradesh are highly mobile. On average, mobile female sex workers moved to 4 places for sex work in the last two years. Major routes of mobility appear to be between the study districts, and a strong connectivity is noted in the movement of sex workers between the districts of Krishna, Guntur, East Godavari, West Godavari, and Hyderabad. A large majority of mobile female sex workers go to other states via Krishna and Hyderabad districts. Mobility appears to adversely affect the vulnerability of female sex workers. Highly mobile female sex workers not only reported less consistent condom use but were less likely to use condoms despite having symptoms of STIs. Further, mobile female sex workers who face violence, those in debt, and those widowed/separated/divorced are less likely to use condoms. Mobile female sex workers also reported low consistent condom use with their regular clients. Condoms use is particularly low in sex with nonpaying partners. These results suggest a need for additional programmatic attention in the study districts, especially for those mobile female sex workers who are most disadvantaged socio-demographically and economically. Interventions also must educate mobile female sex workers on the need for condom use with each type of partner, specifically with regular clients and nonpaying partners. Further research is also needed in Andhra on the reasons and modifiable factors associated with low consistent condom use in sex with nonpaying partners.

It is possible that since sex-work-related mobility is undertaken to maximize the trade opportunity, less discretion is applied in the use of condoms. In places where the opportunity for soliciting clients is high and time is short, for example Jatara locations, consistent condom use seems to have declined sharply. About one-third of the sex workers who visited Jatara locations have not used condoms consistently in those locations. There are certain areas and events that create greater vulnerabilities and should form the focus of future interventions, for example, Jatara locations and locations with large numbers of male migrant workers.

Three-fifths of female sex workers also reported additional source(s) of income such as daily wage work, petty business, and so on. It is possible that due to taboos and the illegal nature of sex work, some female sex workers falsely 


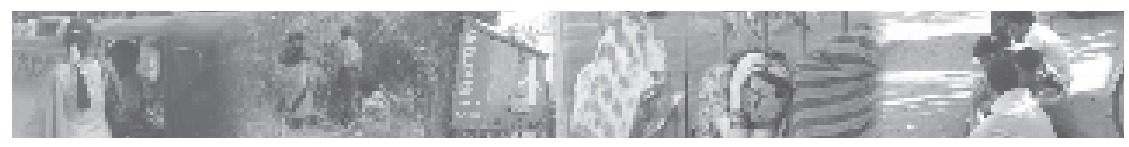

report other types of work. In other cases, it is likely that sex work is a supplement to the income from other sources. There is a need to identify occupations and work areas that may provide cover for the sex work and to approach the women with greater sensitivity so as not to label the occupations yet provide protection for HIV.

Despite enhanced vulnerability and lack of consistent condom use, only a little over half the mobile female sex workers saw themselves at risk of HIV infection. Creative awareness programmes are needed to assess women's own risk perceptions in light of the vulnerabilities that sex workers encounter in their day-to-day lives.

Besides the study districts, mobile female sex workers frequently reported their visits to the districts of Nalgonda, Prakasam, Chittoor, and Ananthapur. The data on mobility indicate a strong connectivity between these four districts and the study districts. Further data on condom use by mobile female sex workers in the districts of Nalgonda, Prakasam, and Chittoor suggest very low consistent condom use along these mobility routes. This suggests a need for programmatic expansion and implementation of social support systems in the districts of Nalgonda, Prakasam, and Chittoor and strategic planning for contacting mobile female sex workers. It also suggests the need for districtspecific interventions for optimum impact, given that HIV vulnerability varies substantially by district.

In Andhra, sex workers are traditionally contacted under the categories of brothel, roadside, highways, dhabas, homes, and railway stations/bus stands. This research study suggests that mobile female sex workers solicit clients in multiple places, and have sex with clients in various places. However, the most common places where mobile female sex workers either solicit their clients or have sex with clients in Andhra Pradesh are: brothels, dhabas, railway stations or bus stands, roadside, and hotels/lodges. These are also the most feasible places for intervention. This finding suggests a need for hotel-based intervention initiatives to cover a significant number of mobile female sex workers, specifically in the districts of Hyderabad, East Godavari, and Chittoor. 


\section{APPENDIX}

Table 1 : Volume of mobility by district, type of place, place of contact, and age group

\begin{tabular}{|c|c|c|c|c|c|c|c|c|c|}
\hline & \multicolumn{3}{|c|}{$\begin{array}{l}\text { FSWs who had moved in the } \\
\text { last } 2 \text { years }\end{array}$} & \multicolumn{3}{|c|}{$\begin{array}{c}\text { FSWs who had moved } \\
\text { across district in the last } 2 \\
\text { years }\end{array}$} & \multirow{2}{*}{$\begin{array}{l}\text { FSWs with 2+ } \\
\text { moves and at } \\
\text { least one } \\
\text { across } \\
\text { district }\end{array}$} & \multirow{2}{*}{$\begin{array}{l}\text { FSWs who } \\
\text { had moved } \\
\text { across the } \\
\text { state }\end{array}$} & \multirow[t]{2}{*}{$\begin{array}{c}\text { Total } \\
\mathbf{N}\end{array}$} \\
\hline & $1+$ & $2+$ & Average & $1+$ & $2+$ & Average & & & \\
\hline District & $\%$ & $\%$ & & $\%$ & $\%$ & & $\%$ & $\%$ & \\
\hline $\begin{array}{l}\text { East } \\
\text { Godavari }\end{array}$ & 95.4 & 90.4 & 3.6 & 64.6 & 50.1 & 2.2 & 63.9 & 14.2 & 649 \\
\hline Krishna & 94.4 & 86.1 & 3.5 & 77.3 & 65.3 & 2.7 & 74.4 & 9.1 & 375 \\
\hline Guntur & 95.6 & 91.7 & 4.8 & 85.3 & 71.8 & 2.9 & 83.5 & 11.7 & 503 \\
\hline Hyderabad & 80.4 & 78.0 & 3.8 & 60.1 & 50.5 & 3.1 & 59.5 & 10.3 & 291 \\
\hline Kurnool & 92.3 & 89.1 & 4.3 & 68.0 & 55.0 & 2.9 & 67.8 & 31.5 & 432 \\
\hline \multicolumn{10}{|l|}{ Type of place } \\
\hline Urban & 92.0 & 88.0 & 4.1 & 71.0 & 59.0 & 2.8 & 69.8 & 17.5 & 1,704 \\
\hline Rural & 95.0 & 89.0 & 3.7 & 73.0 & 58.0 & 2.6 & 71.6 & 9.7 & 546 \\
\hline \multicolumn{10}{|l|}{ Place of contact } \\
\hline Brothel & 94.0 & 89.1 & 4.1 & 74.9 & 60.1 & 2.8 & 73.5 & 24.0 & 366 \\
\hline Hotel/lodge & 88.9 & 88.9 & 4.7 & 88.9 & 88.9 & 3.4 & 83.3 & 5.6 & 18 \\
\hline Street & 93.0 & 87.4 & 4.2 & 67.2 & 55.6 & 2.8 & 66.1 & 16.8 & 696 \\
\hline Own ho me & 89.1 & 86.0 & 3.9 & 68.2 & 56.7 & 2.8 & 67.3 & 13.7 & 679 \\
\hline Highway & 96.5 & 91.2 & 3.8 & 78.4 & 62.5 & 2.4 & 77.2 & 10.6 & 491 \\
\hline \multicolumn{10}{|l|}{ Age group } \\
\hline $15-19$ & 84.9 & 66.0 & 2.9 & 43.4 & 21.7 & 1.7 & 31.1 & 1.9 & 106 \\
\hline $20-24$ & 87.8 & 82.2 & 3.7 & 50.9 & 38.7 & 2.6 & 50.2 & 10.3 & 426 \\
\hline $25-29$ & 92.6 & 88.5 & 3.8 & 68.5 & 55.5 & 2.6 & 67.7 & 13.3 & 743 \\
\hline $30-34$ & 96.2 & 93.6 & 4.3 & 84.6 & 71.9 & 2.8 & 84.2 & 18.8 & 531 \\
\hline $35-39$ & 95.9 & 93.5 & 4.4 & 89.1 & 75.8 & 2.9 & 88.5 & 22.4 & 339 \\
\hline $40+$ & 95.2 & 87.5 & 4.4 & 80.8 & 73.1 & 3.4 & 79.8 & 28.8 & 104 \\
\hline Total percent & 92.7 & 88.1 & 4.0 & 71.4 & 58.4 & 2.7 & 70.3 & 15.6 & \\
\hline Total (N) & 2,250 & 2,250 & $2,086 *$ & 2,250 & 2,250 & $1,606 * *$ & 2,250 & 2,250 & 2,250 \\
\hline
\end{tabular}

$* \mathrm{n}=2,086$ made at least one move in the last two years

$* * \mathrm{n}=1,606$ made at least one move across district in the last two years.

Source : Screening questionnaire 


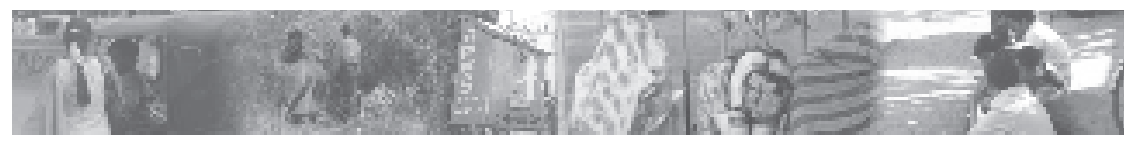

Table 2 : Volume of mobility by place of contact and age group

\begin{tabular}{|c|c|c|c|c|c|c|c|}
\hline & $\begin{array}{c}\text { East } \\
\text { Godavari } \\
\%\end{array}$ & $\begin{array}{c}\text { Krishna } \\
\%\end{array}$ & $\begin{array}{c}\text { Guntur } \\
\%\end{array}$ & $\begin{array}{c}\text { Hyderabad } \\
\%\end{array}$ & $\begin{array}{c}\text { Kurnool } \\
\%\end{array}$ & $\begin{array}{c}\text { Total } \\
\%\end{array}$ & $\begin{array}{c}\text { Total } \\
\mathbf{N}\end{array}$ \\
\hline \multicolumn{8}{|l|}{ Age group } \\
\hline $15-19$ & 33.3 & 44.4 & 40.6 & 6.3 & $25.8^{*}$ & 31.1 & 106 \\
\hline $20-24$ & 39.0 & 60.6 & 69.9 & 40.5 & 43.2 & 50.2 & 426 \\
\hline $25-29$ & 57.7 & 73.6 & 86.2 & 59.4 & 69.4 & 67.7 & 743 \\
\hline $30-34$ & 80.0 & 83.5 & 94.6 & 79.0 & 80.6 & 84.2 & 531 \\
\hline $35-39$ & 84.5 & 85.5 & 91.3 & 91.4 & 92.4 & 88.5 & 339 \\
\hline $40+$ & 64.0 & 79.2 & 93.1 & $66.7 *$ & 82.6 & 79.8 & 104 \\
\hline \multicolumn{8}{|l|}{ Place of contact } \\
\hline Brothel & 67.9 & 64.0 & 83.1 & 0.0 & 72.3 & 73.5 & 366 \\
\hline Hotel/lodge & 0.0 & 87.5 & 0.0 & 0.0 & $50.0^{*}$ & 83.3 & 18 \\
\hline Street & 64.7 & 66.3 & 76.7 & 54.8 & 69.1 & 66.1 & 696 \\
\hline Own home & 54.1 & 73.5 & 88.1 & 66.1 & 64.0 & 67.3 & 679 \\
\hline Highway & 71.0 & 79.1 & 86.3 & 53.8 & $75.0^{*}$ & 77.2 & 491 \\
\hline Total \% & 63.9 & 74.4 & 83.5 & 59.5 & 67.8 & 63.9 & \\
\hline Total (N) & 649 & 375 & 503 & 291 & 432 & & 2,250 \\
\hline
\end{tabular}

* based on less than 10 cases

Source : Screening questionnaire

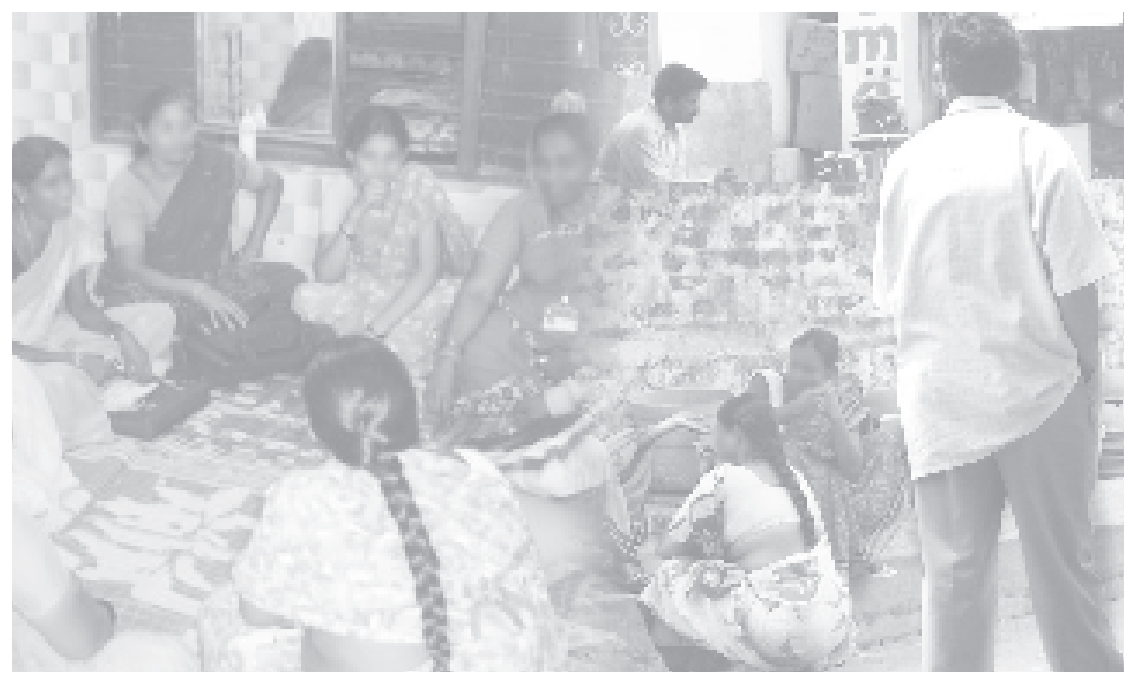




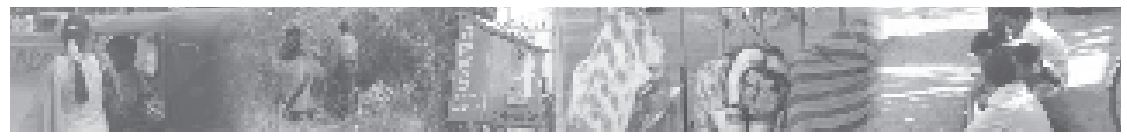

Table 3 : Jatara-related mobility and condom use by district

\begin{tabular}{|c|c|c|c|c|c|c|}
\hline & $\begin{array}{c}\text { East } \\
\text { Godavari } \\
\%\end{array}$ & $\begin{array}{c}\text { Krishna } \\
\%\end{array}$ & $\begin{array}{c}\text { Guntur } \\
\%\end{array}$ & $\begin{array}{c}\text { Hyderabad } \\
\%\end{array}$ & $\begin{array}{c}\text { Kurnool } \\
\%\end{array}$ & $\begin{array}{c}\text { Total } \\
\%\end{array}$ \\
\hline \multicolumn{7}{|l|}{$\begin{array}{l}\text { Visited Jatara in last } 12 \\
\text { months }\end{array}$} \\
\hline Yes & 37.5 & 38.4 & 43.4 & 44.1 & 60.6 & 44.2 \\
\hline No & 62.5 & 61.6 & 56.6 & 55.9 & 39.4 & 55.8 \\
\hline \multicolumn{7}{|l|}{ Visited in group \# } \\
\hline Group & 78.3 & 75.2 & 86.1 & 66.7 & 71.5 & 76.8 \\
\hline Alone & 21.7 & 24.8 & 13.9 & 33.3 & 28.5 & 23.2 \\
\hline \multicolumn{7}{|c|}{ Client type in Jatara (last visit) } \\
\hline $\begin{array}{l}\text { Male migrants from different } \\
\text { places }\end{array}$ & 67.6 & 39.6 & 42.6 & 65.8 & 65.3 & 56.0 \\
\hline $\begin{array}{l}\text { Male migrants of the same } \\
\text { district }\end{array}$ & 13.2 & 12.1 & 21 & 19.2 & 21.1 & 17.7 \\
\hline Local non-migrant men & 18.4 & 48.4 & 35.8 & 15.1 & 13.6 & 25.9 \\
\hline \multicolumn{7}{|l|}{$\begin{array}{l}\text { Condom use with clients in } \\
\text { last visit to Jatara }\end{array}$} \\
\hline With everyone & 59.3 & 71.4 & 70.2 & 50.7 & 64.6 & 64.3 \\
\hline With some people & 40.7 & 24.2 & 26.7 & 47.9 & 32.7 & 33.4 \\
\hline None & 0.0 & 3.3 & 3.1 & 1.4 & 2.7 & 2.1 \\
\hline Total \% & 100.0 & 100.0 & 100.0 & 100.0 & 100.0 & 100.0 \\
\hline
\end{tabular}

\# for those who visited Jatara locations

\# for those who visited Jatara locations in the last 12 months and had sex

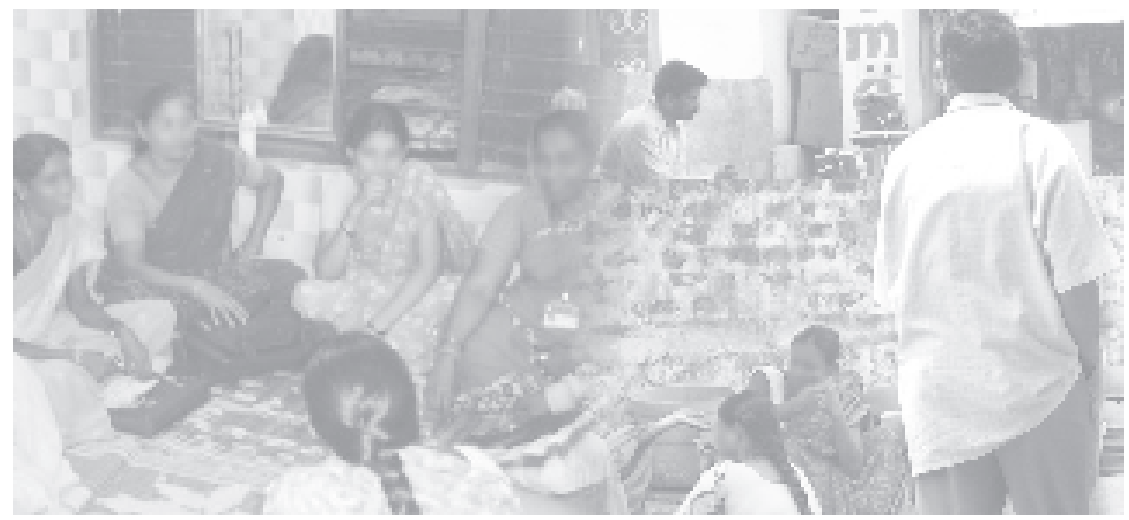




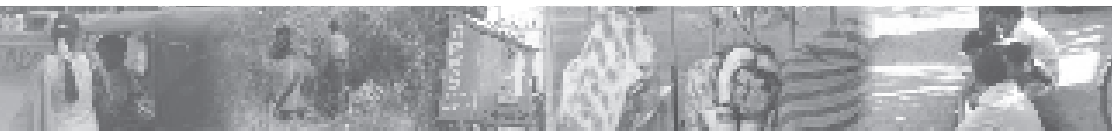

Table 3a: Name and duration of different Jataras in Andhra Pradesh

\begin{tabular}{lllll}
\hline District & Place of Jatara & Name of Jatara & Time of Jatara & Duration \\
\hline East Godavari & Tuni & Teerdhalu & January & 1 week \\
East Godavari & Peddapuram & Maridamma & July to August & 3 months \\
East Godavari & Near Peddapuram & Kandrakota & March to April & 1 month \\
East Godav ari & Bojjavaram & Balayogi therdhalu & January 14,15, 16 & 3 days \\
East Godavari & Payakarao peta & Kottamavasya & March & 1 week \\
Guntur & Kottakonda & Sivarathri & February & 3 days \\
Guntur & Peddapuram & Maridamma & Ashadhamasam & 5 days \\
Guntur & Nadakoduru & Shivarathri & February & 3 days \\
Guntur & Govada & Shivarathri & February & 3 days \\
Guntur & Kotappakonda & Sivaratri & February & 1 week \\
Krishna & Penuganchiprolu & Tirupatamma & February & 4 days \\
& & tirunalla & & \\
Krishna & Gunadala, & Mary Mata Tirunalla & February & 1 week \\
& Vijayawada & & & \\
Krishna & Penuganchi prolu & Mutyala ti runalla & February & 1 week \\
Kurnool & Mahanandi & Shivaratri & February & 1 week \\
Kurnool & Nandyala & Tikkaswamy & February & 3 days \\
Kurnool & & Mahankalamma & March 2 ${ }^{\text {nd }}$ week & 2 days \\
Warangal & Medaram & Sammakka Sarakka & February & 4 days \\
Hyderabad & Narayanaguda & Ganesh nimajjanam & September & 3 days \\
\hline
\end{tabular}

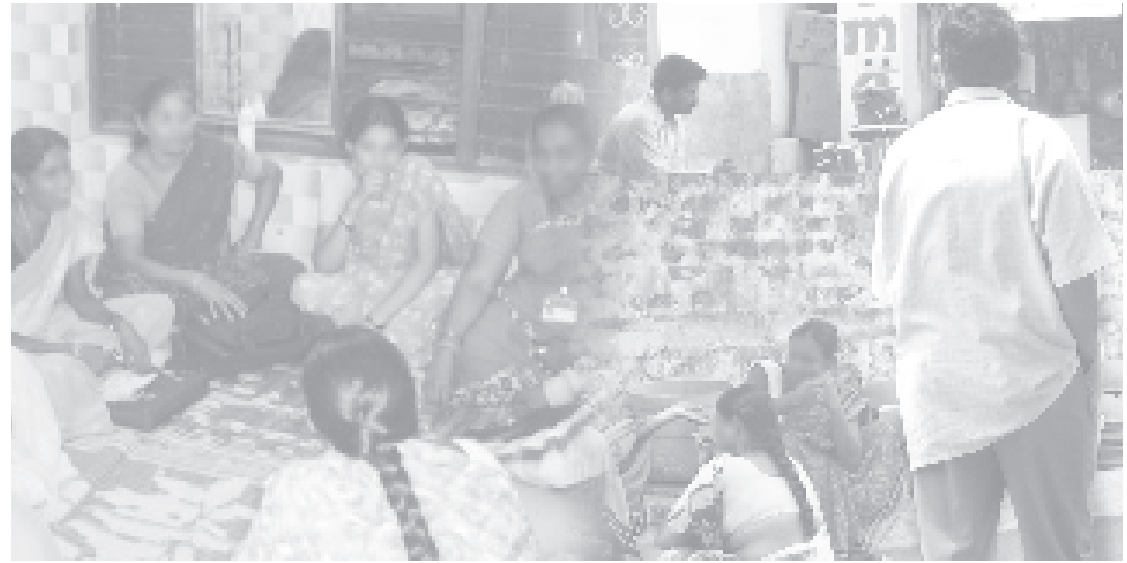


Table 4 : Socio-Economic and Demographic profile of mobile female sex workers ${ }^{\#}$ by district

\begin{tabular}{|c|c|c|c|c|c|c|c|}
\hline Characteristics & $\begin{array}{c}\text { East } \\
\text { Godavari } \\
\% \\
\end{array}$ & $\begin{array}{c}\text { Krishna } \\
\%\end{array}$ & $\begin{array}{c}\text { Guntur } \\
\%\end{array}$ & $\begin{array}{c}\text { Hyderabad } \\
\% \\
\end{array}$ & $\begin{array}{c}\text { Kurnool } \\
\%\end{array}$ & $\begin{array}{c}\text { Total } \\
\% \\
\end{array}$ & $\begin{array}{c}\text { Total } \\
\mathbf{N}\end{array}$ \\
\hline \multicolumn{8}{|l|}{ Age group } \\
\hline $18-24$ & 10.0 & 14.8 & 14.8 & 17.6 & 14.4 & 13.7 & 211 \\
\hline $25-29$ & 37.0 & 31.8 & 29.3 & 32.9 & 28.9 & 32.2 & 494 \\
\hline $30-34$ & 28.2 & 28.8 & 30.6 & 29.4 & 28.9 & 29.2 & 448 \\
\hline $35-39$ & 20.8 & 17.8 & 18.5 & 18.8 & 21.1 & 19.5 & 300 \\
\hline $40+$ & 4.1 & 6.8 & 6.8 & 1.2 & 6.7 & 5.4 & 83 \\
\hline \multicolumn{8}{|l|}{ Education } \\
\hline Illiterate & 52.7 & 29.7 & 42.9 & 47.6 & 51.4 & 45.4 & 697 \\
\hline < Primary (1-4 class $)$ & 12.9 & 19.4 & 15.5 & 8.2 & 13.0 & 14.2 & 218 \\
\hline Primary, (secondary 5-9 class) & 30.3 & 44.1 & 37.6 & 31.8 & 38.9 & 34.4 & 529 \\
\hline High school+ (10+ class $)$ & 4.1 & 6.8 & 4.0 & 12.4 & 6.7 & 5.9 & 92 \\
\hline \multicolumn{8}{|l|}{ Marital Status } \\
\hline Divorced/widowed/separated & 70.9 & 46.4 & 54.6 & 48.8 & 57.0 & 57.5 & 882 \\
\hline Unmarried & 13.3 & 6.5 & 7.0 & 11.2 & 4.9 & 8.7 & 134 \\
\hline Married & 15.8 & 47.1 & 38.3 & 40.0 & 38.0 & 33.8 & 519 \\
\hline \multicolumn{8}{|l|}{ Sources of Income } \\
\hline Sex work only & 51.4 & 20.2 & 17.8 & 38.8 & 21.8 & 30.5 & 468 \\
\hline $\begin{array}{l}\text { Sex work }+ \text { other sex related } \\
\text { work }\end{array}$ & 5.7 & 7.6 & 13.8 & 14.8 & 8.1 & 9.6 & 147 \\
\hline Sex work + other sources & 42.9 & 72.2 & 68.4 & 46.4 & 70.1 & 59.9 & 920 \\
\hline \multicolumn{8}{|l|}{$\begin{array}{l}\text { How much money } \\
\text { do you owe currently? }\end{array}$} \\
\hline None & 29.1 & 44.3 & 23.3 & 30.6 & 25.0 & 29.6 & 456 \\
\hline$<1,000$ & 30.3 & 19.5 & 37.8 & 39.4 & 26.8 & 30.8 & 472 \\
\hline $1,001-10,000$ & 19.6 & 18.7 & 17.0 & 8.2 & 28.9 & 19.2 & 295 \\
\hline $10,001-50,000$ & 19.6 & 13.7 & 20.3 & 20.6 & 18.3 & 18.6 & 286 \\
\hline $50,001+$ & 1.4 & 3.8 & 1.5 & 1.2 & 1.1 & 1.8 & 27 \\
\hline Total \% & 100.0 & 100.0 & 100.0 & 100.0 & 100.0 & 100.0 & \\
\hline Total (N) & 419 & 264 & 399 & 170 & 284 & & 1,536 \\
\hline
\end{tabular}

\# those who are at least 18 years old, have moved to at least two places in the last two years, and one of the two places is across district 


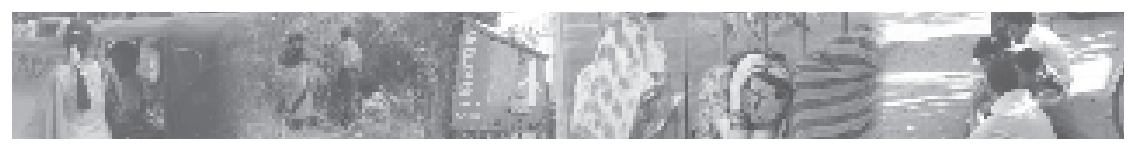

Table 5 : Reasons for entry into sex work

\begin{tabular}{lcccccc}
\hline & $\begin{array}{c}\text { East } \\
\text { Godavari } \\
\text { \% }\end{array}$ & $\begin{array}{c}\text { Krishna } \\
\mathbf{\%}\end{array}$ & $\begin{array}{c}\text { Guntur } \\
\mathbf{\%}\end{array}$ & $\begin{array}{c}\text { Hyderabad } \\
\mathbf{\%}\end{array}$ & $\begin{array}{c}\text { Kurnool } \\
\mathbf{\%}\end{array}$ & $\begin{array}{c}\text { Total } \\
\mathbf{\%}\end{array}$ \\
\hline $\begin{array}{l}\text { Entry into sex work } \\
\text { By force }\end{array}$ & 3.1 & 4.6 & 1.5 & 3.5 & 1.1 & 2.6 \\
$\quad \begin{array}{l}\text { Economic conditions with } \\
\text { debt }\end{array}$ & 33.4 & 34.0 & 41.4 & 47.1 & 39.1 & 38.1 \\
$\quad \begin{array}{l}\text { Economic conditions } \\
\text { without debt }\end{array}$ & 46.8 & 49.6 & 44.4 & 31.8 & 40.8 & 43.9 \\
$\quad \begin{array}{l}\text { Family tradition } \\
\text { Own choice/interest }\end{array}$ & 5.7 & 0.0 & 1.0 & 0.0 & 2.5 & 2.3 \\
\hline Total (N) & 11.0 & 11.8 & 11.8 & 17.6 & 16.5 & 13.1 \\
\hline
\end{tabular}

Table 6 : Mobile female sex workers' use of tobacco, alcohol, and drugs in the last month

\begin{tabular}{|c|c|c|c|c|c|c|}
\hline & $\begin{array}{c}\text { East } \\
\text { Godavari } \\
\%\end{array}$ & $\begin{array}{c}\text { Krishna } \\
\%\end{array}$ & $\begin{array}{c}\text { Guntur } \\
\%\end{array}$ & $\begin{array}{c}\text { Hyderabad } \\
\%\end{array}$ & $\begin{array}{c}\text { Kurnool } \\
\%\end{array}$ & $\begin{array}{c}\text { Total } \\
\%\end{array}$ \\
\hline Used tobacco & 61.3 & 68.6 & 64.9 & 71.2 & 66.2 & 65.5 \\
\hline Used alcohol & 89.5 & 83.0 & 74.7 & 94.7 & 71.8 & 81.8 \\
\hline Used drugs & 0.2 & 2.3 & 0.5 & 1.2 & 1.1 & 0.9 \\
\hline Total (N) & 419 & 264 & 399 & 170 & 284 & 1,536 \\
\hline
\end{tabular}

Table 7 : Percent of mobile female sex workers who have a bank account, separate money, and cell phone

\begin{tabular}{lcccccc}
\hline & $\begin{array}{c}\text { East } \\
\text { Godavari } \\
\mathbf{\%}\end{array}$ & $\begin{array}{c}\text { Krishna } \\
\mathbf{\%}\end{array}$ & $\begin{array}{c}\text { Guntur } \\
\mathbf{\%}\end{array}$ & $\begin{array}{c}\text { Hyderabad } \\
\mathbf{\%}\end{array}$ & $\begin{array}{c}\text { Kurnool } \\
\mathbf{\%}\end{array}$ & $\begin{array}{c}\text { Total } \\
\mathbf{\%}\end{array}$ \\
\hline $\begin{array}{l}\text { Women have separate } \\
\text { bank/post office accounts }\end{array}$ & 29.6 & 34.4 & 37.3 & 62.4 & 33.1 & 36.7 \\
$\quad \begin{array}{l}\text { Allowed to have money set } \\
\text { aside }\end{array}$ & 94.0 & 92.0 & 97.0 & 95.9 & 92.6 & 94.4 \\
$\quad$ Have cell phones & 36.3 & 32.1 & 26.8 & 71.8 & 22.2 & 34.4 \\
\hline Total N & $\mathbf{4 1 9}$ & $\mathbf{2 6 4}$ & $\mathbf{3 9 9}$ & $\mathbf{1 7 0}$ & $\mathbf{2 8 4}$ & $\mathbf{1 , 5 3 6}$ \\
\hline
\end{tabular}




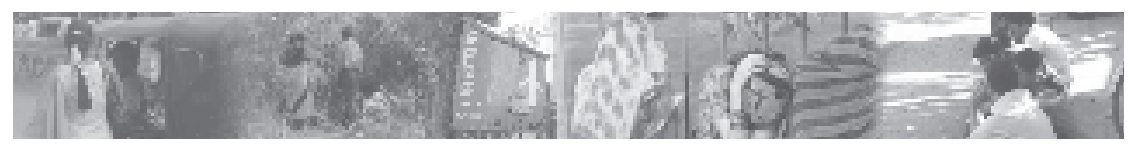

Table 8 : Percent of mobile female sex workers who experienced violence in the last year and perpetrators of violence

\begin{tabular}{lcccccc}
\hline & $\begin{array}{c}\text { East } \\
\text { Godavari } \\
\text { \% }\end{array}$ & $\begin{array}{c}\text { Krishna } \\
\mathbf{\%}\end{array}$ & $\begin{array}{c}\text { Guntur } \\
\mathbf{\%}\end{array}$ & $\begin{array}{c}\text { Hyderabad } \\
\mathbf{\%}\end{array}$ & $\begin{array}{c}\text { Kurnool } \\
\mathbf{\%}\end{array}$ & $\begin{array}{c}\text { Total } \\
\mathbf{\%}\end{array}$ \\
\hline $\begin{array}{l}\text { Experienced physical } \\
\text { violence in the last year }\end{array}$ & & & & & & \\
$\quad \begin{array}{l}\text { Often } \\
\text { Sometimes }\end{array}$ & 7.2 & 3.4 & 1.3 & 10.0 & 7.7 & 5.4 \\
$\quad$ Rarely & 12.9 & 9.1 & 6.0 & 7.1 & 10.2 & 9.3 \\
$\quad$ Never & 34.3 & 12.5 & 16.8 & 24.1 & 15.5 & 18.7 \\
\hline Total \% & 55.6 & 74.9 & 75.9 & 58.8 & 66.5 & 66.6 \\
\hline Total (N) & $\mathbf{1 0 0 . 0}$ & $\mathbf{1 0 0 . 0}$ & $\mathbf{1 0 0 . 0}$ & $\mathbf{1 0 0 . 0}$ & $\mathbf{1 0 0 . 0}$ & $\mathbf{1 0 0 . 0}$ \\
\hline Source of violence\# & $\mathbf{4 1 9}$ & $\mathbf{2 6 4}$ & $\mathbf{3 9 9}$ & $\mathbf{1 7 0}$ & $\mathbf{2 8 4}$ & $\mathbf{1 , 5 3 6}$ \\
$\quad$ Police & 30.8 & 23.1 & 21.9 & 15.7 & 15.4 & 23.2 \\
$\quad$ Clients & 47.3 & 47.7 & 47.9 & 44.3 & 54.9 & 48.4 \\
$\quad$ Rowdies & 8.2 & 9.2 & 5.2 & 15.7 & 2.2 & 7.7 \\
$\quad$ Other & 13.7 & 20.0 & 25.0 & 24.3 & 27.5 & 20.6 \\
\hline Total \% & $\mathbf{1 0 0 . 0}$ & $\mathbf{1 0 0 . 0}$ & $\mathbf{1 0 0 . 0}$ & $\mathbf{1 0 0 . 0}$ & $\mathbf{1 0 0 . 0}$ & $\mathbf{1 0 0 . 0}$ \\
\hline Sample (N) & $\mathbf{1 8 2}$ & $\mathbf{6 5}$ & $\mathbf{9 6}$ & $\mathbf{7 0}$ & $\mathbf{9 1}$ & $\mathbf{5 0 4}$ \\
\hline
\end{tabular}

\# among those who experienced violence

Table 9 : Percent of mobile female sex workers exposed to media in the last month

\begin{tabular}{|c|c|c|c|c|c|c|}
\hline & $\begin{array}{c}\text { East } \\
\text { Godavari } \\
\%\end{array}$ & $\begin{array}{c}\text { Krishna } \\
\%\end{array}$ & $\begin{array}{c}\text { Guntur } \\
\%\end{array}$ & $\begin{array}{c}\text { Hyderabad } \\
\%\end{array}$ & $\begin{array}{c}\text { Kurnool } \\
\%\end{array}$ & $\begin{array}{c}\text { Total } \\
\%\end{array}$ \\
\hline Read newspaper/magazine & 19.3 & 30.3 & 27.3 & 36.5 & 24.6 & 26.2 \\
\hline Listened to radio & 13.4 & 31.8 & 32.8 & 76.5 & 37.3 & 33.0 \\
\hline Watched movie/television & 99.3 & 98.1 & 97.5 & 100.0 & 98.9 & 98.6 \\
\hline Total N & 419 & 264 & 399 & 170 & 284 & 1,536 \\
\hline
\end{tabular}




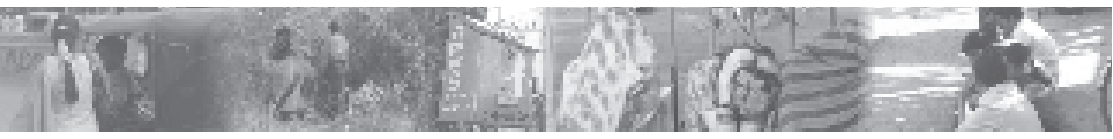

Table 10 : HIV vulnerability of mobile female sex workers by district

\begin{tabular}{|c|c|c|c|c|c|c|}
\hline & $\begin{array}{c}\text { East } \\
\text { Godavari } \\
\%\end{array}$ & $\begin{array}{c}\text { Krishna } \\
\%\end{array}$ & $\begin{array}{c}\text { Guntur } \\
\%\end{array}$ & $\begin{array}{c}\text { Hyderabad } \\
\%\end{array}$ & $\begin{array}{c}\text { Kurnool } \\
\%\end{array}$ & $\begin{array}{c}\text { Total } \\
\%\end{array}$ \\
\hline \multicolumn{7}{|l|}{ Consistent condom use with } \\
\hline Occasional clients & 86.1 & 88.1 & 85.3 & 85.6 & 72.7 & 83.7 \\
\hline Regular clients & 60.9 & 83.7 & 79.3 & 66.5 & 69.5 & 71.7 \\
\hline With occasional/regular clients & 55.8 & 78.4 & 76.4 & 63.5 & 65.5 & 67.7 \\
\hline Nonpaying partner & 32.7 & 62.3 & 59.3 & 34.9 & 32.7 & 45.6 \\
\hline Any client & 52.2 & 71.9 & 72.2 & 54.1 & 57.7 & 62.0 \\
\hline Had STI symptoms ${ }^{2}$ & 78.5 & 67.0 & 76.4 & 71.8 & 72.5 & 74.2 \\
\hline $\begin{array}{l}\text { Had STI symptoms and } \\
\text { continued to have sex }\end{array}$ & 28.4 & 25.8 & 27.3 & 27.1 & 27.8 & 27.4 \\
\hline $\begin{array}{l}\text { Experienced sexual violence and } \\
\text { did not use a condom }\end{array}$ & 19.8 & 27.3 & 17.5 & 30.0 & 19.7 & 21.6 \\
\hline \multicolumn{7}{|l|}{ Self -perception of HIV risk } \\
\hline High & 18.6 & 24 & 21.8 & 18.8 & 23.6 & 21.3 \\
\hline Moderate & 35.6 & 32.3 & 30.6 & 44.1 & 37.7 & 35.1 \\
\hline Low & 45.8 & 43.6 & 47.6 & 37.1 & 38.7 & 43.6 \\
\hline Tested for HIV & 97.1 & 93.5 & 96.0 & 97.1 & 94.4 & 95.6 \\
\hline Went for voluntary testing of HIV & 29.5 & 40.2 & 36.5 & 34.5 & 28.4 & 33.5 \\
\hline Total $\mathbf{N}$ & 419 & 264 & 399 & 170 & 284 & 1536 \\
\hline
\end{tabular}

${ }^{1}$ Consistent condom use computed taking the weighted average of the clients that she had sex with type of partners in the last one week, one day and last time sex.

2 percentage of sex workers had any of the following symptoms in the last 6 months: Excessive vaginal discharge, Foul smelling discharge, Ulcers /sores in genital area, Swelling in groin area, Pain during intercourse, Itching in genital area, Pain in lower abdomen, Frequent/sometimes painful urination

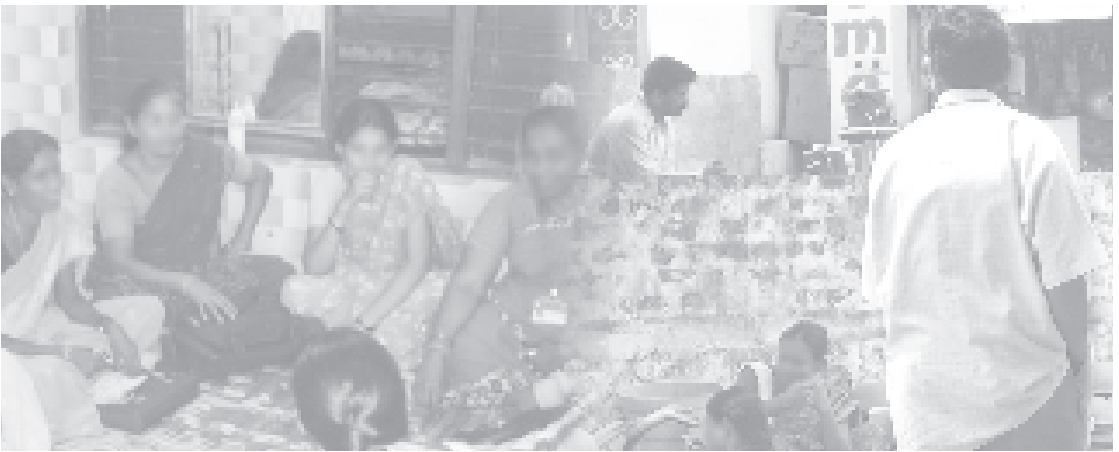


Table 11 : Availability and ability to use condoms

\begin{tabular}{|c|c|c|c|c|c|c|}
\hline & $\begin{array}{c}\text { East } \\
\text { Godavari } \\
\% \\
\end{array}$ & $\begin{array}{c}\text { Krishna } \\
\%\end{array}$ & $\begin{array}{c}\text { Guntur } \\
\%\end{array}$ & $\begin{array}{c}\text { Hyderabad } \\
\% \\
\end{array}$ & $\begin{array}{c}\text { Kurnool } \\
\%\end{array}$ & $\begin{array}{c}\text { Total } \\
\%\end{array}$ \\
\hline $\begin{array}{l}\% \text { reporting non-use of condoms due } \\
\text { to non -availability }\end{array}$ & 35.3 & 27.8 & 26.6 & 38.8 & 37.3 & 32.5 \\
\hline $\begin{array}{l}\% \text { reporting non-use of condoms due } \\
\text { to clients refusal }\end{array}$ & 28.2 & 29.7 & 27.6 & 34.1 & 43.7 & 31.8 \\
\hline $\begin{array}{l}\% \text { reporting use of condoms after } \\
\text { successful negotiation with a client }\end{array}$ & 59.4 & 57.4 & 56.8 & 58.8 & 69.4 & 60.2 \\
\hline Tot al N & 419 & 264 & 399 & 170 & 284 & 1536 \\
\hline
\end{tabular}

Table 12 : Ability to use and the actual use of condoms among mobile FSWs

\begin{tabular}{|c|c|c|c|c|c|c|}
\hline \multirow[t]{2}{*}{ Characteristics } & \multicolumn{5}{|c|}{ Consistent condom use } & \multirow{2}{*}{$\begin{array}{c}\text { Total } \\
\text { N }\end{array}$} \\
\hline & $\begin{array}{l}\text { Occasional } \\
\text { clients } \\
\%\end{array}$ & $\begin{array}{l}\text { Regular } \\
\text { clients } \\
\%\end{array}$ & $\begin{array}{c}\text { Occasional/Reg } \\
\text { ular Client } \\
\%\end{array}$ & $\begin{array}{l}\text { Non-paying } \\
\text { Partners } \\
\%\end{array}$ & $\begin{array}{c}\text { Any partner } 1 \\
\%\end{array}$ & \\
\hline \multicolumn{7}{|c|}{$\begin{array}{l}\text { Ability to use condom } \\
\text { Have there been times condom } \\
\text { not available and hence not } \\
\text { used? }\end{array}$} \\
\hline Yes & 67.7 & 60.2 & 53.7 & 45.3 & 48.3 & 499 \\
\hline No & 91.5 & 77.4 & 74.5 & 45.9 & 68.7 & 1036 \\
\hline \multicolumn{7}{|c|}{$\begin{array}{l}\text { Have there been times when } \\
\text { customer refused to use condom } \\
\text { and you agreed? }\end{array}$} \\
\hline Yes & 63.9 & 57.4 & 50.8 & 43.7 & 45.4 & 488 \\
\hline No & 93.0 & 78.5 & 75.6 & 47.5 & 69.8 & 1047 \\
\hline \multicolumn{7}{|c|}{$\begin{array}{l}\text { Have there been times when } \\
\text { customer refused to use condom } \\
\text { but you convinced him to use it? }\end{array}$} \\
\hline Yes & 78.7 & 65.8 & 60.6 & 42.5 & 55.0 & 923 \\
\hline No & 91.4 & 80.7 & 78.6 & 51.9 & 72.5 & 611 \\
\hline Total \% & 83.7 & 71.7 & 67.8 & 45.6 & 62.0 & \\
\hline Total N & 1520 & 1515 & 1533 & 703 & 1533 & \\
\hline
\end{tabular}

${ }^{1}$ Consistent condom use computed taking the weighted average of the clients that she had sex with

${ }^{2}$ percentage of sex workers had any of the following symptoms in the last 6 months: Excessive vaginal discharge, Foul smelling discharge, Ulcers /sores in genital area, Swelling in groin area, Pain during intercourse, Itching in genital area, Pain in lower abdomen, Frequent/sometimes painful urination

${ }^{3}$ percentage refers to all those sex workers who had at least one of the STI symptoms and continue to have sex out of the total female sex workers interviewed

${ }^{4}$ percentage refers to the any of the partners beat /physically force you to have sex and not used condom during that time out of the total female sex workers interviewed

${ }^{5}$ percentage refers to the self perception of risk to HIV 


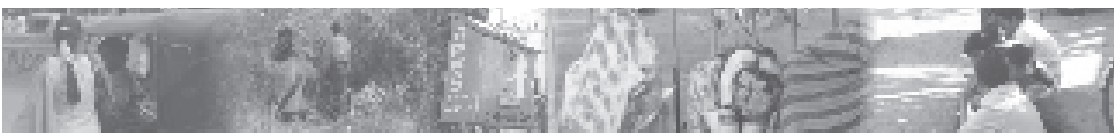

Table 13: Socio- economic insecurity and HIV vulnerability

\begin{tabular}{|c|c|c|c|c|c|c|c|c|c|c|c|}
\hline \multirow[t]{2}{*}{ Characteristics } & \multicolumn{5}{|c|}{ \% mobile FSWs who consistently use condom with } & \multirow{2}{*}{$\begin{array}{l}\% \text { had STI } \\
\text { symptoms } \\
\text { in the last } \\
6 \text { months }{ }^{2}\end{array}$} & \multirow{2}{*}{$\begin{array}{l}\text { \% who have } \\
\text { STI } \\
\text { symptoms } \\
\text { and continue } \\
\text { to have sex }\end{array}$} & \multirow{2}{*}{$\begin{array}{c}\% \text { experienced } \\
\text { sexual violence } \\
\text { and not used } \\
\text { condom }{ }^{4}\end{array}$} & \multicolumn{2}{|c|}{$\begin{array}{c}\text { HIV Risk } \\
\text { perception }^{5}\end{array}$} & \multirow[t]{2}{*}{$\begin{array}{c}\text { Total } \\
\mathrm{N}\end{array}$} \\
\hline & $\begin{array}{l}\text { Occasional } \\
\text { clients }\end{array}$ & $\begin{array}{l}\text { Regular } \\
\text { clients }\end{array}$ & $\begin{array}{c}\text { Occasional } \\
\text { /Regular } \\
\text { Partner }\end{array}$ & $\begin{array}{c}\text { Non - } \\
\text { paying } \\
\text { partners }\end{array}$ & $\begin{array}{c}\text { Any } \\
\text { partner }^{1}\end{array}$ & & & & High & Moderate & \\
\hline \multicolumn{12}{|l|}{$\begin{array}{l}\text { Have been beaten in } \\
\text { the last one year }\end{array}$} \\
\hline Yes & 79.7 & 59.6 & 56.0 & 26.1 & 48.5 & 82.9 & 35.9 & 31.2 & 27.6 & 37.1 & 504 \\
\hline No & 85.7 & 77.7 & 73.5 & 58.3 & 68.6 & 69.9 & 23.3 & 17.0 & 18.2 & 34.0 & 1031 \\
\hline \multicolumn{12}{|l|}{$\begin{array}{l}\text { Alcohol use in the last } \\
\text { one month }\end{array}$} \\
\hline Yes & 81.9 & 68.8 & 81.7 & 42.5 & 58.6 & 76.7 & 30.9 & 23.9 & 20.8 & 36.7 & 1257 \\
\hline No & 92.0 & 85.0 & 64.6 & 66.3 & 77.4 & 62.7 & 11.8 & 11.5 & 23.7 & 27.7 & 278 \\
\hline \multicolumn{12}{|l|}{ Source of Income } \\
\hline Sex work only & 85.7 & 73.0 & 68.6 & 48.0 & 66.3 & 70.3 & 22.9 & 20.5 & 12.2 & 35.7 & 461 \\
\hline $\mathrm{SW}+\mathrm{SW}$ related & 90.5 & 84.1 & 82.3 & 46.6 & 72.8 & 63.9 & 25.9 & 26.5 & 21.1 & 21.1 & 147 \\
\hline $\mathrm{SW}+$ non $-\mathrm{SW}$ related & 81.7 & 69.1 & 65.0 & 45.1 & 58.2 & 77.8 & 30.0 & 21.4 & 26.0 & 37.0 & 912 \\
\hline \multicolumn{12}{|l|}{ Owe money } \\
\hline None & 88.4 & 76.5 & 72.4 & 49.6 & 66.4 & 57.2 & 13.7 & 16.2 & 15.4 & 26.9 & 439 \\
\hline$<1000$ & 82.0 & 67.9 & 64.2 & 48.4 & 58.8 & 76.1 & 35.2 & 24.8 & 27.8 & 42.4 & 470 \\
\hline $1001-10000$ & 72.7 & 61.1 & 55.3 & 31.8 & 51.2 & 86.1 & 24.7 & 20.7 & 25.4 & 30.5 & 293 \\
\hline $10001-50000$ & 90.1 & 79.7 & 76.9 & 51.6 & 69.9 & 85.7 & 39.5 & 25.5 & 16.1 & 38.8 & 286 \\
\hline $50001+$ & 88.9 & 92.3 & 88.9 & $70.0^{*}$ & 77.8 & 74.1 & $25.9^{*}$ & 25.9 & $18.5^{*}$ & 55.6 & 26 \\
\hline
\end{tabular}

\section{Marital Status}

Divorced /widowed

/separated /deserted

Unmarried

$63.4 \quad 40.6$

$\begin{array}{lll}56.9 & 80.7 \quad 31.5\end{array}$

Married

$90.3 \quad 86.6 \quad 80.6$

\begin{tabular}{|c|c|c|c|c|c|c|c|c|c|c|c|}
\hline Total \% & 83.7 & 71.7 & $\begin{array}{ll}67.8 \\
\end{array}$ & 45.6 & 62.0 & 74.2 & 27.4 & 21.6 & 21.3 & 35.0 & \\
\hline Total N & 1520 & 1515 & 1533 & 703 & 1533 & 1536 & 1536 & 1536 & 1536 & 1536 & 1536 \\
\hline
\end{tabular}

* based on less than 10 cases

${ }^{1}$ Consistent condom use computed taking the weighted average of the clients that she had sex with

${ }^{2}$ percentage of sex workers had any of the following symptoms in the last 6 months: Excessive vaginal discharge, Foul smelling discharge, Ulcers /sores in genital area, Swelling in groin area, Pain during intercourse, Itching in genital area, Pain in lower abdomen, Frequent/sometimes painful urination

${ }^{3}$ percentage refers to all those sex workers who had at least one of the STI symptoms and continue to have sex out of the total female sex workers interviewed

${ }^{4}$ percentage refers to the any of the partners beat /physically force you to have sex and not used condom during that time out of the total female sex workers interviewed

${ }^{5}$ percentage refers to the self perception of risk to HIV

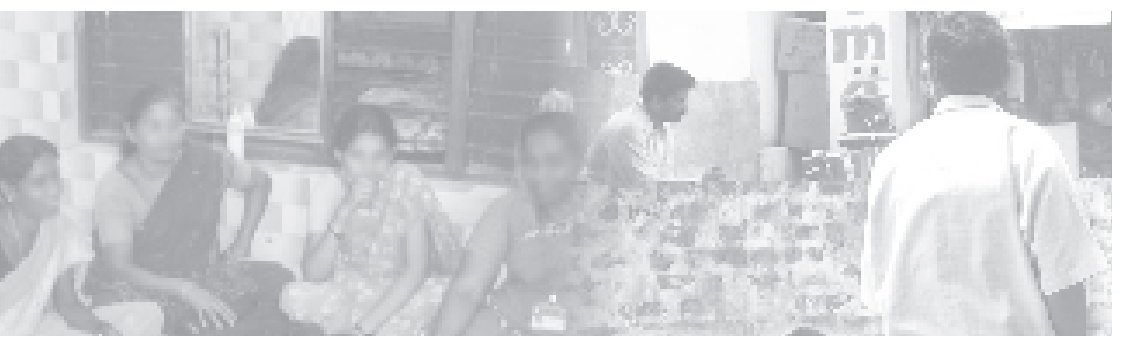




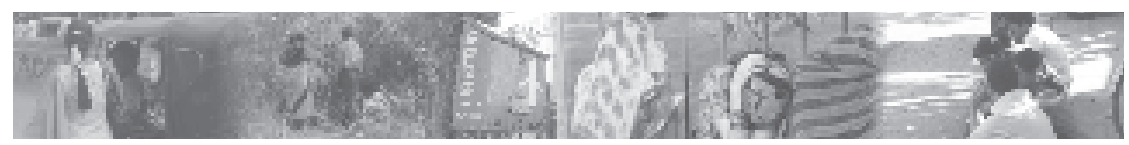

Table 14: Mobility and HIV Risk

\begin{tabular}{|c|c|c|c|c|c|c|c|c|c|c|c|}
\hline \multirow[t]{2}{*}{$\begin{array}{l}\text { Mobility /Migration } \\
\text { characteristics }\end{array}$} & \multicolumn{5}{|c|}{$\%$ mobile FSWs who consistently used condom with } & \multirow{2}{*}{$\begin{array}{l}\% \text { had STI } \\
\text { symptoms } \\
\text { in the last } \\
6 \text { months }^{2}\end{array}$} & \multirow{2}{*}{$\begin{array}{l}\text { \% who have } \\
\text { STI } \\
\text { symptoms } \\
\text { and continue } \\
\text { to have sex }\end{array}$} & \multirow{2}{*}{$\begin{array}{l}\% \text { experienced } \\
\text { sexual violence } \\
\text { and not used } \\
\text { condom }^{4}\end{array}$} & \multicolumn{2}{|c|}{$\begin{array}{r}\text { HIV Risk } \\
\text { perception }^{5}\end{array}$} & \multirow[t]{2}{*}{$\begin{array}{c}\text { Total } \\
\text { N }\end{array}$} \\
\hline & $\begin{array}{l}\text { Occasional } \\
\text { clients }\end{array}$ & $\begin{array}{l}\text { Regular } \\
\text { clients }\end{array}$ & $\begin{array}{c}\text { Non - } \\
\text { paying } \\
\text { partners }\end{array}$ & $\begin{array}{c}\text { Occasional } \\
\text { /Regular } \\
\text { Partner }\end{array}$ & $\begin{array}{c}\text { Any } \\
\text { client }^{1}\end{array}$ & & & & High & Moderate & \\
\hline \multicolumn{12}{|l|}{ Number of moves } \\
\hline 1-2 places & 87.0 & 89.9 & 65.4 & 80.6 & 74.2 & 58.9 & 22.6 & 22.6 & 8.1 & 33.1 & 123 \\
\hline 3-4 places & 86.4 & 71.8 & 43.5 & 68.4 & 62.5 & 71.9 & 24.7 & 21.3 & 17.3 & 35.7 & 789 \\
\hline $5+$ places & 79.5 & 68.0 & 45.9 & 64.2 & 58.9 & 80.2 & 31.9 & 21.8 & 29.1 & 34.6 & 609 \\
\hline \multicolumn{12}{|l|}{$\begin{array}{l}\text { Number of moves } \\
\text { across districts }\end{array}$} \\
\hline $1-2$ districts & 85.4 & 68.6 & 36.3 & 63.9 & 57.6 & 71.5 & 28.3 & 20.7 & 16.9 & 36.7 & 779 \\
\hline $3+$ districts & 81.9 & 74.7 & 52.9 & 71.7 & 66.5 & 76.9 & 26.6 & 22.6 & 25.9 & 33.3 & 741 \\
\hline \multicolumn{12}{|l|}{ Visit to Jatara } \\
\hline No & 86.1 & 72.5 & 45.9 & 68.2 & 63.4 & 68.6 & 21.4 & 15.5 & 20.2 & 34.0 & 848 \\
\hline Alone & 87.2 & 65.8 & 53.2 & 62.4 & 57.3 & 75.8 & 12.1 & 25.5 & 28.7 & 22.9 & 156 \\
\hline Group & 78.7 & 72.1 & 43.6 & 68.5 & 61.0 & 82.7 & 41.8 & 30.5 & 20.9 & 40.5 & 517 \\
\hline \multicolumn{12}{|l|}{ Visit to MMW Places } \\
\hline No & 84.4 & 70.5 & 43.3 & 66.5 & 61.6 & 72.1 & 24.4 & 20.2 & 20.2 & 35.6 & 1308 \\
\hline Alone & 81.4 & 72.7 & 65.5 & 72.7 & 68.2 & 81.8 & 31.8 & 22.7 & 40.9 & 27.3 & 44 \\
\hline Group & 79.4 & 80.0 & 51.8 & 74.9 & 63.4 & 86.9 & 47.5 & 31.1 & 24.6 & 32.8 & 183 \\
\hline \multicolumn{12}{|l|}{$\begin{array}{l}\text { Duration of stay in the } \\
\text { current place }\end{array}$} \\
\hline$<=1$ year & 84.0 & 81.0 & 74.8 & 75.6 & 71.8 & 80.9 & 26.8 & 21.1 & 26.8 & 31.1 & 209 \\
\hline $1-2$ years & 77.8 & 56.3 & 38.8 & 51.0 & 48.7 & 84.5 & 19.4 & 22.6 & 38.7 & 25.8 & 155 \\
\hline 2-3 years & 82.4 & 58.8 & 35.3 & 55.4 & 51.4 & 82.0 & 15.1 & 16.5 & 36.0 & 24.5 & 139 \\
\hline 3-4 years & 86.7 & 51.8 & 19.6 & 51.8 & 48.2 & 73.5 & 16.9 & 22.9 & 30.1 & 16.9 & 83 \\
\hline 4-5 years & 81.3 & 69.1 & 32.9 & 64.4 & 59.6 & 76.0 & 27.4 & 28.4 & 14.9 & 37.0 & 208 \\
\hline $5+$ years & 85.5 & 77.7 & 45.1 & 74.1 & 66.2 & 68.4 & 32.8 & 20.5 & 14.2 & 41.6 & 742 \\
\hline
\end{tabular}

Person accompanied to migrate to the current place

\begin{tabular}{|c|c|c|c|c|c|c|c|c|c|c|c|}
\hline Self & 87.8 & 77.3 & 47.9 & 72.7 & 67.6 & 69.2 & 17.4 & 24.0 & 21.4 & 24.5 & 417 \\
\hline Husband/Parents & 82.5 & 69.8 & 42.4 & 66.2 & 60.5 & 73.0 & 30.2 & 19.9 & 20.4 & 38.1 & 840 \\
\hline Female friend & 80.4 & 71.7 & 51.5 & 66.9 & 59.7 & 89.6 & 39.0 & 26.0 & 23.4 & 47.4 & 153 \\
\hline Madam/Pi mp & 75.4 & 59.0 & 68.4 & 52.5 & 52.5 & 83.6 & 31.1 & 24.6 & 14.8 & 42.6 & 61 \\
\hline Client & 97.2 & 83.8 & 63.6 & 83.8 & 73.0 & 83.8 & 29.7 & 13.5 & 37.8 & 29.0 & 36 \\
\hline Others* & $62.5^{*}$ & 25.0 & 0.0 & $25.0^{*}$ & 0.0 & 75.0 & 12.5 & 25.0 & 62.5 & 12.5 & 8 \\
\hline Total \% & 83.7 & 71.7 & 45.6 & 67.7 & 62.0 & 74.3 & 27.4 & 21.6 & 21.3 & 35.0 & \\
\hline Total N & 1520 & 1515 & 703 & 1533 & 1533 & 1536 & 1536 & 1536 & 1536 & 1536 & \\
\hline
\end{tabular}

* based on less than 10 cases

${ }^{1}$ Consistent condom use computed taking the weighted average of the clients that she had sex with

${ }^{2}$ percentage of sex workers had any of the following symptoms in the last 6 months: Excessive vaginal discharge, Foul smelling

discharge, Ulcers /sores in genital area, Swelling in groin area, Pain during intercourse, Itching in genital area, Pain in lower abdomen, Frequent/sometimes painful urination abdomen, Frequent/sometimes painful urination

${ }^{3}$ percentage refers to all those sex workers who had at least one of the STI symptoms and continue to have sex out of the total

female sex workers interviewed

${ }_{4}^{4}$ percentage refers to the any of the partners beat/physically force you to have sex and not used condom during that time out of the

total female sex workers interviewed

5 percentage refers to the self perception of risk to HIV 


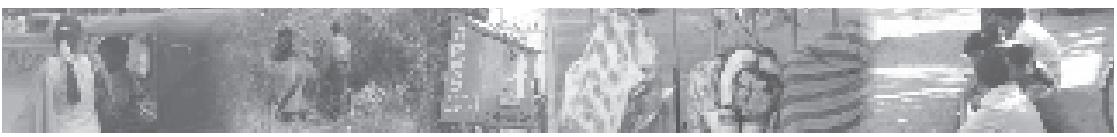

Table 15: HIV Risk according to mobility within migration

\begin{tabular}{|c|c|c|c|c|c|c|c|c|c|c|c|}
\hline \multirow[t]{2}{*}{$\begin{array}{l}\text { Migration and Mobility } \\
\text { characteristics }\end{array}$} & \multicolumn{5}{|c|}{$\%$ mobile FSWs who consistently used condom with } & \multirow{2}{*}{$\begin{array}{c}\% \text { had STI } \\
\text { s ymptoms } \\
\text { in the last } 6 \\
\text { months }^{2}\end{array}$} & \multirow{2}{*}{$\begin{array}{l}\% \text { who have } \\
\text { STI } \\
\text { symptoms } \\
\text { and continue } \\
\text { to have sex }{ }^{3}\end{array}$} & \multirow{2}{*}{$\begin{array}{c}\% \\
\text { experienced } \\
\text { sexual } \\
\text { violence and } \\
\text { not used } \\
\text { condom }^{4} \\
\end{array}$} & \multicolumn{2}{|c|}{$\begin{array}{c}\text { HIV Risk } \\
\text { perception }^{5}\end{array}$} & \multirow[t]{2}{*}{ Total N } \\
\hline & $\begin{array}{c}\text { Occasional } \\
\text { clients }\end{array}$ & $\begin{array}{l}\text { Regular } \\
\text { clients }\end{array}$ & $\begin{array}{c}\text { Non- } \\
\text { paying }\end{array}$ & $\begin{array}{c}\text { Occasional } \\
\text { /Regular } \\
\text { Partner }\end{array}$ & $\begin{array}{c}\text { Any } \\
\text { client }^{1}\end{array}$ & & & & High & Moderate & \\
\hline \multicolumn{12}{|l|}{ Migrated in $<=1$ year } \\
\hline 1-3 places & 87.3 & 83.8 & 71.9 & 79.2 & 73.6 & 68.1 & 22.2 & 11.1 & 20.8 & 29.2 & 72 \\
\hline $4+$ places & 82.2 & 79.6 & 75.8 & 73.7 & 70.8 & 87.6 & 29.2 & 26.3 & 29.9 & 32.1 & 137 \\
\hline \multicolumn{12}{|l|}{$\begin{array}{l}\text { Migrated for more than } 1 \\
\text { year but }<=2 \text { years }\end{array}$} \\
\hline 1-3 places & 82.1 & 73.7 & 37.5 & 69.2 & 61.5 & 69.2 & 15.4 & 20.5 & 23.1 & 25.6 & 39 \\
\hline $4+$ places & 76.3 & 50.4 & 39.1 & 44.8 & 44.3 & 89.7 & 20.7 & 23.3 & 44 & 25.9 & 116 \\
\hline \multicolumn{12}{|l|}{$\begin{array}{l}\text { Migrated for more than } 2 \\
\text { years but }<=3 \text { years }\end{array}$} \\
\hline 1-3 places & 91.7 & 82.9 & 60 & 71.1 & 67.6 & 65.8 & 13.2 & 28.9 & 31.6 & 31.6 & 38 \\
\hline $4+$ places & 79.0 & 50.5 & 30 & 49.5 & 45.5 & $8_{8.1}$ & 15.8 & 11.9 & 37.6 & 21.8 & 101 \\
\hline \multicolumn{12}{|l|}{$\begin{array}{l}\text { Migrated for more than } 3 \\
\text { years but }<=4 \text { years }\end{array}$} \\
\hline 1-3 places & 91.3 & 78.3 & 33.3 & 78.3 & 69.6 & 47.8 & 13 & 26.1 & 17.4 & 8.7 & 23 \\
\hline $4+$ places & 85.0 & 41.7 & 16.2 & 41.7 & 40 & 83.3 & 18.3 & 21.7 & 35.0 & 20 & 60 \\
\hline \multicolumn{12}{|l|}{$\begin{array}{l}\text { Migrated for more than } 4 \\
\text { years but }<=5 \text { years }\end{array}$} \\
\hline 1-3 places & 89.8 & 80.7 & 53.8 & 76.1 & 72.7 & 70.5 & 20.5 & 29.5 & 12.5 & 28.4 & 88 \\
\hline $4+$ places & 75.0 & 60.5 & 28.1 & 55.8 & 50 & 80.0 & 32.5 & 27.5 & 16.7 & 43.3 & 120 \\
\hline \multicolumn{12}{|l|}{$\begin{array}{l}\text { Migrated for more than } 5 \\
\text { years }\end{array}$} \\
\hline 1-3 places & 90.0 & 85.3 & 55.9 & 82.1 & 75.8 & 63.7 & 26 & 18.4 & 9.0 & 42.6 & 223 \\
\hline $4+$ places & 83.6 & 74.6 & 42.1 & 70.6 & 62.1 & 70.4 & 35.8 & 21.5 & 16.4 & 41.2 & 517 \\
\hline \multicolumn{12}{|l|}{ Total } \\
\hline 1-3 places & 89.0 & 82.6 & 55.9 & 78.4 & 72.7 & 65.2 & 21.9 & 20.6 & 14.7 & 34.1 & 484 \\
\hline $4+$ places & 81.3 & 66.8 & 42.9 & 62.8 & 57.0 & 78.3 & 30.0 & 22.1 & 24.4 & 35.5 & 1051 \\
\hline Total \% & 83.7 & 71.7 & 45.6 & 67.7 & 62.0 & 74.2 & 27.4 & 21.6 & 21.3 & 35.0 & \\
\hline Total N & 1520 & 1515 & 703 & 1533 & 1533 & 1536 & 1536 & 1536 & 1536 & 1536 & \\
\hline
\end{tabular}

* based on less than 10 cases

' Consistent condom use computed taking the weighted average of the clients that she had sex with

${ }^{2}$ percentage of sex workers had any of the following symptoms in the last 6 months: Excessive vaginal discharge, Foul smelling discharge, Ulcers /sores in genital area, Swelling in groin area, Pain during intercourse, Itching in genital area, Pain in lower abdomen, Frequent/sometimes painful urination

${ }^{3}$ percentage refers to all those sex workers who had at least one of the STI symptoms and continue to have sex out of the total female sex workers interviewed ${ }^{4}$ percentage refers to the any of the partners beat/physically force you to have sex and not used condom during that time out of the total female sex workers interviewed ${ }^{5}$ percentage refers to the self perception of risk to HIV

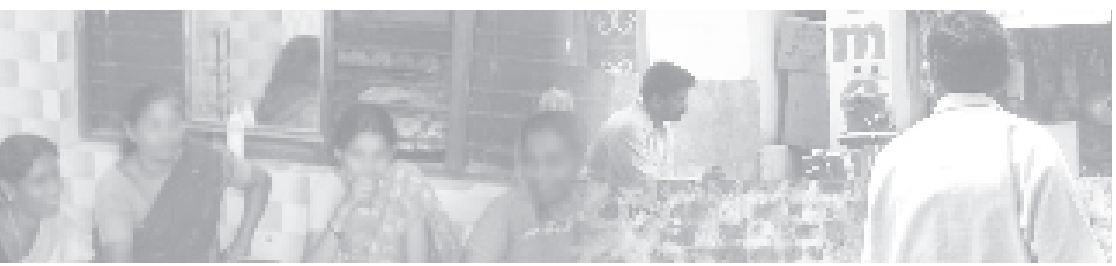


Table 16 : Per cent mobile FSWs use condoms consistently, continue to have sex even after having STI symptoms, perceive at risk for HIV

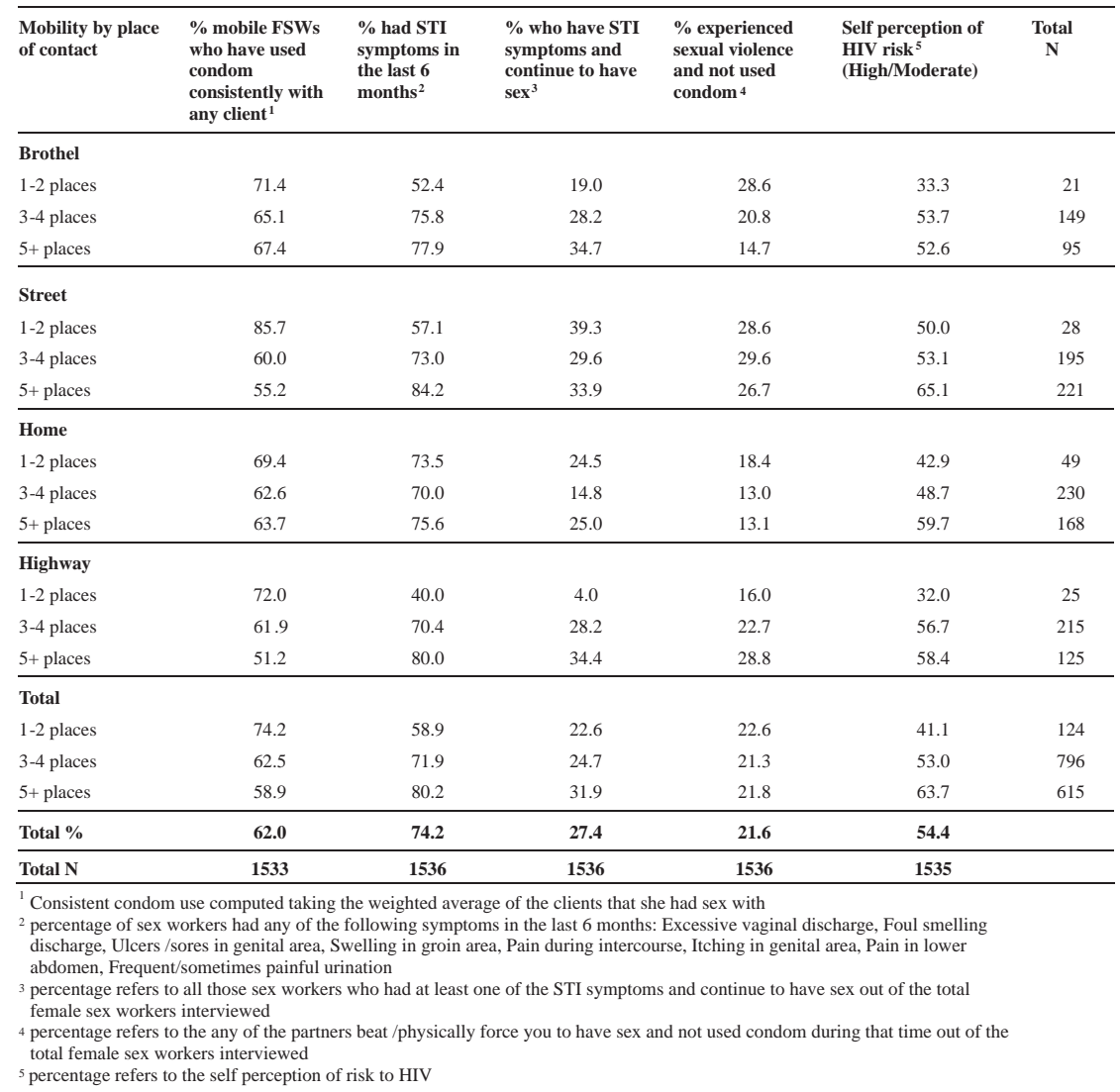




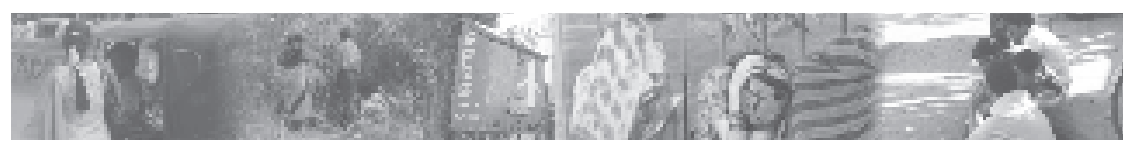

Table 17 : Places of solicitation and sex (in percent), by district

\begin{tabular}{|c|c|c|c|c|c|c|}
\hline & $\begin{array}{c}\text { East } \\
\text { Godavari }\end{array}$ & Krishna & Guntur & Hyderabad & Kurnool & $\begin{array}{c}\text { Overall } \\
\%\end{array}$ \\
\hline \multicolumn{7}{|l|}{ Places of solicitation } \\
\hline Road side & 51.6 & 68.6 & 51.4 & 56.5 & 48.2 & 54.4 \\
\hline Railway station/bus stand & 32.2 & 37.9 & 43.9 & 48.8 & 44.4 & 40.3 \\
\hline Market & 33.7 & 31.4 & 37.6 & 49.4 & 42.3 & 37.6 \\
\hline Hotels/lodge & 40.3 & 33.0 & 33.6 & 38.2 & 37.0 & 36.5 \\
\hline Own Home & 35.6 & 20.1 & 37.1 & 35.4 & 46.5 & 35.4 \\
\hline Cinema Hall & 21.0 & 29.5 & 29.3 & 36.5 & 31.7 & 28.3 \\
\hline Phone & 26.0 & 15.5 & 20.1 & 43.5 & 18.7 & 23.2 \\
\hline Brothel & 27.9 & 11.0 & 23.8 & 11.2 & 23.7 & 21.4 \\
\hline Rented room & 24.3 & 14.4 & 23.8 & 12.9 & 21.1 & 20.6 \\
\hline Dhaba & 30.3 & 29.2 & 15.0 & 12.4 & 8.8 & 20.4 \\
\hline Client's home & 8.8 & 16.7 & 20.3 & 12.9 & 20.8 & 15.8 \\
\hline Bar & 9.5 & 11.7 & 7.3 & 12.9 & 7.0 & 9.2 \\
\hline Vehicle & 11.9 & 11.7 & 7.8 & 4.7 & 4.6 & 8.7 \\
\hline Labor naka & 2.4 & 2.7 & 0.8 & 1.2 & 1.4 & 1.7 \\
\hline \multicolumn{7}{|l|}{ Places of sex } \\
\hline Rented room & 61.3 & 53.4 & 64.4 & 69.4 & 60.9 & 61.6 \\
\hline Hotels/Lodge & 60.6 & 50.8 & 60.2 & 75.9 & 61.6 & 60.7 \\
\hline Own home & 51.8 & 37.9 & 49.1 & 50.0 & 56.7 & 49.4 \\
\hline Roadside & 46.5 & 36.4 & 42.9 & 26.5 & 34.9 & 44.0 \\
\hline Client's home & 33.7 & 36.4 & 40.4 & 48.8 & 48.2 & 40.2 \\
\hline Brothel & 30.5 & 7.6 & 25.3 & 15.3 & 26.1 & 22.7 \\
\hline Dhaba & 29.8 & 22.3 & 27.3 & 7.1 & 9.2 & 21.5 \\
\hline Park/bushes & 16.2 & 19.3 & 14.8 & 11.2 & 7.0 & 13.9 \\
\hline Cinema Hall & 12.6 & 9.5 & 10.5 & 17.6 & 10.2 & 11.7 \\
\hline Market area & 11.5 & 11.4 & 9.3 & 11.8 & 10.2 & 10.7 \\
\hline Railway station/bus stand & 10.0 & 14.2 & 10.0 & 4.7 & 9.9 & 10.2 \\
\hline Vehicle & 12.2 & 13.6 & 10.5 & 1.2 & 1.1 & 8.7 \\
\hline Bar & 2.6 & 5.9 & 3 & 1.8 & 2.5 & 3.1 \\
\hline Others & 7.9 & 2.3 & 0.8 & 0.6 & 0.4 & 2.7 \\
\hline Total N & 419 & 264 & 399 & 170 & 284 & 1536 \\
\hline
\end{tabular}


Table 18 : Place of contact versus place of solicitation/sex

\begin{tabular}{|c|c|c|c|c|c|c|}
\hline \multirow{2}{*}{$\begin{array}{l}\text { Place of contact } \\
\text { (where interviewer met } \\
\text { sex worker) }\end{array}$} & \multicolumn{6}{|c|}{$\begin{array}{l}\text { Place of solicitation and sex } \\
\text { (informed by sex worker) }\end{array}$} \\
\hline & Hotel & $\begin{array}{l}\text { Railway } \\
\text { station }\end{array}$ & Dhaba & Roadside & Brothel & $\begin{array}{c}\text { Any of these } \\
\text { five }\end{array}$ \\
\hline Brothel & 70.9 & 23.0 & 18.9 & 24.5 & 79.6 & 98.9 \\
\hline Hotel/lodge & 92.3 & 53.8 & 23.1 & 84.6 & 15.4 & 100.0 \\
\hline Street & 78.2 & 73.7 & 25.4 & 87.0 & 14.2 & 98.2 \\
\hline Own home & 59.7 & 19.7 & 14.5 & 24.8 & 21.3 & 71.8 \\
\hline Highway & 63.6 & 48.9 & 69.6 & 95.7 & 11.1 & 98.2 \\
\hline
\end{tabular}

Table 19 : Major places of solicitation or sex for mobile FSWs, and different alternative scenarios for program coverage by district

\begin{tabular}{|c|c|c|c|c|c|c|}
\hline & East Godavari & Krishna & Guntur & Hyderabad & Kurnool & Total \\
\hline \multicolumn{7}{|l|}{ Place of solicitation/sex } \\
\hline Brothel & 32.9 & 12.9 & 31.8 & 17.1 & 29.6 & 26.8 \\
\hline Dhaba & 38.4 & 34.8 & 33.3 & 14.7 & 14.1 & 29.4 \\
\hline Railway station/bus stand & 32.5 & 39.8 & 47.1 & 49.4 & 46.1 & 41.9 \\
\hline Road side & 52.7 & 74.2 & 55.6 & 57.1 & 52.5 & 57.6 \\
\hline Hotels & 66.1 & 61 & 70.4 & 77.6 & 71.1 & 68.6 \\
\hline Bar & 10.5 & 12.9 & 8.8 & 13.5 & 7.4 & 10.2 \\
\hline Own Home & 55.1 & 43.2 & 58.4 & 57.6 & 64.8 & 56 \\
\hline \multicolumn{7}{|c|}{$\begin{array}{l}\text { Anticipated mobile sex workers coverage by the } \\
\text { program, if is implemented in following places }\end{array}$} \\
\hline Brothel & 32.9 & 12.9 & 31.8 & 17.1 & 29.6 & 26.8 \\
\hline Brothel + Dhaba & 59.9 & 44.7 & 51.9 & 28.2 & 37.3 & 47.5 \\
\hline $\begin{array}{l}\text { Brothel+Dhaba+ Railway sta tion/bus } \\
\text { stand }\end{array}$ & 70.9 & 68.2 & 79.2 & 60.6 & 70.8 & 71.4 \\
\hline $\begin{array}{l}\text { Brothel+Dhaba+ Railway station/bus } \\
\text { stand+roadside }\end{array}$ & 77.1 & 88.3 & 88.0 & 68.8 & 82.7 & 82.0 \\
\hline $\begin{array}{l}\text { Brothel+Dhaba+railway station or bus } \\
\text { stand+roadside+Hotels }\end{array}$ & 89.7 & 90.9 & 94.5 & 82.4 & 90.5 & 90.5 \\
\hline \multicolumn{7}{|c|}{$\begin{array}{l}\text { In any given place, No. of times sex workers would be } \\
\text { contacted by program, if the interve-netion is } \\
\text { implemented in the } 5 \text { proposed places }\end{array}$} \\
\hline 0 & 10.3 & 9.1 & 5.5 & 17.6 & 9.5 & 9.5 \\
\hline 1 & 18.9 & 14.8 & 17.5 & 16.5 & 18.3 & 17.4 \\
\hline 2 & 28.9 & 33.0 & 27.8 & 17.1 & 32.0 & 28.6 \\
\hline 3 & 27.0 & 31.8 & 34.8 & 32.4 & 30.6 & 31.1 \\
\hline 4 & 10.0 & 10.2 & 10.8 & 14.1 & 8.5 & 10.4 \\
\hline 5 & 5.0 & 1.1 & 3.5 & 2.4 & 1.1 & 2.9 \\
\hline $\begin{array}{l}\text { Average number of times, the } S W s \\
\text { will be covered by the program }\end{array}$ & 2.2 & 2.2 & 2.4 & 2.2 & 2.1 & 2.2 \\
\hline TOTAL N & 419 & 264 & 399 & 170 & 284 & 1536 \\
\hline
\end{tabular}




\section{(1) Population Council}

www.popcouncil.org 